Portland State University

PDXScholar

6-15-2020

\title{
An Investigation and Comparison of Stable Isotopes in Meteoric Waters and Groundwaters from Southern Washington
}

Emily E. Smoot

Portland State University

Follow this and additional works at: https://pdxscholar.library.pdx.edu/honorstheses

Part of the Geochemistry Commons, and the Hydrology Commons Let us know how access to this document benefits you.

\section{Recommended Citation}

Smoot, Emily E., "An Investigation and Comparison of Stable Isotopes in Meteoric Waters and Groundwaters from Southern Washington" (2020). University Honors Theses. Paper 918.

https://doi.org/10.15760/honors.940

This Thesis is brought to you for free and open access. It has been accepted for inclusion in University Honors Theses by an authorized administrator of PDXScholar. Please contact us if we can make this document more accessible: pdxscholar@pdx.edu. 


\title{
An Investigation and Comparison of Stable Isotopes in Meteoric Waters and Groundwaters from Southern Washington
}

\author{
by \\ Emily E. Smoot \\ An undergraduate honors thesis submitted in partial fulfillment of the \\ requirements for the degree of Bachelor of Science \\ in \\ University Honors \\ and \\ Geology
}

Thesis Advisor

Robert B. Perkins Ph.D.

Portland State University

2020 


\section{Table of Contents}

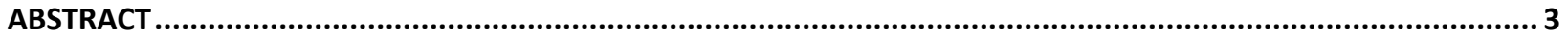

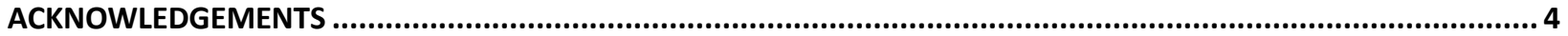

LIST OF FIGURES................................................................................................................... 5

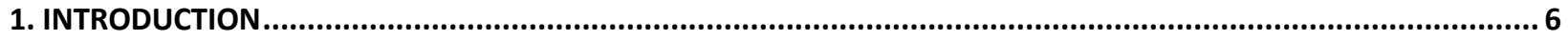

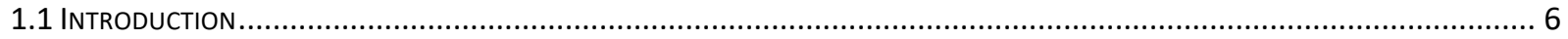

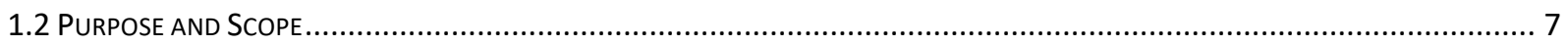

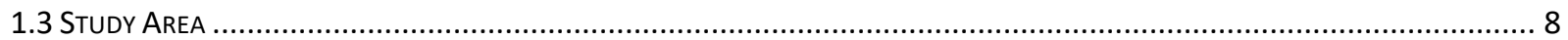

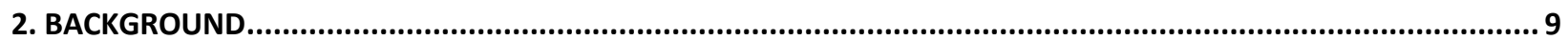

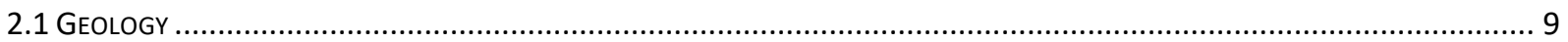

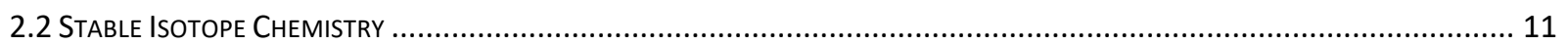

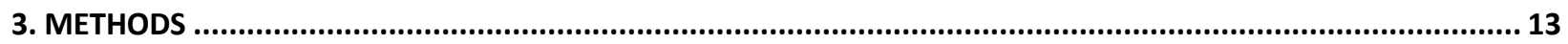

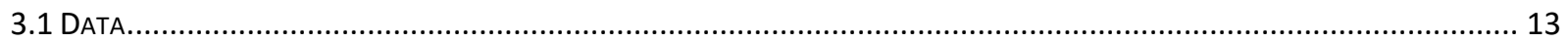

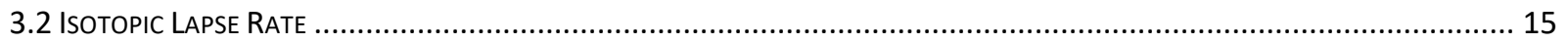

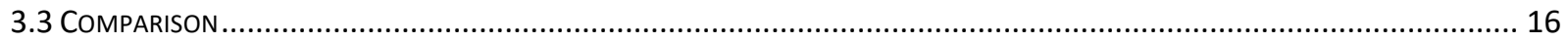

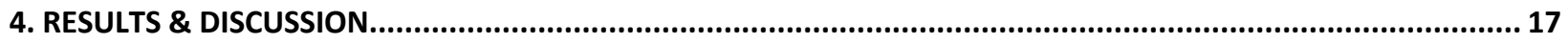

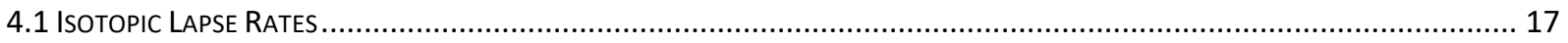

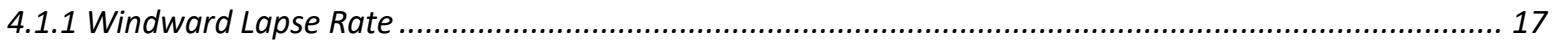

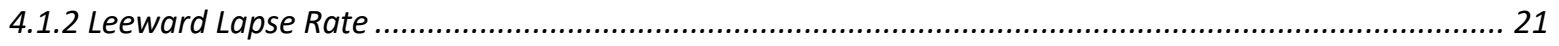

4.2 Isotopic Composition Comparison BetWeen Meteoric Waters AND GROUNDWATERS In SOUtheASTERn WASHINGTON 25

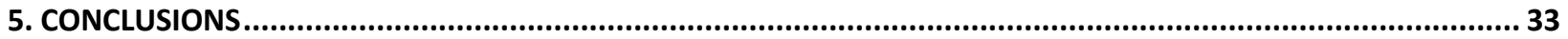

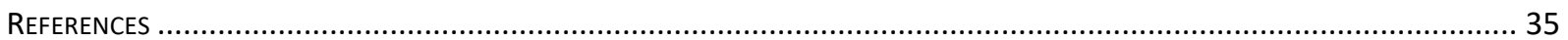

APPENDIX A. GROUNDWATER DATA USED FOR ISOTOPIC COMPARISON (VLASSOPOULOS ET AL., 2009). ................................... 38

APPENDIX B. MeteORIC WATER USED FOR COMPARISON (WATERISOTOPES, 2020; IAEA, 2020)....................................... 40

APPENDIX C. Meteoric WATERS FOR WINDWARd LAPSE RATE DETERMINATION (WATERISOTOPES, 2020; IAEA, 2020).............. 48

APPENDIX D. METEORIC WATERS USED IN THE DETERMINATION FOR THE LEEWARD LAPSE RATE (WATERISOTOPES, 2020; IAEA,

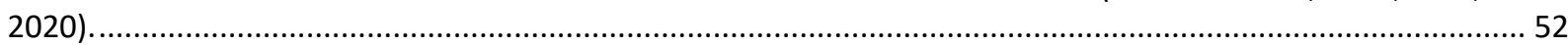




\begin{abstract}
A main source of freshwater in the Pacific Northwest is the Columbia River Basalt Group aquifer system. The semi-arid region of eastern Washington has undergone heavy groundwater depletion in recent decades due to increasing population and expanding agricultural use. Aggressive mining has resulted in drawdowns of up to 30 meters.

By using stable isotopes oxygen-eighteen $\left({ }^{18} \mathrm{O}\right)$ and deuterium (D), this study confines the timing of groundwater precipitation and proposes an explanation for why drawdowns are so significant. The isotopic composition of meteoric water is compared to groundwaters from southeast Washington. The two populations are statistically different $(p<0.001$, alpha $=0.05)$. The isotopic composition of groundwaters from the deepest wells $(<-150 \mathrm{~m} \mathrm{msl})$ are isotopically lighter than meteoric waters and not achievable by recharge under the current climate. These deep groundwaters are interpreted to have precipitated during the Last Glacial Maximum in the late Pleistocene and finished precipitating roughly $5 \mathrm{ka}$. Thus, replenishment of the aquifer cannot be expected to keep pace with extraction.

Additionally, this research examines the elevation response in the stable isotope signature of meteoric water along the $47^{\circ} \mathrm{N}$ latitude by computing three lapse rates for ${ }^{18} \mathrm{O}$ for the windward and leeward sides of the Cascade Range. The windward lapse rates are $-6.4 \% / \mathrm{km}\left(\mathrm{R}^{2}=0.72\right)$ for elevations below 1300 meters $(\mathrm{amsl})$, and $-2.5 \% \mathrm{o} / \mathrm{km}\left(\mathrm{R}^{2}=0.88\right)$ for elevations above 1300 meters (amsl). The leeward lapse rate is $12.9 \% / \mathrm{km}\left(\mathrm{R}^{2}=0.70\right)$, suggesting minimal air mass mixing over the Cascade Range during transport.
\end{abstract}




\section{Acknowledgements}

First, this thesis would not have been possible without the open access data sources of the Water Isotopes Database run by the University of Utah and the International Atomic Energy Agency's Global Network of Isotopes in Rivers. The Hydrochemistry dataset provided by Dimitri Vlassopoulos with The Columbia Basin Ground Water Management Area of Adams, Franklin, Grant, and Lincoln Counties was equally critical and appreciated.

My thanks go to Dr. Robert B. Perkins for continually pushing me to think more critically of the data, for endless patience, and for supplying me with new avenues to explore the data when I was completely stuck. Thank you for sticking through my madness to the end, especially in these unprecedented times. I have grown tremendously under your guidance.

Thank you to my family for encouragement throughout my entire undergraduate career. I could not have finished my degree without your unwavering support and motivation. I hope you all know that my ambition to succeed is inspired by you, and I hope to make you proud with my future accomplishments.

Thank you to Dr. John Bershaw for extremely useful tidbits about stable isotopes whenever I came seeking advice.

Thank you to the University Honors College for providing me with the opportunity and research education that has allowed me to complete this thesis.

Final thanks go to the Geology Department of Portland State University for providing me with not only a rock-solid education, which I will carry with me forever, but an academic family that will always stay close to my heart. 


\section{List of Figures}

Figure 1. A MAP OF WASHINGTON WITH A BLUE BOX HIGHLIGHTING THE AREA OF EXTENT FOR THE COMPARISON. THE BLACK DASHED LINES DEFINE THE STUDY AREA FOR THE LAPSE RATE DATA AND THE 47-DEGREE LATITUDE IS DENOTED BY THE RED LINE. .............. 8

Figure 2. A MAP SHOWING THE EXTENT OF THE Columbia RIVER PLATEAU (LIGHT GRAY)...................................................

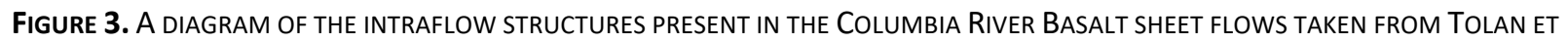
AL., 2009

Figure 4. The LOCATION OF GROUNDWATER SAMPLES (ORANGE TRIANGLES) AND METEORIC WATER SAMPLES (BLUE CIRCLES) USED FOR COMPARISON. GOLD STARS REPRESENT THE LOCATIONS OF CITIES.

FIGURE 5. WINDWARD LOW ELEVATION SAMPLES LESS THAN $1300 \mathrm{M}$ (BLUE), WINDWARD HIGH ELEVATION SAMPLES GREATER THAN 1300 $M(R E D)$ AND LEEWARD SAMPLES (BLACK). GOLD STARS REPRESENT THE LOCATIONS OF CITIES.

Figure 6. PLOT OF $\triangle \mathrm{D}$ VS $\triangle^{18}$ O SHOWING THE LOCAL METEORIC WATER LINE (LMWL; BLUE SOLID LINE) FOR THE WINDWARD SIDE OF THE CASCADE RANGE AT A LATITUdE OF $47 \pm 0.5^{\circ}$ AS DETERMINED FROM METEORIC WATER SAMPLES (BLUE DOTS). THE RED X'S DENOTE METEORIC WATER SAMPLES THAT HAD DEUTERIUM EXCESS VALUES ONE STANDARD DEVIATION OR MORE LESS THAN THE AVERAGE, LIKELY REFLECTING EVAPORATION. THE BLACK DASHED LINE REPRESENTS THE GMWL (CRAIG, 1961).

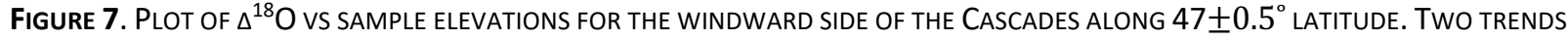
ARE APPARENT; THE RED POINTS AND LINE ARE FROM SAMPLES COLLECTED AT GREATER THAN 1300 METERS (AMSL) ELEVATION, AND BLUE POINTS ARE FROM SAMPLES COLLECTED BELOW 1300 METERS ELEVATION..

Figure 8. $\triangle$ D VS SAMPLE ElEVATIONS FOR THE WINDWARD SIDE OF THE CASCADES ALONG $47 \pm 0.5^{\circ}$ LATITUDE. RED DIAMONDS ARE FROM SAMPLES COLLECTED AT ELEVATIONS GREATER THAN 1300 METERS (AMSL), AND BLUE DIAMONDS ARE FROM SAMPLES COLLECTED BELOW 1300 METERS.

Figure 9. GRAPH OF THE LEEWARD LMWL (BLACK), WITH HEAVILY EVAPORATED SAMPLES (RED) AND THE GMWL FOR REFERENCE AS A

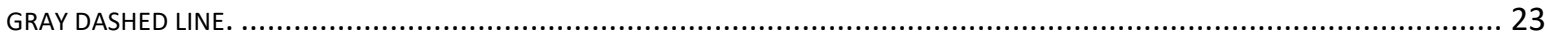

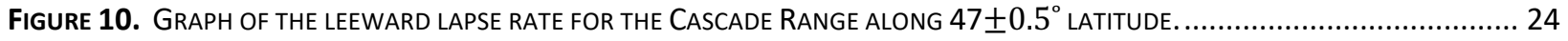

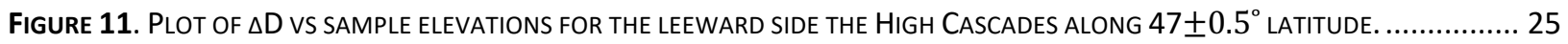

Figure 12. GRAPH OF $\triangle \mathrm{D}$ VS $\Delta^{18} \mathrm{O}$ FOR THE METEORIC WATER (BLUE) AND GROUNDWATER SAMPLES (ORANGE). THE METEORIC WATER SAMPLES PROVIDE THE LMWL FOR THE REGION WHICH IS COMPARED TO THE GMWL (GRAY DASHED LINE) (CRAIG, 1960). RED XS DENOTE METEORIC WATER SAMPLES THAT HAD D-INDEXES ONE STANDARD DEVIATION OR MORE LESS THAN THE AVERAGE AND WERE

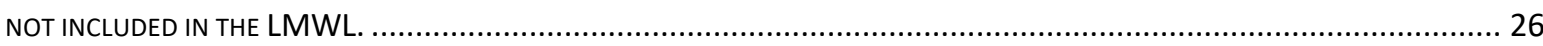

FIGURE 13A. BOX AND WHISKER PLOTS COMPARING METEORIC WATER AND GROUNDWATER $\triangle$ D SAMPLES. THE LIGHT BLUE BOX IS

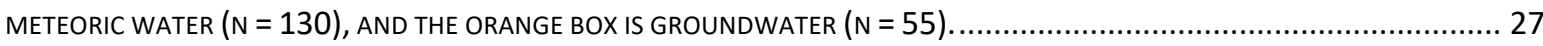

FIgURE 13B. BOX AND WHISKER PLOTS COMPARING METEORIC WATER AND GROUND WATER $\Delta^{18} \mathrm{O}$ SAMPLES. THE LIGHT BLUE BOX IS METEORIC WATER $(N=131)$ AND THE ORANGE BOX IS GROUNDWATER $(N=72)$.

FIGURE 14A. A GRAPH SHOWING THE $\triangle$ D RATIO AGAINST TIME FOR FIVE RIVERS IN SE WA. THE BLUE DIAMONDS REPRESENT THE COLUMBIA RIVER, YELLOW XS ARE THE SNAKE RIVER, GREEN TRIANGLES ARE THE OKANOGAN RIVER, BLACK CIRCLES ARE THE

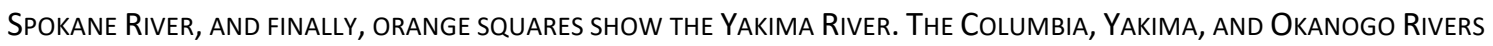
SHOW A FAIRLY CONSISTENT SEASONAL TRANSITION OF DECREASING ISOTOPIC COMPOSITION THROUGH THE FALL AND END OF WINTER AND THEN AN INCREASING ISOTOPIC COMPOSITION IN LATE SPRING AND SUMMER.

FigURE 14B. GRAPH DISPLAYING THE $\triangle{ }^{18}$ O RATIO AGAINST TIME FOR FIVE RIVERS IN SE WA IN FIGURE 14A. A SIMILAR SEASONAL TREND IS PRESENT DISTINCTLY IN TWO OF THE FIVE RIVERS.

Figure 15A. Plot of $\triangle$ D AGAinst Well bottom EleVAtion In METERS to MEAN SEA LEVEL. BLACK DASHED LINES REPRESENT PROPOSED CUTOFFS AT -150 M AND $500 \mathrm{M}$.

Figure 15B. GRAPH OF $\triangle 180$ AgAinst WELL BOTTOM ELEVATION IN METERS TO MEAN SEA LEVEL (MSL). A SLIGHT INCREASING TREND CAN BE INFERRED. BLACK DASHED LINES REPRESENT PROPOSED CUTOFFS AT -150 M AND $500 \mathrm{M}$. 


\section{Introduction}

\subsection{Introduction}

Groundwater in the Columbia River Basalt Group (CRBG) aquifers represents a substantial source of the Pacific Northwest's fresh water supply (Tolan et al., 2009; Vaccaro, 1999). Over time, growing demand and heavy pumping have resulted in significant declines in groundwater levels, particularly in the more arid regions east of the Cascade Mountains where "drawdowns" of nearly thirty meters have been reported (Papadopoulos \& Associates, 2012). This amount of well drawdown is substantial, and further declines are projected as groundwater demands increase in the future. The current rate at which wells are being pumped is unsustainable, as the aquifers are not replenishing to keep up with the demand (Papadopoulos \& Associates, 2012; Lum et al., 1990; Larson et al., 2000).

The issue of aquifer replenishment could be due to several factors, including excess pumping, changing climate regimes, and/or long recharge rates (Papadopoulos \& Associates, 2012; Gat, 1996; Vaccaro, 1999). Determining which of these possibilities is the most impactful will influence water usage practices aimed at avoiding future supply deficiencies. Water will always be a necessity, and it is important to expand our knowledge of our natural storage systems as much as possible.

The isotopic chemistry of waters provides an important tool for understanding the complicated dynamics of source waters, aquifer recharge and flow. One important method is the determination and modeling of isotopic lapse rates, the relationship between elevation and isotopic composition of meteoric waters. Currently, there are two lapse rates presented for the state of Washington, one for the Olympic Peninsula (Sharp et al., 1960) and one that combines data along both the $48^{\circ}$ and $45^{\circ}$ north latitudes (Bershaw et al., 2020). This leaves a rather wide gap ( $3^{\circ}$ of latitude) in the data across the state of Washington and 
limits our understanding of water isotope chemistry in this dynamic region. Solidifying this relationship allows for the exploration of how precipitation is changing as vapor masses travel over our continent. These changing masses have a trickle-down effect; the changing composition of the air mass affects the isotopic composition of meteoric water bodies, and the aquifers which they replenish. Changing isotopic composition is a way one can narrow the source waters of an aquifer and determine if these waters may have been precipitated under a different climate regime. Thus, the isotopic composition becomes an intimate component of the hydrology of the area.

\subsection{Purpose and Scope}

The first goal of my study is to better understand the recharge dynamics of the CRBG aquifer system in southcentral Washington. Specifically, I will compare the stable isotopic signatures of CRBG groundwaters with those of modern meteoric water by examining deuterium (D) and oxygen-eighteen $\left({ }^{18} \mathrm{O}\right)$ ratios. I hypothesize that the groundwaters will have lighter isotopic signatures than the meteoric waters. The delta $(\delta)$ values for oxygen-eighteen and deuterium for groundwaters will be more negative than the corresponding values of modern meteoric waters because the fractionation of the isotopes occurred at a lower temperature, suggesting that the groundwater being withdrawn today began precipitating during a colder climate, likely more than $11.6 \mathrm{ka}$, prior to the start of the Holocene epoch (Larson, et al., 2000; Douglas et. al., 2009; Brown et al., 2011).

The implications of this study, if the primary hypothesis is supported, would be that much of the groundwater currently pumped from CRBG aquifers beneath southcentral Washington was precipitated during the Pleistocene. Because of the change in climatic conditions, (1) recharge to these aquifers cannot be modeled using modern precipitation measurements nor forecasts and (2) aquifer replenishment cannot be expected to keep pace with groundwater extraction. 
The second goal of this study is to add to the existing knowledge base of the use of stable isotopes in hydrology for Washington state. The study presents six isotopic lapse rates, three for ${ }^{18} \mathrm{O}$ and three for $\mathrm{D}$, which expand the current knowledge base of stable isotopes in precipitation for the region. The lapse rates are calculated for the $47^{\circ} \mathrm{N}$ latitude for both the windward and leeward sides of the High Cascades. This latitude was chosen both because it bisects the study area for which groundwater data was obtained (Figure 1) and helps fill in the data gap for windward lapse rates in the Pacific Northwest region calculated by Bershaw et al., (2020) for the $48^{\circ}$ and $45^{\circ}$ latitudes and Sharp et al., (1960) for the Olympic Peninsula.

\subsection{Study Area}
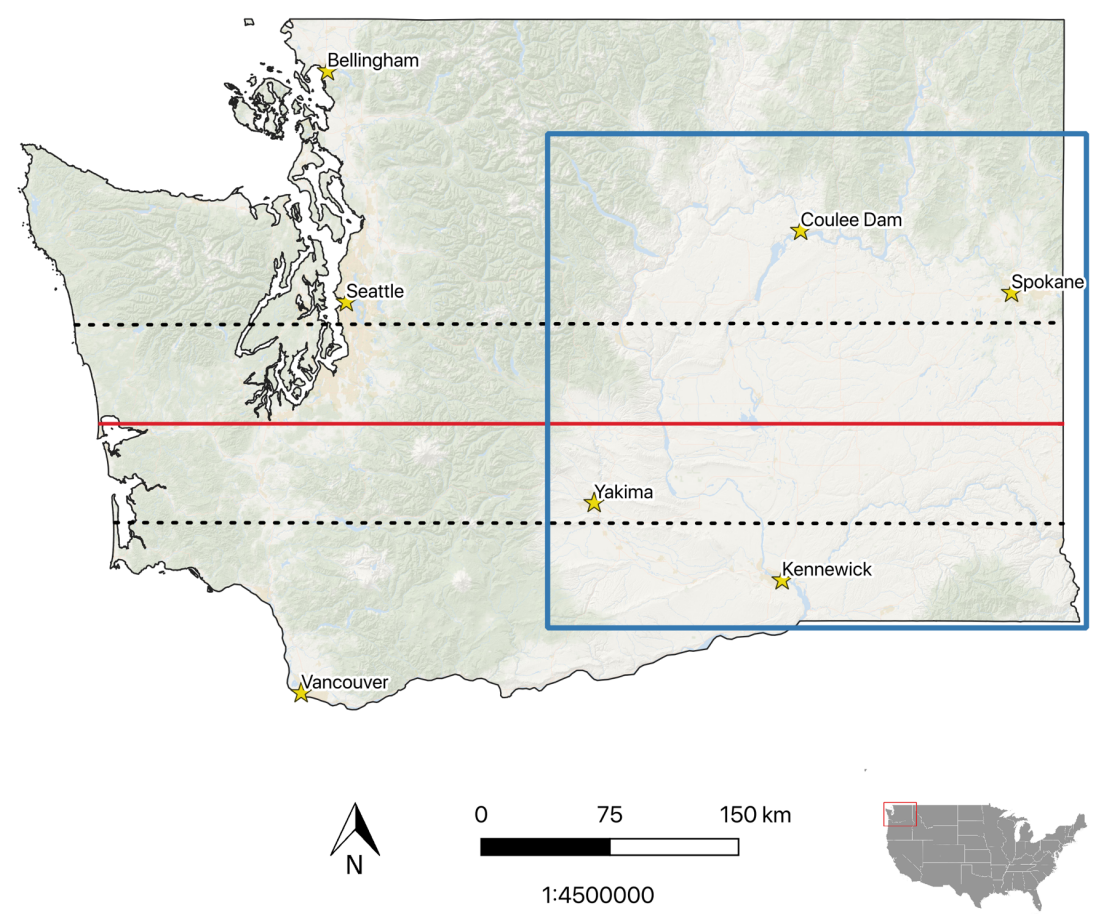

Figure 1. A map of Washington with a blue box highlighting the area of extent for the comparison. The black dashed lines define the study area for the lapse rate data and the 47-degree latitude is denoted by the red line. 


\section{Background}

\subsection{Geology}

The Columbia River Plateau (Figure 2) is underlain by the Columbia River Basalt Group (CRBG), which covers a massive area in the Pacific Northwest, extending from Idaho to the Pacific Ocean (Reidel \& Tolan, 2013). The multi-layered volcanic rocks of the CRBG grace the Pacific Northwest with many unique features, including the high walls and waterfalls of the Columbia River Gorge.

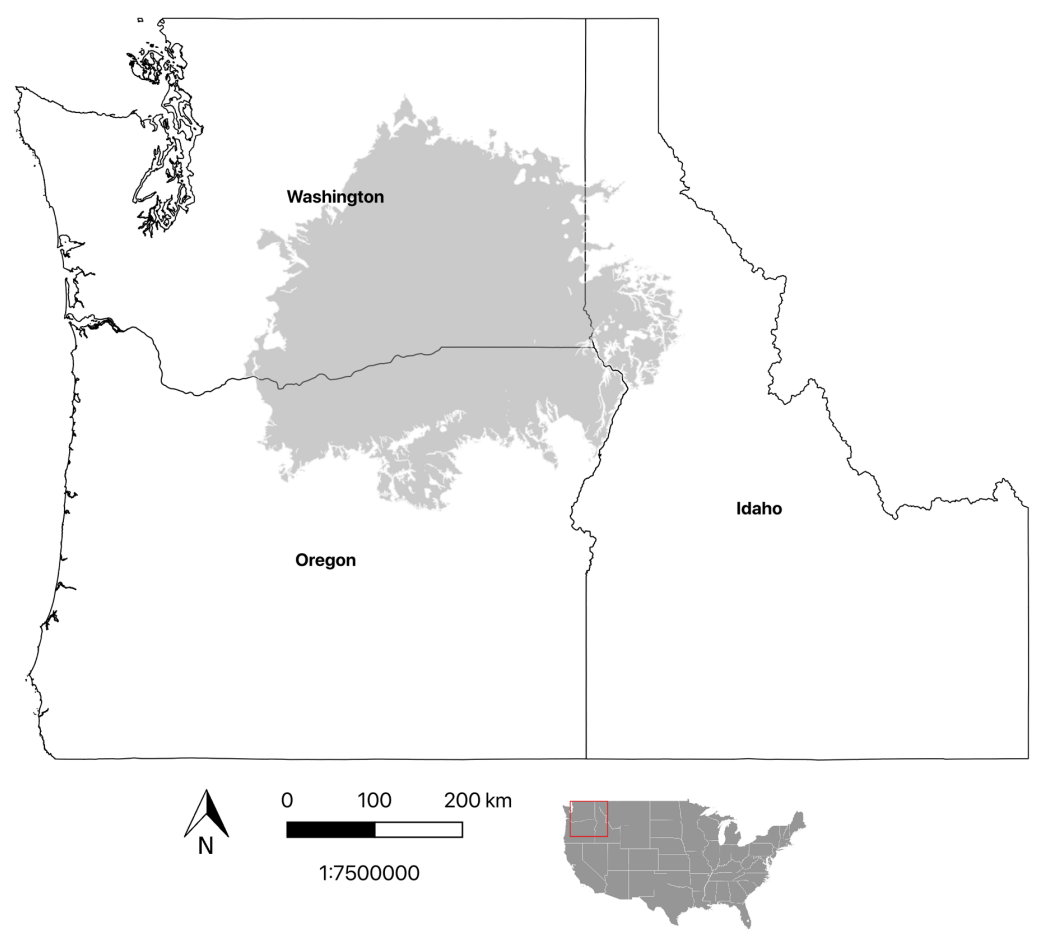

Figure 2. A map showing the extent of the Columbia River Plateau (light gray).

The CRBG represent stacks of individual lava flows that poured out of fissures in eastern Oregon, Washington, and western Idaho five to seventeen million years ago (Reidel \& Tolan, 2013; Vaccaro, 1999). As flows of lava traveled along the surface, the tops began to cool and 
solidify; however, this outer crust would be broken up by the continued movement of the still fluid interior, forming a broken, rubbly flow top (Tolan et al., 2009; Figure 3). The porosity resulting from this process, known as brecciation, is augmented by vesicles formed by degassing of the lava (Tolan et al., 2009). The porosity in the brecciated flows allows for the storage and movement of groundwater. Because these zones occur between individual lava flows, they are known as the "interflow zones" (Tolan et al., 2009; Figure 3). These interflow zones store the majority of the groundwater for the study area and the Pacific Northwest (Vlassopoulos et al., 2009; Tolan et al., 2009; Figure 3).

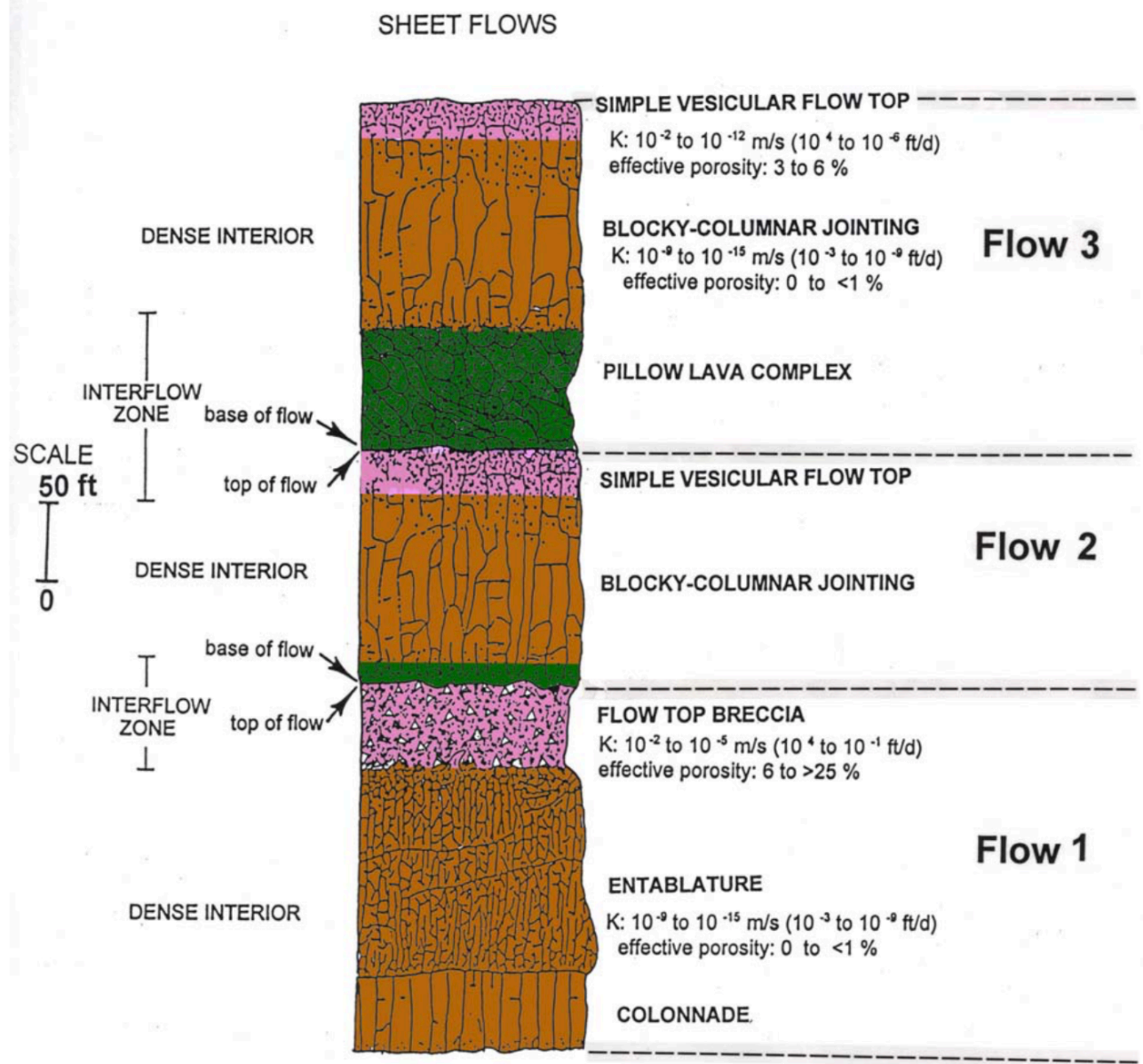

Figure 3. A diagram of the intraflow structures present in the Columbia River Basalt sheet flows taken from Tolan et al., 2009. 


\subsection{Stable Isotope Chemistry}

An important method for constraining groundwater recharge conditions is to use stable isotopes. A common method used is Carbon fourteen $\left(\mathrm{C}^{14}\right)$ dating. The age of groundwaters within the study area has been constrained using $\mathrm{C}^{14}$ age dating and deep groundwaters are thought to be on the order of thousands of years old to tens of thousands of years old (Douglas et al., 2009; Brown et al., 2011). This dating method constrains the amount of time the waters have been out of contact with the atmospheric carbon and provides one with an estimate of the date the water could have been precipitated; however, $\mathrm{C}^{14}$ dating can have its uncertainties. Many different types of reactions occur in groundwater that can affect the accuracy of $\mathrm{C}^{14}$ techniques. For example, the weathering of feldspars in the surrounding rock can cause the precipitation of calcium carbonate $\left(\mathrm{CaCO}_{3}\right)$. This process of precipitation involves the fractionation of carbon in the system affecting the amount of $\mathrm{C}^{14}$. Prevalently used models for $\mathrm{C}^{14}$ dating do not often account for these types of reactions, giving any calculated result an inherent uncertainty (Pearson \& Hanshaw, 1970; Plummer \& Glynn, 1992). Thus, an alternative method for constraining groundwater recharge conditions is using stable isotopes, which are often unaffected by waterrock interactions.

Stable isotopes do not spontaneously decay like their radioactive counterparts. Stable isotope composition is affected by numerous factors such as evaporation, precipitation, temperature, and elevation (Clark \& Fritz, 1999; Clark, 2015). The isotopes fractionate; isotope fractionation is the partitioning of heavy and light isotopes between two phases in a natural system. One example is ${ }^{18} \mathrm{O}$ and ${ }^{16} \mathrm{O}$ in the liquid and vapor phases of water (Urey, 1947; Clark \& Fritz, 1999). Energy is needed to separate isotopes from their ideal interatomic distance. The heavy isotopes have a stronger bond and require a greater amount of energy to dissociate than a light isotope. Consequently, the heavy isotopic species are typically partitioned into the more 
condensed phases, such as into the liquid phase in vapor-liquid reactions, because of this greater bond strength (Clark \& Fritz, 1999; Clark, 2015). These fractionation events occur during evaporation and precipitation and when vapors travel inland over continents for long periods of time or experience a change in elevation when traveling over topography.

Fractionation is heavily influenced by temperature because it is a thermodynamic reaction (Clark \& Fritz, 1999). At lower eustatic temperatures, the oceans tend to have heavier isotopic values while precipitation and the ice sheets experience lighter values because the heavier bonds are more difficult to break and fewer leave their initial liquid state (Clark \& Fritz, 1999). Similarly, increasing elevation causes isotopic composition to become lighter or more negative due to the drop in atmospheric temperature with increased elevation.

Because of fractionation, stable isotopes make good proxies for paleoclimates and paleoelevations (Poage \& Chamberlin, 2001; Garzione et al., 2000; Clark, 2015). By evaluating the isotopic composition of the groundwater for a region, one can determine if the recharge waters for a system were sourced from high or low elevations or deposited during climates differing from the present (Clark \& Fritz, 1999; Poage \& Chamberlin, 2001; Larson et al., 2000; Lecher et al., 2018).

Due to the fractionation processes described, ${ }^{18} \mathrm{O}$ and $\mathrm{D}$ in precipitation covary is a predictable manner. At the global scale, this covariance results in the Global Meteoric Water Line (GMWL) (Craig, 1961). The GMWL is described by the following equation:

$$
\delta D=8 \delta^{18} O+10
$$

While the GMWL describes the variation in the stable isotope signature of meteoric waters at the global scale, isotopic variation within specific regions are best described by the Local Meteoric Water Line (LMWL). This LMWL is created by plotting the measured ratios of $\mathrm{D}$ and ${ }^{18} \mathrm{O}$ from a specific region. Thus, providing a benchmark or normal for the isotopic composition of the 
area. The LMWL of a region can then be compared to the GMWL to determine if certain processes are more prevalent than others such as evaporation and equilibrium fractionation (Clark and Fritz, 1999).

\section{Methods}

\subsection{Data}

The data used in this research was collected from three main sources. The first source is a hydrochemistry data set from Vlassopoulos et al. (2009), which includes stable isotope ratios for seventy-two groundwater samples collected from southcentral Washington state, between $-120.0^{\circ}$ and $-117.5^{\circ}$ longitude and $48.0^{\circ}$ and $46.0^{\circ} \mathrm{N}$ latitude

(Figure 4). Surface water data was used instead of direct precipitation for both the determination of lapse rates and the comparison with groundwater data because the surface waters effectively average precipitation values overtime. Additionally, there was a lack of direct precipitation data within the study area and very few sites were readily available for retrieval. The meteoric water data $(n=131)$ retrieved for comparison with the groundwater data came from the WaterIsotopes database and the Global Network of Isotopes in Rivers (GNIR) database (IAEA, 2020). The data sites were queried for river, stream and lake samples located between $46.0^{\circ}$ and $48.5^{\circ} \mathrm{N}$ latitude and $-121.0^{\circ}$ and $-117.0^{\circ}$ longitude (Figure 4). 

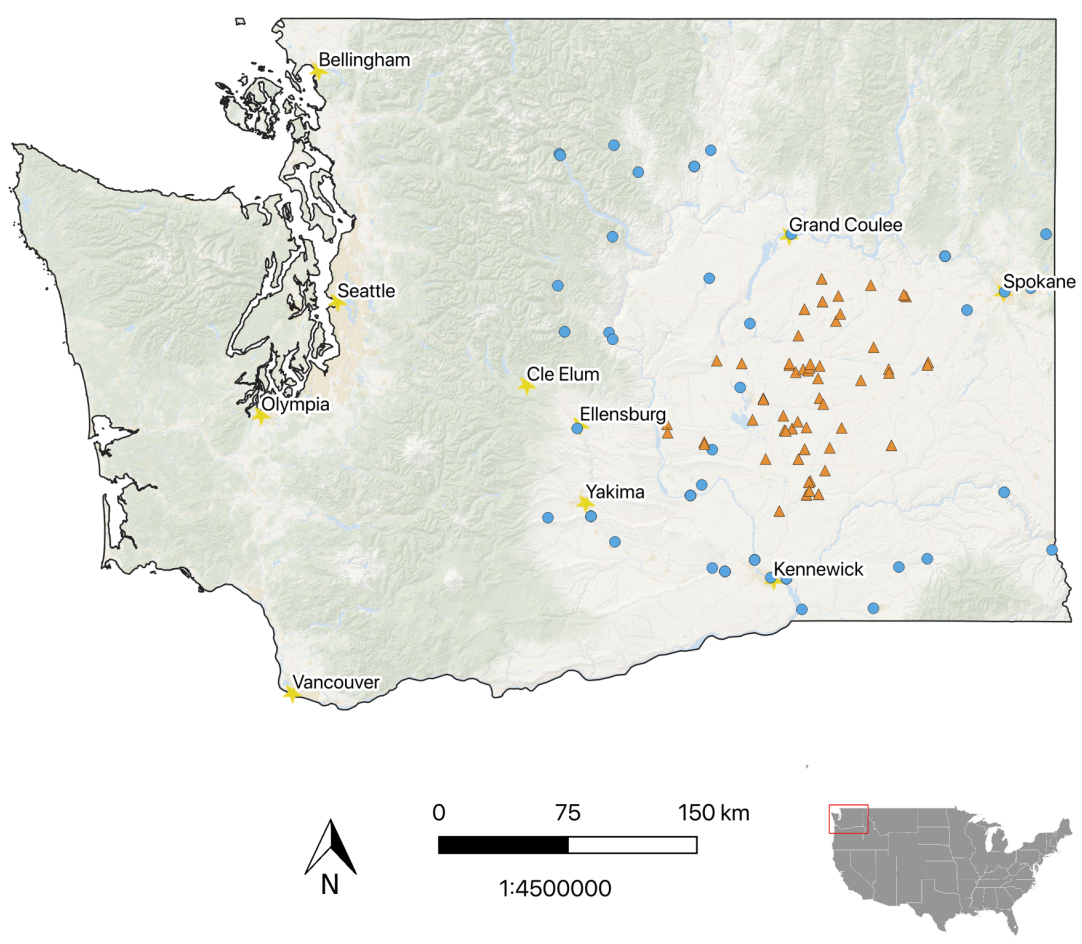

Figure 4. The location of groundwater samples (orange triangles) and Meteoric water samples (blue circles) used for comparison. Gold stars represent the locations of cities.

Similarly, meteoric water data for determining lapse rates $(\mathrm{n}=113)$ was obtained from the WaterIsotope Database (WaterIsotopes, 2020) for rivers, streams and lakes located between $46.5^{\circ}$ and $47.5^{\circ} \mathrm{N}$ latitude and $-124.0^{\circ}$ and $-117.0^{\circ}$ longitude (Figure 5).

A comparable query with the same coordinate boundaries was used on the data site for time series data from GNIR (IAEA, 2020). Any duplicate data from GNIR was removed before combining the two datasets. Both retrieved datasets had incomplete elevation measurements. New elevations for the sample sites were determined based on existing GPS coordinates and the corresponding surface elevations obtained from Google Earth Pro. 

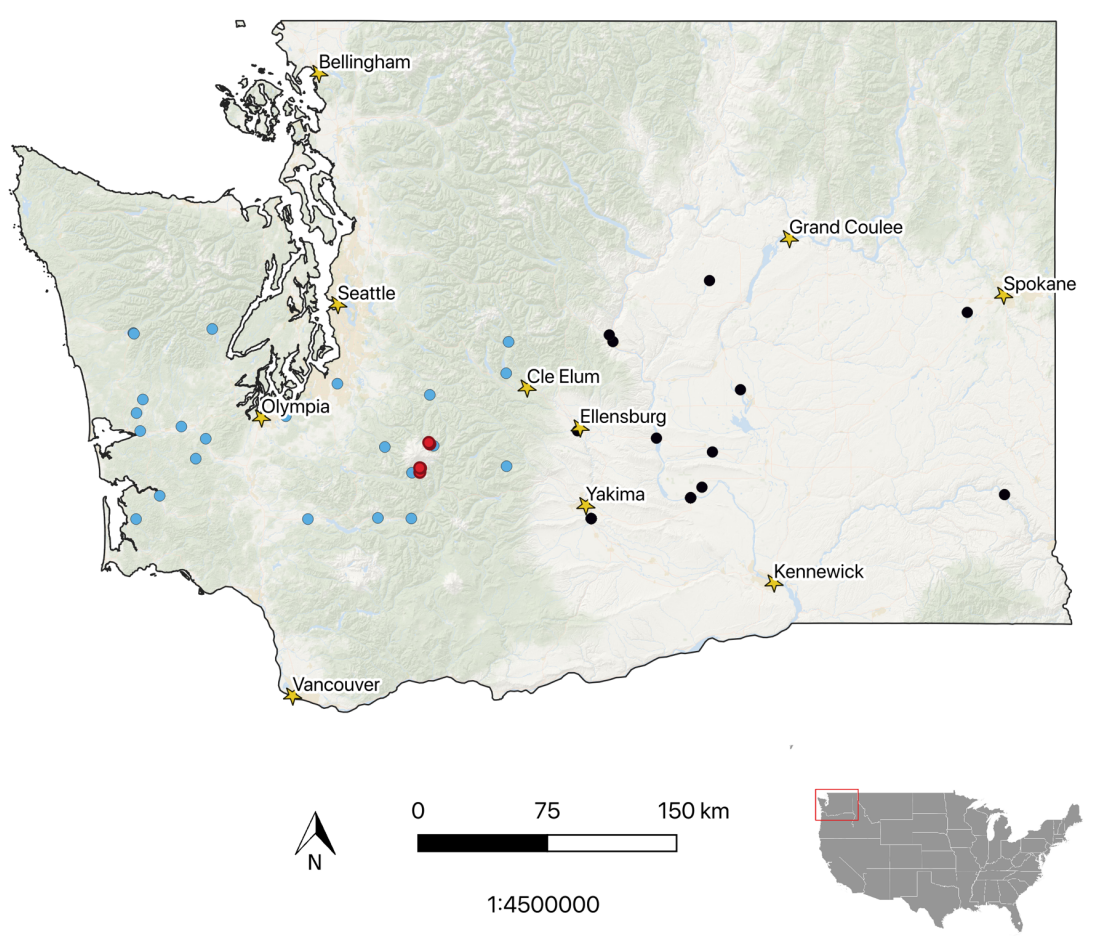

Figure 5. Windward low elevation samples less than $1300 \mathrm{~m}$ (blue), windward high elevation samples greater than $1300 \mathrm{~m}(\mathrm{red})$ and leeward samples (black). Gold stars represent the locations of cities.

All of the isotopic data used in the study are reported in delta $(\delta)$ notation with units of per mille (\%). The samples have been reported relative to the Vienna Standard Ocean Water (VSMOW) for ${ }^{18} \mathrm{O}$ and $\mathrm{D}$. These sample values were calculated using the following equation or an equivalent, where ${ }^{18} \mathrm{O}$ is the heavy oxygen isotope and ${ }^{16} \mathrm{O}$ is the light oxygen isotope.

$$
\delta^{18} O=\left(\frac{\left({ }^{18} O /{ }^{16} O\right)_{\text {sample }}}{\left({ }^{18} O /{ }^{16} O\right)_{\text {reference }}}-1\right) \cdot 1000 \% \text { VSMOW }
$$

\subsection{Isotopic Lapse Rate}

The windward and leeward samples were split on the $-121.0^{\circ}$ longitude line as this corresponds with the eastern boundary of the Cascades Range and groups the high elevations together. To account for evaporation effects on the isotopic compositions of the 
meteoric waters, the local meteoric water lines (LMWL, or trendline of local meteoric water data on a $\delta \mathrm{D}$ versus $\delta^{18} \mathrm{O}$ plot $)$ for both the windward $(\mathrm{n}=67)$ and leeward samples $(n=46)$ were compared to the GMWL established by Craig (1961) to be,

$$
\delta D=8 \delta^{18} O+10
$$

The deuterium excess or d-index $(d)$ was computed for each of the samples using following equation (Dansgaard, 1964):

$$
d=\delta D-8 \delta^{18} O
$$

Once the deuterium excess was computed for each of the samples, a mean and standard deviation were computed. Samples were excluded from the LMWL and lapse rate calculations if they were one or more standard deviations less than the mean. These points were removed from the calculations because the low or negative deuterium excess suggests evaporation. The selected samples were then graphed against their corresponding sample elevations. If samples were taken at the same location over a period of time these samples were averaged before plotting. The slope of the linear trendline then supplies the lapse rate for the samples (Poage \& Chamberlin, 2001; Garizone et al., 2000).

\subsection{Comparison}

The analysis for the comparison was completed using $\mathrm{R}$ and Excel. The analytic techniques used were the Mann-Whitney-U test, box and whisker plots, and linear regressions. These tools were used to determine the statistical significance of the difference between the meteoric water and the groundwater samples. Additionally, the isotopic values of the samples from the meteoric water population were plotted against time when measurements were taken over an extended interval of time of one month or greater. These plots were then used to determine any seasonal variance of the isotope ratios within the rivers. The isotopic value ranges for winter precipitation, November to 
March, were compared to the groundwaters at the shallowest depths that could potentially be influenced by seasonality. Statistical significance for the groundwater versus well bottom elevation plots was determined with linear regressions.

\section{Results \& Discussion}

\subsection{Isotopic Lapse Rates}

\subsubsection{Windward Lapse Rate}

A majority of the data from samples collected on the windward side of the Cascade Range closely follow the GMWL; however, the LMWL has a lower y-intercept of $7.44 \%$ for $\delta \mathrm{D}$ (Figure 6). Eight samples with the lowest deuterium excess values followed a trend with a lower slope and were deemed to have been impacted by evaporation; these samples (red x's in Figure 6) were not used in calculation of the lapse rate.

The lapse rate for the windward side of the Cascade Range is showing to be roughly $-6.4 \% / \mathrm{km}$ for mid and low elevations $(<1300 \mathrm{~m})$, and $-2.5 \% / \mathrm{km}$ for high elevation samples, greater then $1300 \mathrm{~m}$ (Figure 7). The $\mathrm{R}^{2}$ value for the relationship between ${ }^{18} \mathrm{O}$ ratios and mid to low elevations is 0.72 , while the $\mathrm{R}^{2}$ equals 0.88 for high elevations (Figure 7).

There are several possibilities for why these samples do not fit a linear trend better. Of these, the dominant issues are the sampling elevation relative to the headwaters for a stream and the influence of snow sublimation on the isotopic composition of the meteoric waters. The first issue of excluding the headwaters is because many of the samples were collected from easily accessible locations. In the case of the Puyallup River, its sample elevation of seven meters is drastically lower than the majority of its path for which elevation peaks at roughly 2500 meters (Dzurisin et al., 1983). The Puyallup River plotted with its sample elevation lands almost directly on the y-axis and with a $\delta^{18} \mathrm{O}$ of $-12.5 \%$. If the sample were to be plotted with its headwater 
elevation, roughly 2500 meters for the Puyallup Glacier, it would lie closely along the trendline for the high elevation samples (Dzurisin et al., 1983). Doing this with some of the other samples would produce a similar result and plot the points closer to the current trendlines, thus, raising the $\mathrm{R}^{2}$ value in the process.

The second issue that may be affecting the fit of the data to a linear trendline is due to potential snow sublimation. The sublimation of snow is suggested to enrich the isotopic composition of the snowpack and the resulting meltwaters (Lecher \& Neimi, 2012). Since the western United States is snow dominated (Barnett et al., 2005), it is reasonable to assume that changes in snowpack isotope chemistry will substantially alter the stream water isotopic compositions. This enrichment due to sublimation will result in higher $\delta^{18} \mathrm{O}$ values than anticipated for the sample elevations.

The calculated lapse rate values compare well to the lapse rates previously reported for Washington and global mountain ranges. The mid- to low-elevation lapse rate of $-6.4 \% / \mathrm{km}$ compares well to the Olympic Peninsula lapse rate of $-5.1 \% / \mathrm{km}\left(\mathrm{R}^{2}=0.89\right)$ (Sharp et al., 1960), and the high elevation samples compare very well to the combined lapse rate for the Coast Range and High Cascades at latitudes of $45.0^{\circ}$ and $48.0^{\circ}$ respectively, of $-3.1 \% / \mathrm{km}$ $\left(\mathrm{R}^{2}=0.70\right)$ (Bershaw, et al., 2020). Additionally, the high elevation lapse rate of $-2.5 \% / \mathrm{km}$ agrees with the global lapse rate for mountain ranges of $-2.8 \% / \mathrm{km}$ (Poage \& Chamberlin, 2001). Additionally, similar trends are present when $\delta \mathrm{D}$ is plotted against the sampled elevation. These trends show an inverse relationship between increasing sample elevation and decreasing $\delta \mathrm{D}$ values (Figure 8). Similar patterns for D have been reported by Smith et al., (1978) in eastern California, where $\delta \mathrm{D}$ became more depleted as precipitation was sampled at higher elevations. 


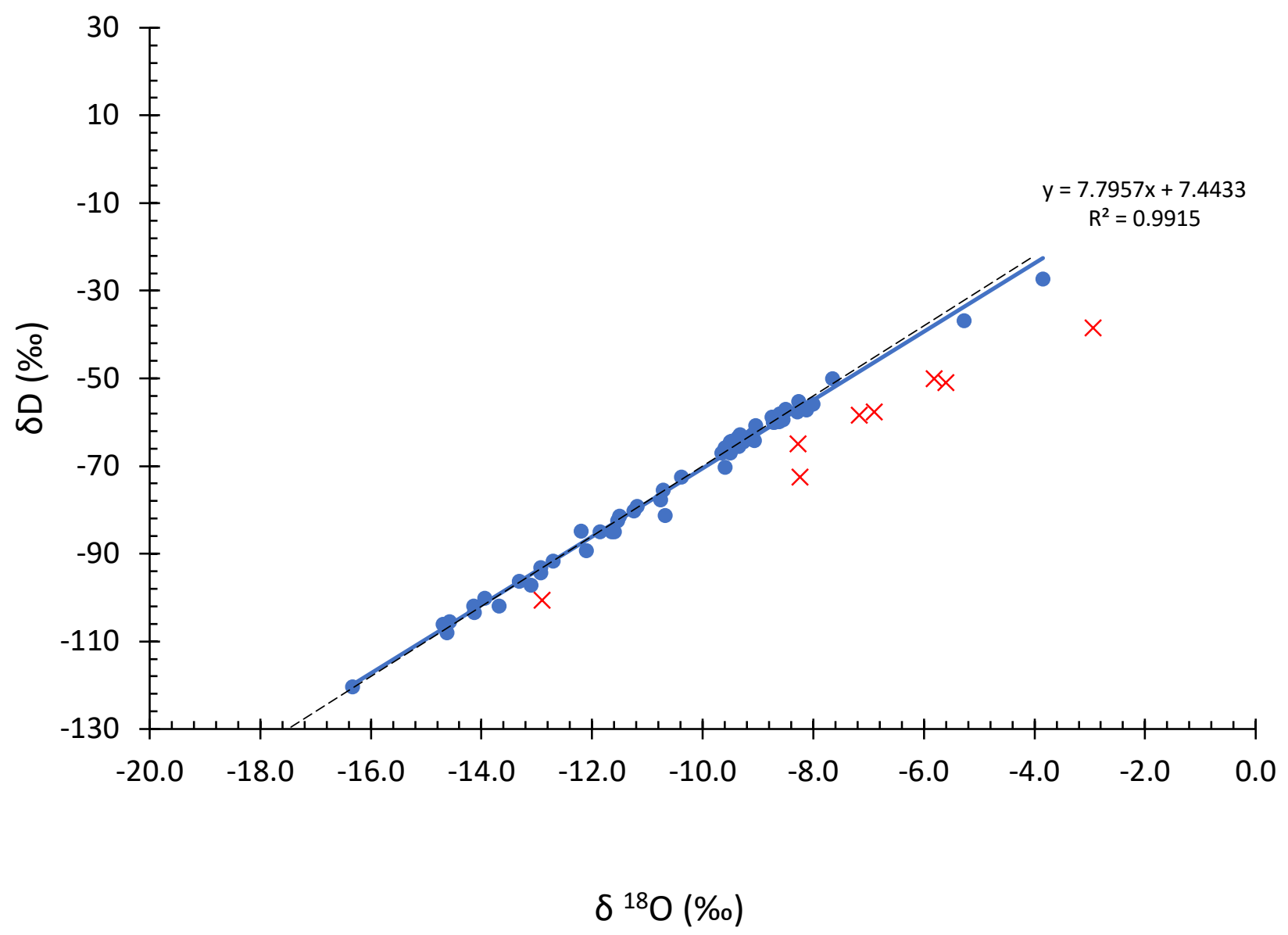

Figure 6. Plot of $\delta D$ vs $\delta^{18} O$ showing the Local Meteoric Water Line (LMWL; blue solid line) for the windward side of the Cascade Range at a latitude of $47 \pm 0.5^{\circ}$ as determined from meteoric water samples (blue dots). The red $X$ 's denote meteoric water samples that had deuterium excess values one standard deviation or more less than the average, likely reflecting evaporation. The black dashed line represents the GMWL (Craig, 1961). 


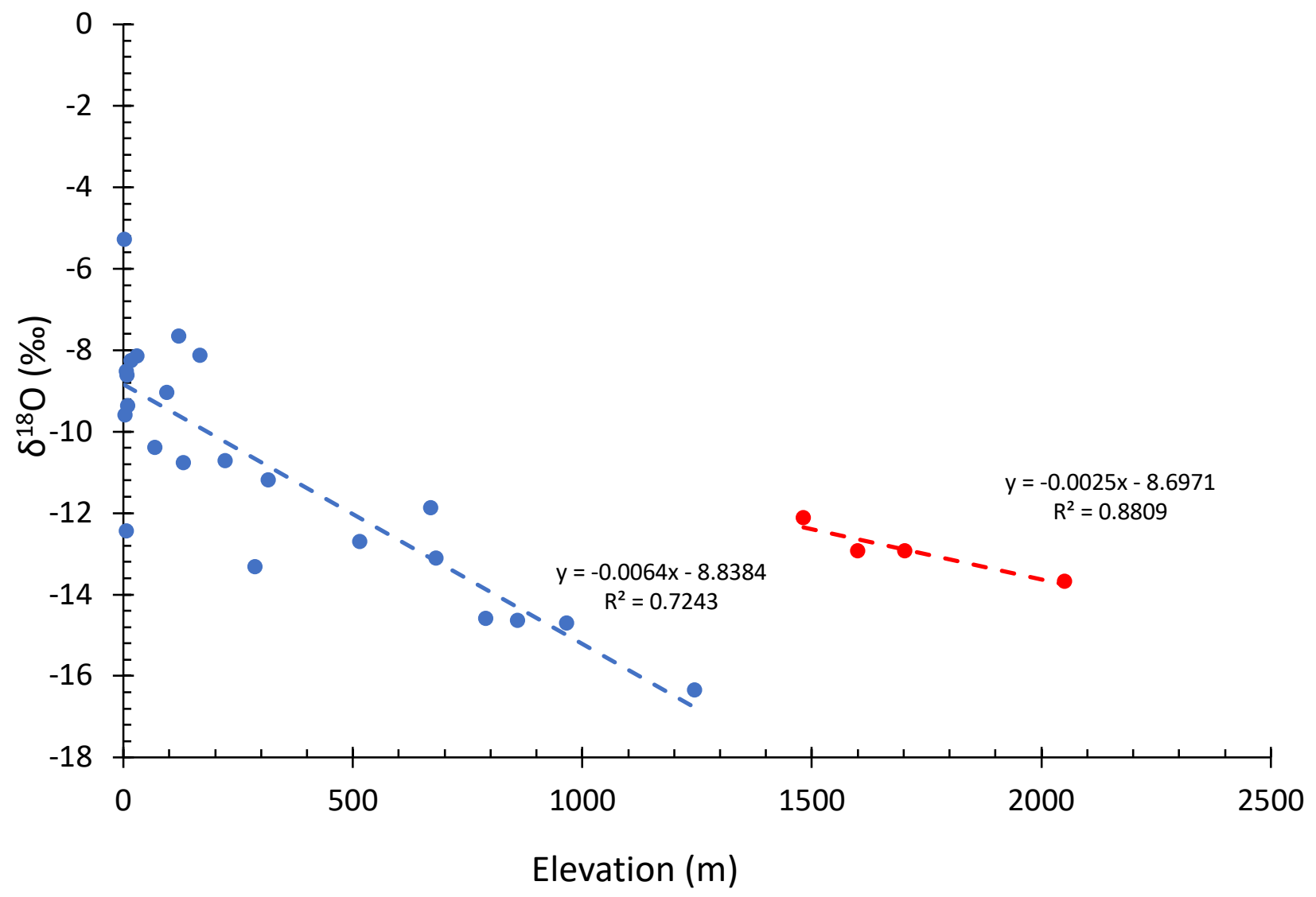

Figure 7. Plot of $\delta^{18} \mathrm{O}$ vs sample elevations for the windward side of the Cascades along $47 \pm 0.5^{\circ}$ latitude. Two trends are apparent; the red points and line are from samples collected at greater than 1300 meters (amsl) elevation, and blue points are from samples collected below 1300 meters elevation. 


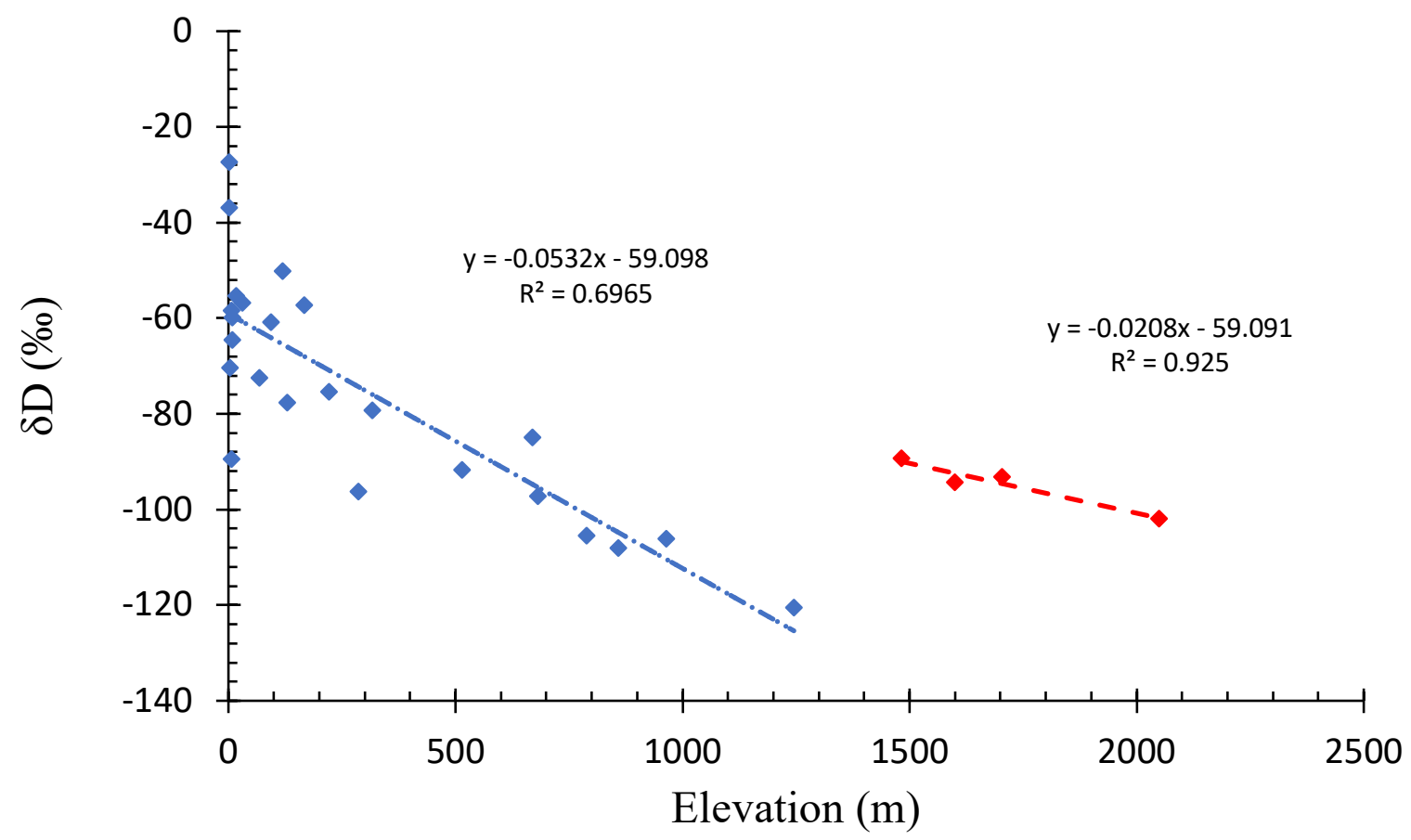

Figure 8. $\delta D$ vs sample elevations for the windward side of the Cascades along $47 \pm 0.5^{\circ}$ latitude. Red diamonds are from samples collected at elevations greater than 1300 meters (amsl), and blue diamonds are from samples collected below 1300 meters.

\subsubsection{Leeward Lapse Rate}

The LMWL for the leeward side of the High Cascades has a slope of 8.4 and a y-intercept of $+14.2 \%$. Both of these values are higher than the GMWL slope and y-intercept, 8 and $+10 \%$ respectively (Figure 9). The relatively high deuterium excess (y-intercept) suggests isotopic enrichment consistent with more arid regions (Gat \& Bowser, 1991) and, thus with the modern climate of the region, arid with little precipitation outside of winter

The leeward lapse rate is $12.9 \% / \mathrm{km}$ and shows a positive relationship between $\delta^{18} \mathrm{O}$ ratios and elevation (Figure 10). The $\mathrm{R}^{2}$-value for the linear relationship is 0.70 . Similarly, the plot of $\delta \mathrm{D}$ versus elevation presents a direct relationship between $\delta \mathrm{D}$ ratios in per mille and sample elevation with an $\mathrm{R}^{2}$ of 0.68 (Figure 11). The direct relationship that is present in these graphs is interpreted as ongoing Rayleigh Distillation but in a reverse manner than what is 
expected on the windward side of mountains and suggests the vapor mass is adiabatically heated as it travels to lower elevations (Rowley \& Garizone, 2007; Moran et al., 2007).

This type of relationship is rarely reported for the leeward side of mountain ranges. Often this relationship is not observed because of the turbulent mixing which occurs when an airmass moves over topographic barriers or due to the mixing of multiple air masses which can occur at convergent zones (Lapp et al., 2001; Moran et al., 2007; Smith, 1989). The dominant air masses for Washington state and the Pacific Northwest are maritime polar (mP) and continental polar (cP). These two air masses are expected to converge inland near the eastern boundary of western North America (Lapp et al., 2001; Moran et al., 2007). A convergence like this makes it unlikely to see the trend presented in Figures 10 and 11. Because it is present, it is expected that the dominate air mass is the $\mathrm{mP}$ because of the consistent trends for both the windward and leeward sides of the cascades. A cP air mass would be expected to be more negative in its isotopic composition than the values observed due to both colder temperatures and prolonged transport over the continent (Clark \& Fritz, 1999).

Five similar trends were reported in the Canadian Rocky Mountains for fresh snow fall. These lapse rates for $\delta^{18} \mathrm{O}$ range from $18 \% / \mathrm{km}$ (adjusted $\mathrm{R}^{2}=0.18$ ) to $3 \% \mathrm{o} / \mathrm{km}$ (adjusted $\mathrm{R}^{2}=0.08$ ) (Moran et al., 2007). It is expected that fit to a linear model is less ideal for these rates due to the varied direction of storm fronts which were both westerly and easterly (Moran et al., 2007). The trends observed over the Cascade Range also suggest that the $\mathrm{mP}$ air mass that travels over the High Cascades does not undergo turbulent mixing (Smith et al., 1989); turbulent mixing during transport would be an alternative reason as to why this type of relationship is not observed or poorly fits a linear trend (Moran et al., 2007). Additionally, the leeward lapse rates for both $\delta^{18} \mathrm{O}$ and $\delta \mathrm{D}$ support an unsplit path of transport for the air mass, as splitting of the air mass would promote mixing (Smith, 1989; Figure 10 \& Figure 11). 


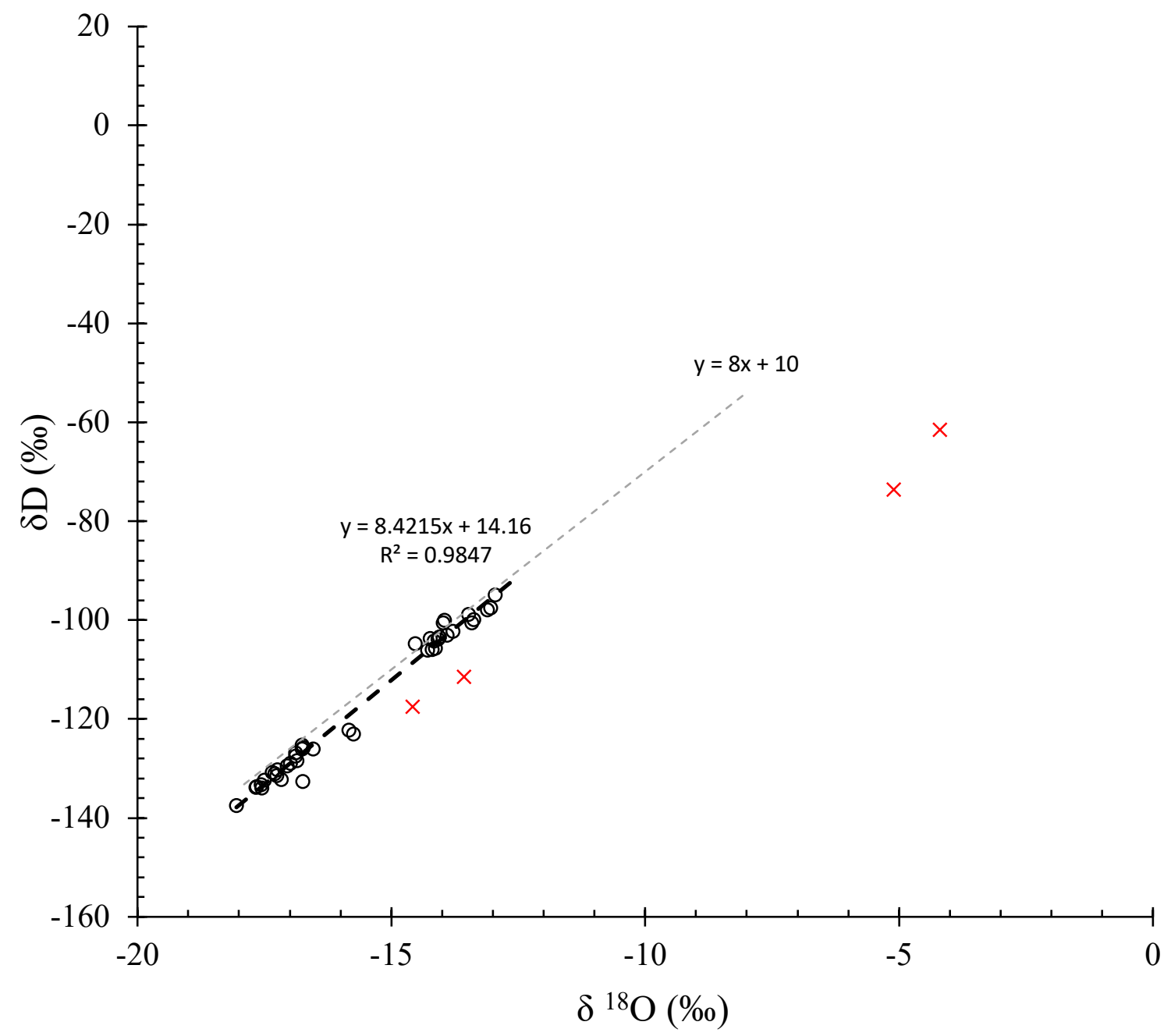

Figure 9. Graph of the leeward LMWL (black), with heavily evaporated samples (red) and the GMWL for reference as a gray dashed line. 


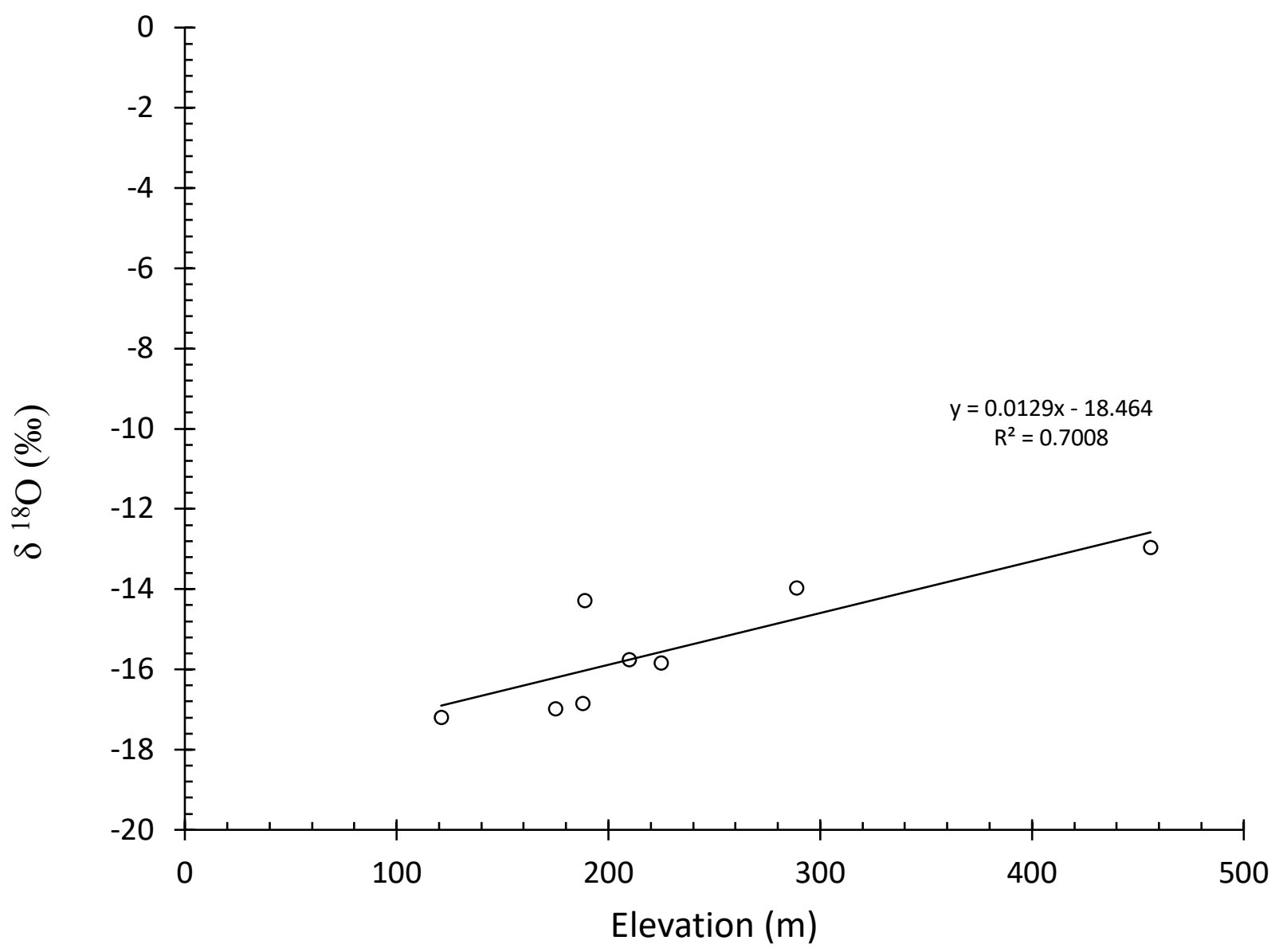

Figure 10. Graph of the leeward lapse rate for the Cascade Range along $47 \pm 0.5^{\circ}$ latitude. 


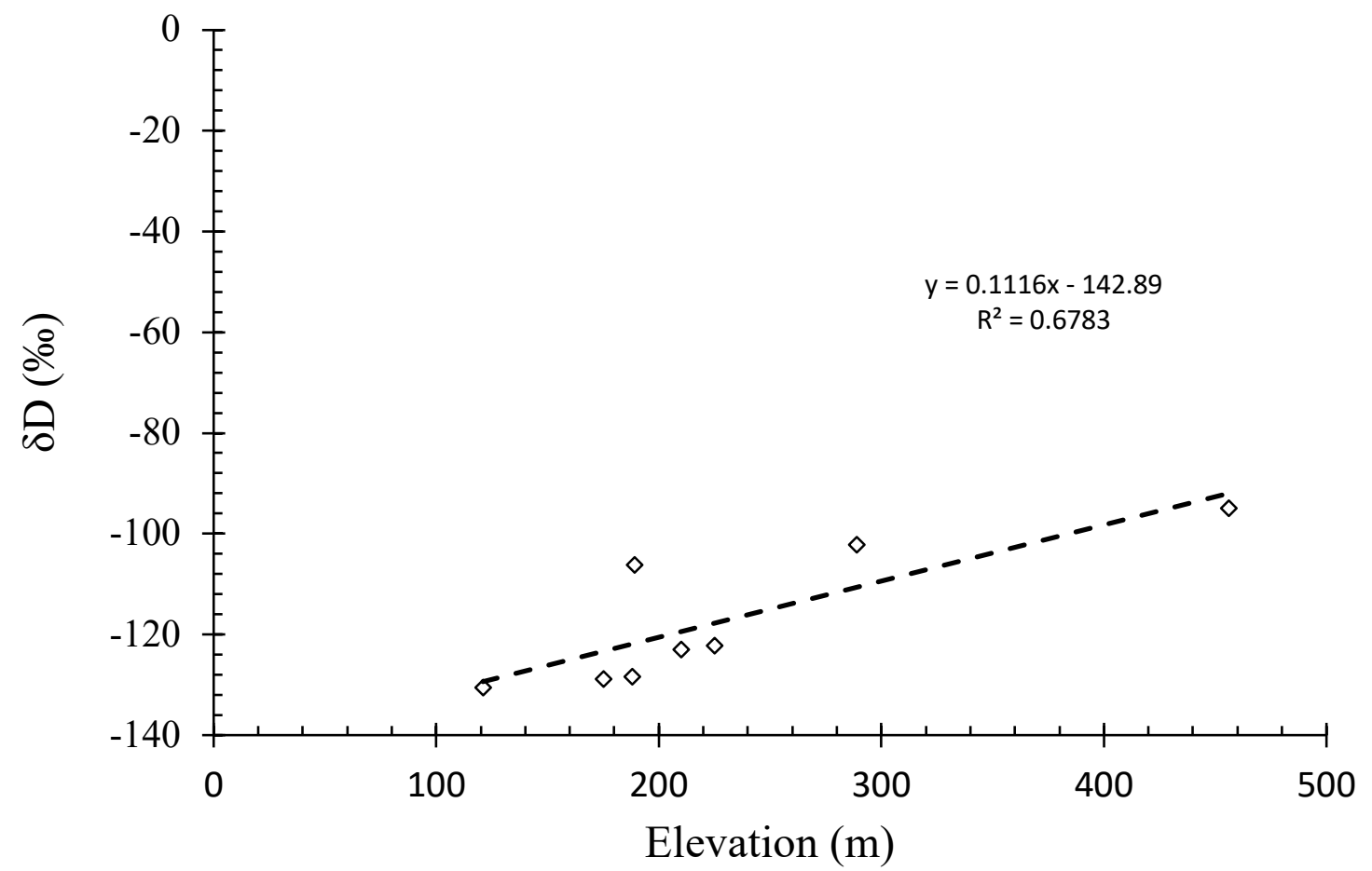

Figure 11. Plot of $\delta D$ vs sample elevations for the leeward side the High Cascades along $47 \pm 0.5^{\circ}$ latitude.

\subsection{Isotopic Composition Comparison Between Meteoric Waters and Groundwaters in Southeastern Washington}

The LMWL for the meteoric samples in the $46.0^{\circ}$ to $48.5^{\circ}$ latitude, and $-121.0^{\circ}$ to $-117.0^{\circ}$ bounding box is compared to the GMWL (Craig, 1961) along with the groundwater samples in Figure 12. The meteoric water samples show minimal evaporation when heavily evaporated points are removed with a slope of 8.1 with a y-intercept of $+9.4 \%$. Heavily evaporated meteoric water samples lie nicely along the groundwater trendline (Figure 12). The groundwater follows a linear trend well with an $\mathrm{R}^{2}$ of 0.92 . Groundwater samples appear to clump near the 150 D \%o value (Figure 12). 


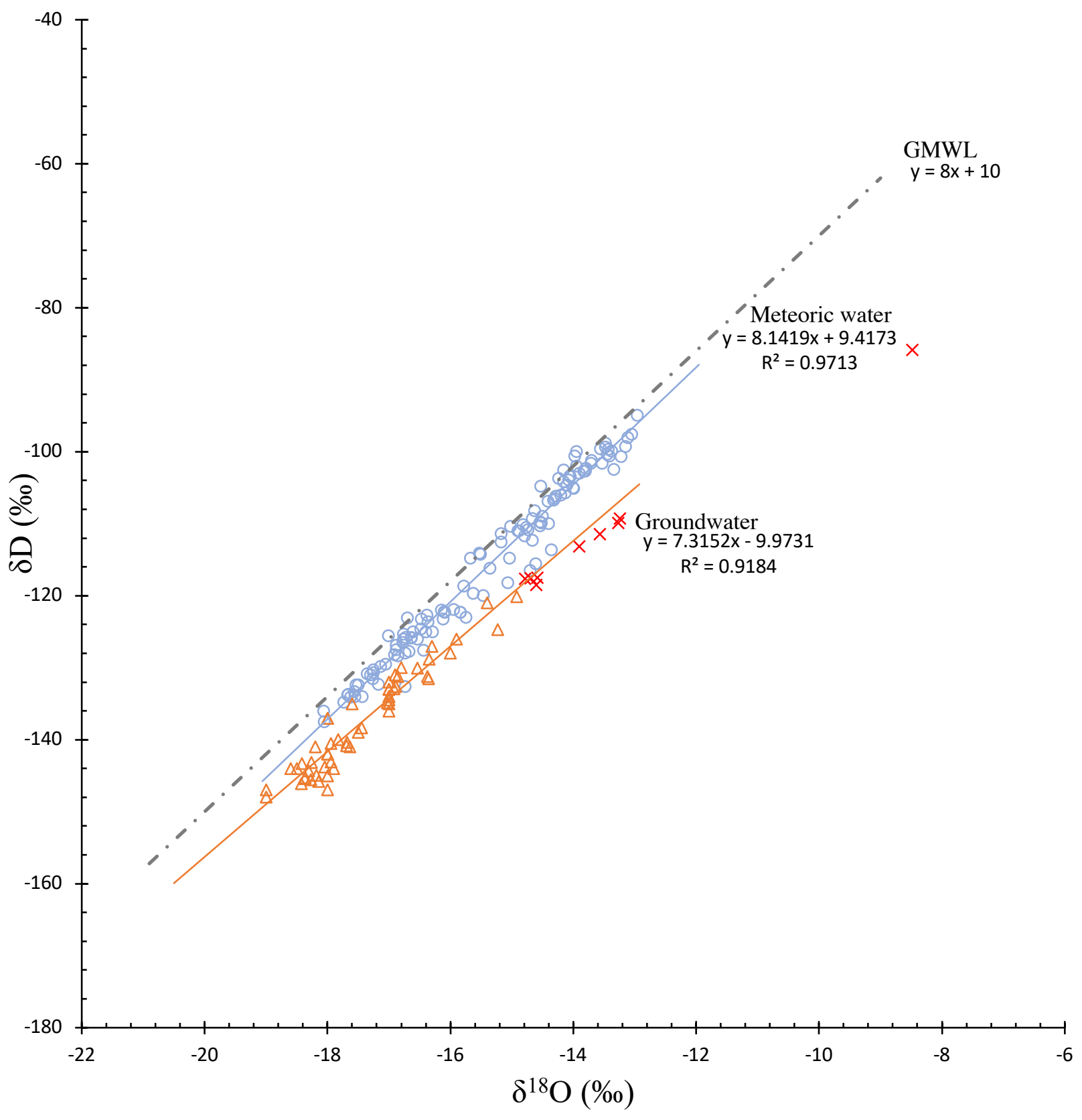

Figure 12. Graph of $\delta D$ vs $\delta^{18} O$ for the meteoric water (blue) and groundwater samples (orange). The meteoric water samples provide the LMWL for the region which is compared to the GMWL (gray dashed line) (Craig, 1960). Red Xs denote meteoric water samples that had d-indexes one standard deviation or more less than the average and were not included in the LMWL. 
The following box and whisker plots (Figure 13a \& Figure 13b) provide a visual representation of the differences between the meteoric waters and groundwaters. The meteoric water samples show more variability in both the deuterium and oxygen-eighteen ratios than is seen in the groundwater population. The Mann-Whitney $U$ tests indicate a significant difference between the two populations $(\mathrm{p}<0.0001$; alpha $=0.05)$ for both $\mathrm{D}$ and ${ }^{18} \mathrm{O}$. As expected, the groundwater samples are isotopically lighter than the meteoric water samples (Figures 13a \& $13 b)$.
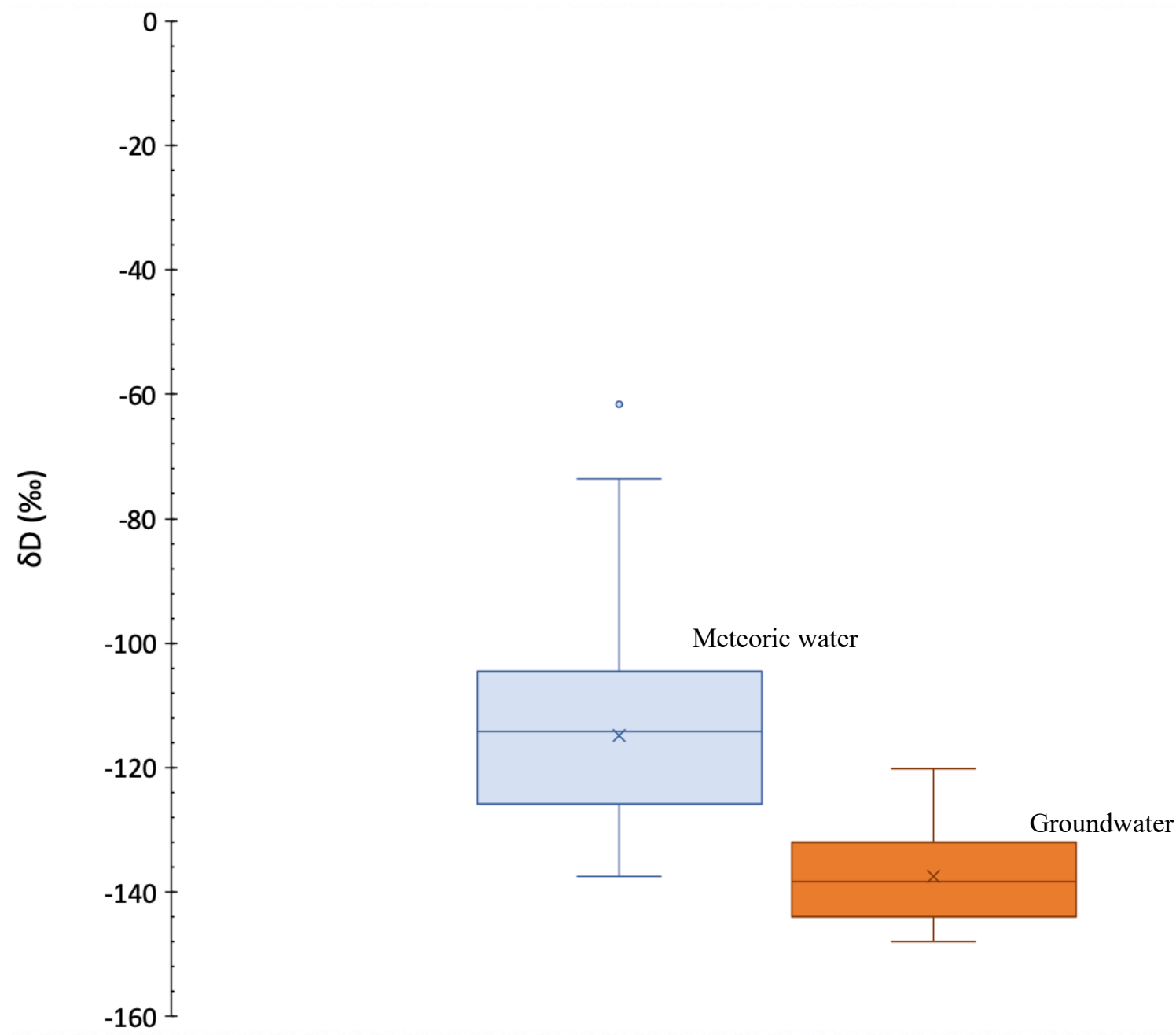

Figure 13a. Box and whisker plots comparing meteoric water and groundwater $\delta D$ samples. The light blue box is meteoric water $(n=130)$, and the orange box is groundwater $(n=55)$. 

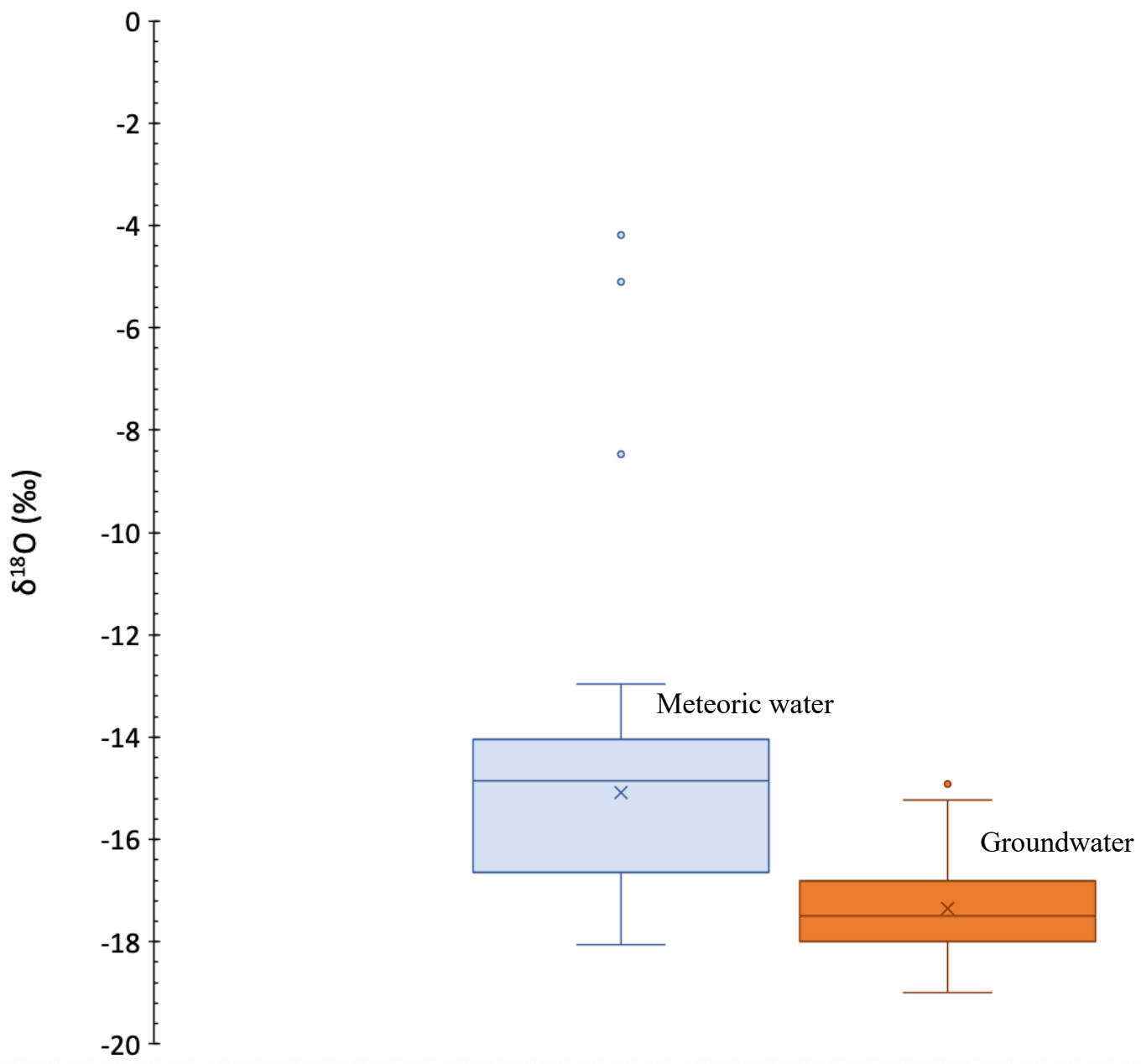

Figure 13b. Box and whisker plots comparing meteoric water and ground water $\delta^{18} \mathrm{O}$ samples. The light blue box is meteoric water $(n=131)$ and the orange box is groundwater $(n=72)$.

Figures $14 \mathrm{a}$ and $14 \mathrm{~b}$ plot isotopic ratios against time to determine any change seasonally in the isotopic composition. The meteoric water samples show seasonal variation in each of the five rivers plotted using their $\delta^{18} \mathrm{O}$ and $\delta \mathrm{D}$ values. The most predominant seasonal variations are in the Columbia River and the Yakima River (Figure 14a \& Figure 14b). These variation range in differences of isotopic values with season range from $10.2 \%$ - $1.9 \%$ for deuterium and 2.5 $\%_{0}-0.19 \%$ for oxygen-eighteen. The change in ${ }^{18} \mathrm{O}$ values is very limited and may simply be due to laboratory error as the range does not exceed $2.5 \%$. However, in Cle Elum, WA seasonal variation of oxygen-eighteen was reported to be $-17 \%$ in the winter and $-8 \%$ in the summer, a 
difference of $9 \%$, for precipitation and soil waters (Robertson \& Gazis, 2006). The continuous mixing of the rivers sampled are potentially dampening the signal of seasonal variation making this difference hard to distinguish without more consistent sampling over time. It has been suggested that the seasonality of precipitation is not recorded in shallow groundwaters, and this is expected with the samples evaluated for this study (Takeuchi et al., 2009), but because, the groundwater samples used in this study were not taken over a synchronous period of time, it may still be investigated.

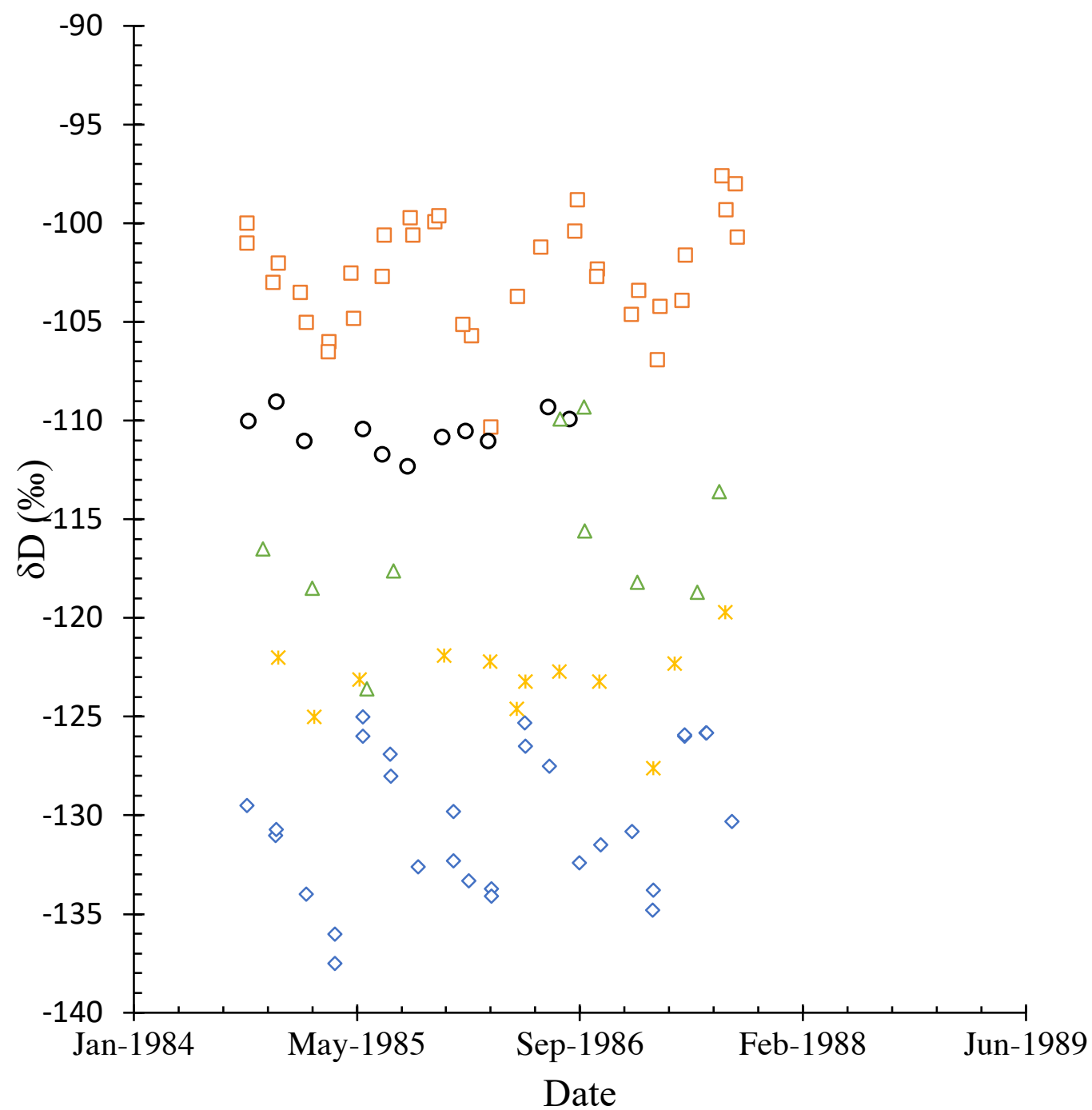

Figure 14a. A graph showing the $\delta D$ ratio against time for five rivers in SE WA. The blue diamonds represent the Columbia River, yellow Xs are the Snake River, green triangles are the Okanogan River, 
black circles are the Spokane River, and finally, orange squares show the Yakima River. The Columbia, Yakima, and Okanogo Rivers show a fairly consistent seasonal transition of decreasing isotopic composition through the fall and end of winter and then an increasing isotopic composition in late spring and summer.

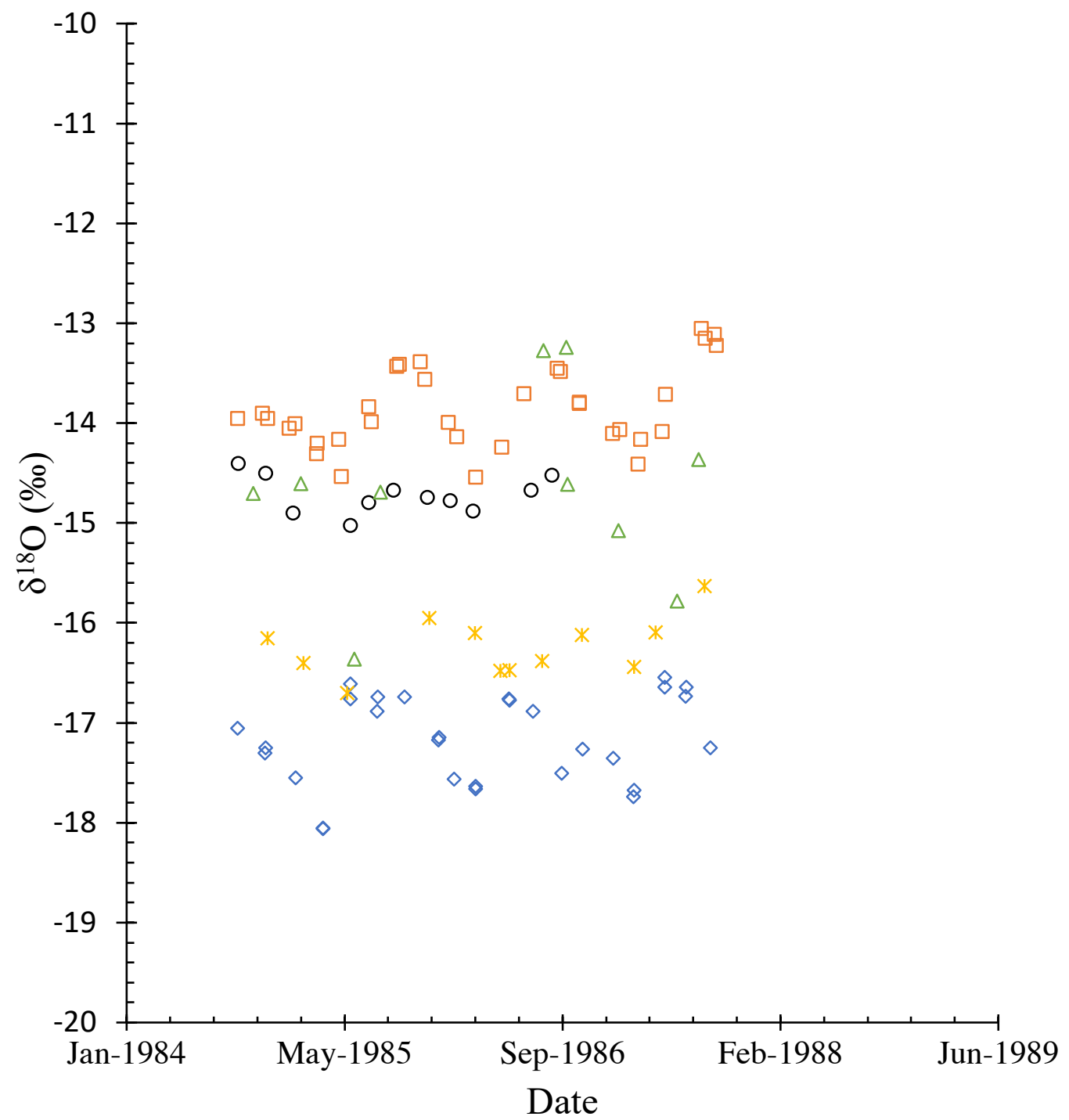

Figure 14b. Graph displaying the $\delta^{18} \mathrm{O}$ ratio against time for five rivers in SE WA in Figure 14a. A similar seasonal trend is present distinctly in two of the five rivers.

Figures $15 \mathrm{a}$ and $15 \mathrm{~b}$ plot the $\delta \mathrm{D}$ and $\delta^{18} \mathrm{O}$ of the groundwater samples against well bottom elevation. The completed linear regressions provided p-values of 0.0001 and $<0.0001$ $($ alpha $=0.05)$ for the plots of $\delta^{18} \mathrm{O}$ and $\delta \mathrm{D}$ respectively. There are two cutoffs in both graphs, showing the shallowest wells have the heaviest isotopic values with a cutoff at $500 \mathrm{~m}$ mean sea 
level (msl), and the deepest wells have the lightest isotopic values with a cutoff of $-150 \mathrm{~m}$ msl. For the values in-between these cutoffs, it is highly likely that groundwater mixing is occurring between aquifers at this range of well bottom elevations, thus, obscuring any clear trend between the two extremities. The shallow wells ( $>500 \mathrm{~m} \mathrm{msl})$ are most likely influenced by modern precipitation as their values range from $-130.0 \%$ to $-121.0 \%$ for deuterium and $-16.8 \%$ to $15.4 \%$ for oxygen-eighteen. These values fall within the range for several of the streams and rivers examined in this study (Figure 14a \& 14b). In contrast, the deeper wells $(<-150 \mathrm{~m} \mathrm{msl})$ have values of $-141.0 \%$ to $-145.4 \%$ and $-17.6 \%$ to $-18.5 \%$ (Figure $15 \mathrm{a} \& 15 \mathrm{~b}$ ) that are only achievable for $\delta^{18} \mathrm{O}$ from the Columbia River during the influx of winter precipitation (December to March) which has values of $-129.8 \%$ to $-137.5 \%$ for $\delta \mathrm{D}$ and $-17.17 \%$ to $18.05 \%$ for $\delta^{18} \mathrm{O}$ (Figure 14a \& 14b). The isotopic depletion seen in the deeper wells suggests that a colder climate was needed to achieve these values as current climate conditions do not.

Groundwaters from different wells have been age dated using $\mathrm{C}^{14}$ dating techniques and have a possible age range of thousands to tens of thousands of years (Douglas et al., 2009; Brown et al., 2011). Some of the deepest wells have been dated to a range of $15-33$ ka using ${ }^{14} \mathrm{C}$ (Brown et al., 2011); however, ${ }^{14} \mathrm{C}$ dating of groundwaters are insufficient for a final determination due to the possibility of rock water interactions of carbonates (Pearson \& Hanshaw, 1970; Plummer \& Glynn, 1992). The deeper groundwaters are consistent with Larson et al., 2000, and the most depleted in oxygen-eighteen further supporting that these waters were precipitated under a different climate regime and relatively old. The majority of these waters were mostly likely precipitated during the Last Glacial Maximum, during the late Pleistocene (Lecher et al., 2018; Takeuchi et al., 2009). It is suggested that there was a shift of source air mass roughly $5 \mathrm{ka}$ based on spring waters in the Olympic Peninsula. This shift is considered to be due to an increased ocean surface temperature and is closely related to the groundwater ages 
estimated (Slide \& Cvetic, 2011; Brown et al., 2011; Douglas et al., 2009). The proposed air mass shift is not a geographically unique climatic event as it can be correlated with other records and climate proxies that show a global warming pattern at similar time periods (Slide \& Cvetic, 2011; Huntley et al. 2002). As Slide and Cvetic (2011, p. 579) note, "A review of mid-Holocene warm periods from Greenland ice cores (e.g., Huntley et al. 2002), vegetation proxies in the Americas (e.g., Grimm et al. 2001), and limnology proxies in the Americas (e.g., Fritz et al. 2001) suggest one or two warming periods between 6,500- and 4,500-years BP. These temperature optima are observed more prominently in various climate proxies in Europe (e.g., Negendank, 2004).”

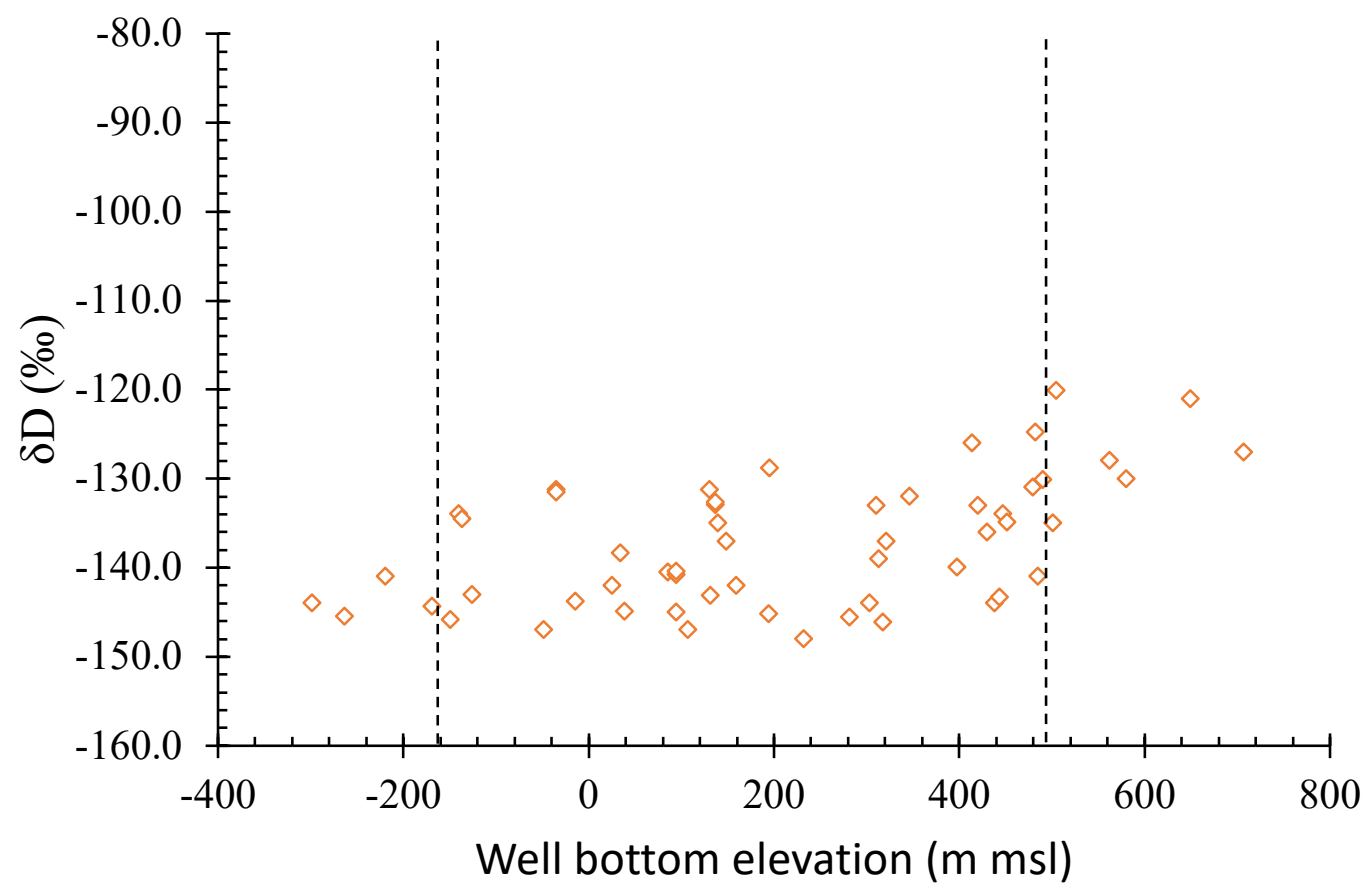

Figure 15a. Plot of $\delta D$ against well bottom elevation in meters to mean sea level. Black dashed lines represent proposed cutoffs at $-150 \mathrm{~m}$ and $500 \mathrm{~m}$. 


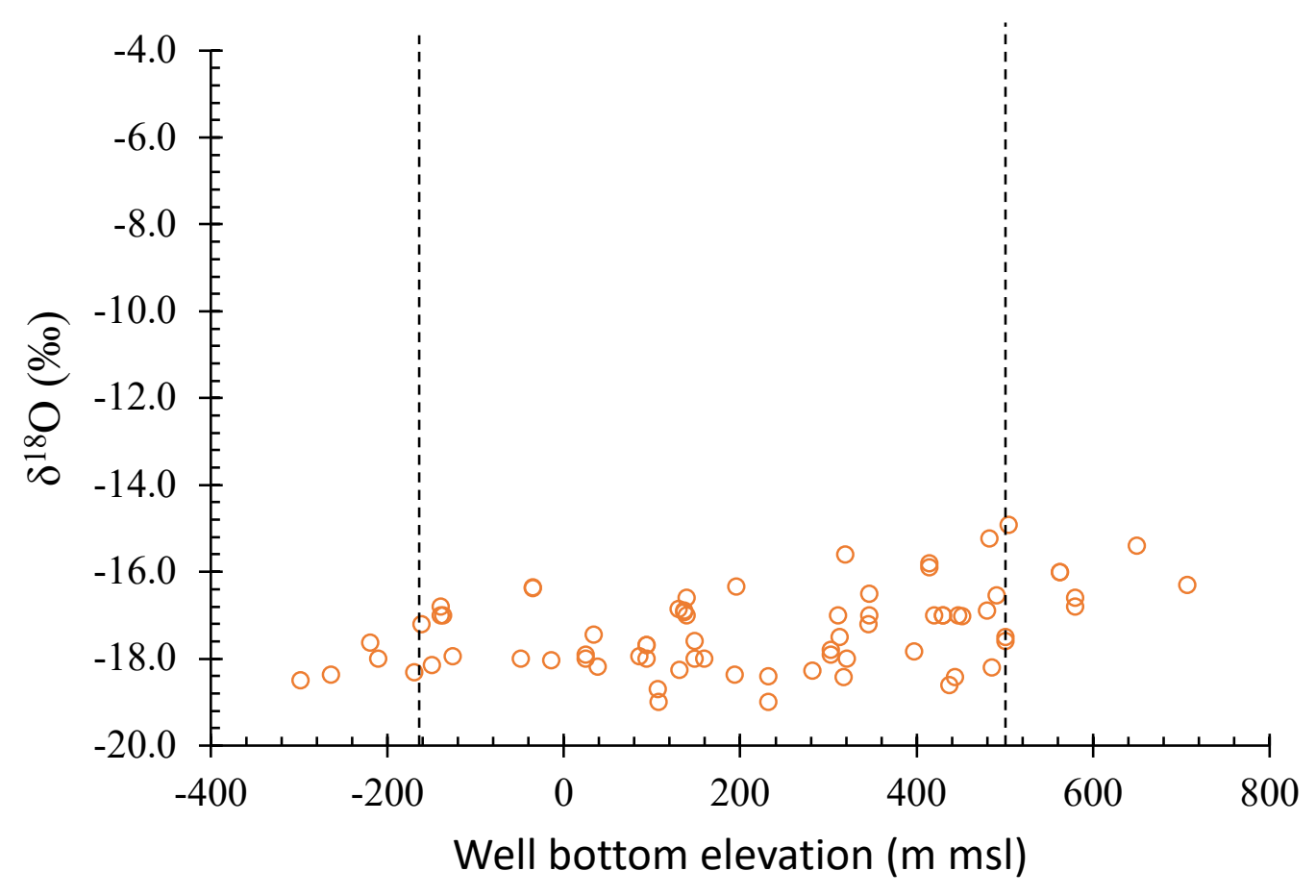

Figure 15b. Graph of $\delta 180$ against well bottom elevation in meters to mean sea level (msl). A slight increasing trend can be inferred. Black dashed lines represent proposed cutoffs at $-150 \mathrm{~m}$ and $500 \mathrm{~m}$.

\section{Conclusions}

The three isotopic lapse rates computed for this study help broaden our understanding of stable isotopes in the Pacific Northwest. The windward lapse rate for $\delta^{18} \mathrm{O}$ at low to mid elevations is $-6.4 \% / \mathrm{km}\left(\mathrm{R}^{2}=0.72\right)$ and is comparable to previously reported lapse rate of -5.1 $\%$ o $/ \mathrm{km}\left(\mathrm{R}^{2}=0.89\right)$ for the Olympic Peninsula (Sharp et al., 1960). The high-elevation windward lapse rate for $\delta^{18} \mathrm{O}$ of $-2.5 \% / \mathrm{km}\left(\mathrm{R}^{2}=0.88\right)$ compares very well with the combined Coast Range and High Cascades lapse rate of $-3.1 \% / \mathrm{km}\left(\mathrm{R}^{2}=0.70\right)$ (Bershaw et al., 2020) and the global average for mountain ranges, which is $-2.8 \%$ / $\mathrm{km}$ (Poage \& Chamberlin, 2001). The leeward lapse rate, $12.9 \% / \mathrm{km}\left(\mathrm{R}^{2}=0.72\right)$, provides new insight on the possibility that minimal atmospheric mixing occurs over the High Cascades and that the vapor cloud travels as an unsplit mass over the topography (Moran et al., 2007; Smith, 1989). 
The meteoric water and groundwater isotopic compositions are statistically significant in their differences to one another and the groundwater samples are isotopically lighter overall. Seasonal variation was seen in five of the rivers and winter precipitation values of these isotopes are closest in comparison to the shallowest wells $(>500 \mathrm{~m})$. Isotopic values from the deepest wells $(<-150 \mathrm{~m})$ are unique to themselves and not achievable with the current climatic conditions. The results of the study suggest that the groundwaters were precipitated during the Last Glacial Maximum and is supported by prior ${ }^{14} \mathrm{C}$ ages of $15-33 \mathrm{ka}$ for the oldest wells and on the scale of thousands of years for the youngest wells (Douglas et al., 2009; Brown et al., 2011). It is a possibility that the precipitation for the deepest wells concluded roughly $5 \mathrm{ka}$ when there was a proposed shift in the source air mass for the Olympic Peninsula from warming ocean surface temperature due to a global warming trend (Slide \& Cvetic, 2011; Huntley et al. 2002). This supports that the drawdowns currently being reported in eastern Washington are substantial because aquifer replenishment cannot keep pace with current pumping practices due to a change in climatic conditions.

Future research on this topic should investigate the possible seasonality of shallow groundwaters and further inquire about the potential of air mass confluence altering the isotopic compositions. Additionally, the potential of a wetter climate during the Last Glacial Maximum affecting recharge rates of aquifers should be examined. 


\section{References}

Bershaw, J., Hansen, D. D., Schauer, A. J. (2020), Deuterium Excess (d-excess) and 170 -excess $(\Delta 170)$ Variability in Meteoric Water across the Pacific Northwest, USA, Tellus B.

Brown, K. B., McIntosh, J. C., Rademacher, L. K., \& Lohse, K. A. (2011). Impacts of agricultural irrigation recharge on groundwater quality in a basalt aquifer system (Washington, USA): a multi-tracer approach. Hydrogeology Journal, 19(5), 1039-1051. https://doi.org/10.1007/s10040-011-0736-z

Clark, I. (2015). Groundwater geochemistry and isotopes. CRC press.

Clark, I. D., \& Fritz, P. (1999). Environmental isotopes in hydrogeology. CRC press.

Craig, H. (1961). Isotopic Variations in Meteoric Waters. Science, 133(3465), 1702-1703. https://doi.org/10.1126/science.133.3465.1702

Dansgaard, W. (1964). Stable isotopes in precipitation. Tellus, 16(4), 436-468. https://doi.org/10.1111/j.2153-3490.1964.tb00181.x

Douglas, A. A., Osiensky, J. L., \& Keller, C. K. (2007). Carbon-14 dating of ground water in the Palouse Basin of the Columbia River basalts. Journal of hydrology, 334(3-4), 502-512. https://doi.org/10.1016/j.jhydrol.2006.10.028

Dzurisin, D., Johnson, D. J., \& Symonds, R. B. (1983). Dry tilt network at Mount Rainier, Washington. US Geological Survey. https://pubs.usgs.gov/of/1983/0277/report.pdf

Garzione, C. N., Quade, J., DeCelles, P. G., \& English, N. B. (n.d.). Predicting paleoelevation of Tibet and the Himalaya from N18O vs. Altitude gradients in meteoric water across the Nepal Himalaya. Earth and Planetary Science Letters, 15.

Gat, J. R., \& Bowser, C. (1991). The heavy isotope enrichment of water in coupled evaporative systems. In Stable Isotope Geochemistry: A Tribute to Samuel Epstein (pp. 159-168).

Gat, J. R. (1996). Oxygen and hydrogen isotopes in the hydrologic cycle. Annual Review of Earth and Planetary Sciences, 24(1), 225-262.

Huntley, B., Baillie, M., Grove, J. M., Hammer, C. U., Harrison, S. P., Jacomet, S., Jansen, E., Karlén, W., Luterbacher, N., Negendank, J., and Schibler, J. (2002). Holocene palaeoenvironmental changes in north-west Europe: Climatic implications and the human dimension. In Climate development and history of the North Atlantic realm (pp. 259-298). Springer, Berlin, Heidelberg.

IAEA (2020). Global Network of Isotopes in Rivers. The GNIR Database. Accessible at: https://nucleus.iaea.org/wiser

Lapp, S., Byrne, J., Kienzle, S., \& Townshend, I. (2002). Linking global circulation model 
synoptics and precipitation for western North America. International Journal of Climatology: A Journal of the Royal Meteorological Society, 22(15), 1807-1817.

Larson, K. R. (2000). Stable isotopes in the Pullman-Moscow Basin, Eastern Washington and North Idaho: Implications for the timing, magnitude and distribution of groundwater recharge (Doctoral dissertation, Washington State University).

Lechler, A. R., \& Niemi, N. A. (2012). The influence of snow sublimation on the isotopic composition of spring and surface waters in the southwestern United States: Implications for stable isotope-based paleoaltimetry and hydrologic studies. Geological Society of America Bulletin, 124(3-4), 318-334. https://doi.org/10.1130/B30467.1

Lechler, Alex R., Huntington, K. W., Breecker, D. O., Sweeney, M. R., \& Schauer, A. J. (2018). Loess-paleosol carbonate clumped isotope record of late Pleistocene-Holocene climate change in the Palouse region, Washington State, USA. Quaternary Research, 90(2), 331347. https://doi.org/10.1017/qua.2018.47

Papadopoulos, S. S. \& Associates. (2012) Columbia Basin Ground Water Management Area Municipal Groundwater Supply Review: Current Conditions and Predicted Future Conditions: Columbia Basin groundwater management area of Adams, Franklin, Grant, and Lincoln Counties, Othello, Washington.

Pearson, F. J., \& Hanshaw, B. B. (1970). Sources of dissolved carbonate species in groundwater and their effects on carbon-14 dating. Isotope hydrology, 1970, 271-285.

Plummer, L. N., \& Glynn, P. D. (1992). Radiocarbon dating in groundwater systems. MooN, 100, 4-1.

Poage, M. A., \& Chamberlin, P. C., (2001). Empirical relationships between elevation and the stable isotope composition of precipitation and surface waters: Considerations for studies of paleoelevation change. American Journal of Science, 301(1), 1-15. https://doi.org/10.2475/ajs.301.1.1

Reidel, S. P., \& Tolan, T. L. (2013). The Grande Ronde Basalt, Columbia River Basalt Group. In S. P. Reidel, V. E. Camp, M. E. Ross, J. A. Wolff, B. S. Martin, T. L. Tolan, \& R. E. Wells, The Columbia River Flood Basalt Province. Geological Society of America. https://doi.org/10.1130/2013.2497(05)

Robertson, J. A., \& Gazis, C. A. (2006). An oxygen isotope study of seasonal trends in soil water fluxes at two sites along a climate gradient in Washington state (USA). Journal of Hydrology, 328(1-2), 375-387. https://doi.org/10.1016/j.jhydrol.2005.12.031

Rowley, D. B., \& Garzione, C. N. (2007). Stable Isotope-Based Paleoaltimetry. Annual Review of Earth and Planetary Sciences, 35(1), 463-508. https://doi.org/10.1146/annurev.earth.35.031306.140155 
Sidle, W. C., \& Cvetic, V. (2011). Stable water isotope climate archives in springs from the Olympic Mountains, Washington. Environmental Earth Sciences, 62(3), 569-580.

https://doi.org/10.1007/s12665-010-0548-9

Smith, G. I., Friedman, I., Klieforth, H., \& Hardcastle, K. (1979). Areal distribution of deuterium in eastern California precipitation, 1968-1969. Journal of Applied Meteorology, 18(2), 172-188.

Smith, R. B. (1989). Hydrostatic airflow over mountains. In Advances in geophysics (Vol. 31, pp. 1-41). Elsevier. https://doi.org/10.1016/S0065-2687(08)60052-7

Takeuchi, A., Goodwin, A. J., Moravec, B. G., Larson, P. B., \& Keller, C. K. (2009). Isotopic evidence for temporal variation in proportion of seasonal precipitation since the last glacial time in the inland Pacific Northwest of the USA. Quaternary Research, 72(2), 198-206. https://doi.org/10.1016/j.yqres.2009.06.001

Tolan, T. L., Martin, B. S., Reidel, S. P., Anderson, J. L., Lindsey, K. A., \& Burt, W. (2009). An introduction to the stratigraphy, structural geology, and hydrogeology of the Columbia River Flood-Basalt Province: A primer for the GSA Columbia River Basalt Group field trips. Geol. Soc. Am. Field Guide, 15, 599-643

Tolan, T. L., Lindsey, K., Porcello, J. (2009) A summary of Columbia River Basalt Group and its influence on the hydrogeology of the Columbia River Basalt aquifer system. The Columbia Basin Ground Water Management Area of the Adams, Franklin, Grant, and Lincoln counties. Othello, Washington.

Vaccaro, J. J. (1999). Summary of the Columbia Plateau, Regional Aquifer-system Analysis, Washington, Oregon, and Idaho (Vol. 1413). US Geological Survey.

Vlassopoulos, D., Goin, J., Zeliff, M., Porcello, J., Tolan, T., \& Lindsey, K. (2009). Groundwater geochemistry of the Columbia River basalt group aquifer system: Columbia Basin groundwater management area of Adams, Franklin, Grant, and Lincoln Counties. Columbia River basalt group aquifer system. The Columbia Basin groundwater management area of Adams, Franklin, Grant, and Lincoln Counties, Othello, Washington.

WaterIsotopes Database. (2020). http://waterisotopesDB.org. Accessed 05/04/2020. Query: Country $=$ USA, State $=$ WA, Type $=$ River or Stream \& Type $=$ Lake.

Urey, H. C. (1947). The thermodynamic properties of isotopic substances. Journal of the Chemical Society (Resumed), 562-581. https://doi.org/10.1039/JR9470000562 
Appendix A. Groundwater data used for isotopic comparison (Vlassopoulos et al., 2009).

\begin{tabular}{|c|c|c|c|c|c|c|c|c|c|}
\hline Site Number & Sample & $\begin{array}{l}\text { Collection } \\
\text { Date }\end{array}$ & Longitude & Latitude & $\begin{array}{c}\text { Ground } \\
\text { surface } \\
\text { elevation (m } \\
\text { msl) }\end{array}$ & $\begin{array}{c}\text { Well } \\
\text { bottom } \\
\text { depth (m } \\
\text { msl) }\end{array}$ & $\begin{array}{c}\text { Well } \\
\text { bottom } \\
\text { elevation } \\
\text { (m msl) }\end{array}$ & $\begin{array}{c}\text { бD (per } \\
\text { mille) }\end{array}$ & $\begin{array}{c}\delta^{18} \mathrm{O} \text { (per } \\
\text { mille) }\end{array}$ \\
\hline 464928119103201 & BA050 & $3 / 15 / 83$ & -119.1761246 & 46.82430750 & 320 & 369 & -49 & -147.0 & -18.0 \\
\hline 465206118524401 & BA073 & $5 / 24 / 83$ & -118.8880572 & 46.87347516 & 434 & 409 & 25 & -142.0 & -18.0 \\
\hline 465206118524401 & BA074 & 9/9/82 & -118.8880572 & 46.87347516 & 434 & 409 & 25 & & -17.9 \\
\hline 465253118420202 & BA081 & $3 / 17 / 83$ & -118.7030488 & 46.88069820 & 504 & 183 & 321 & -137.0 & -18.0 \\
\hline 465342118145402 & BA090 & $5 / 25 / 83$ & -118.2471884 & 46.89348360 & 475 & 61 & 414 & -126.0 & -15.9 \\
\hline 465342118145402 & BA092 & $8 / 5 / 82$ & -118.2471884 & 46.89348360 & 475 & 61 & 414 & & -15.8 \\
\hline 465347118531301 & BA093 & $3 / 15 / 83$ & -118.9344480 & 46.82347460 & 396 & 165 & 232 & -148.0 & -19.0 \\
\hline 465347118531301 & BA095 & 9/8/82 & -118.9344480 & 46.82347460 & 396 & 165 & 232 & & -18.4 \\
\hline 465840118584601 & BA115 & $3 / 17 / 83$ & -118.9811167 & 46.97764280 & 385 & 38 & 346 & -132.0 & -17.0 \\
\hline 465840118584601 & BA117 & $8 / 11 / 82$ & -118.9811167 & 46.97764280 & 385 & 38 & 346 & & -16.5 \\
\hline 465853118365101 & BA123 & $3 / 17 / 83$ & -118.6152652 & 46.98125599 & 470 & 311 & 159 & -142.0 & -18.0 \\
\hline 465900118522701 & BA128 & $8 / 10 / 82$ & -118.8750010 & 46.98319838 & 384 & 595 & -210 & & -18.0 \\
\hline 470048118561701 & BA137 & $5 / 19 / 83$ & -118.9388927 & 47.01264310 & 433 & 732 & -298 & -144.0 & -18.5 \\
\hline 471315118282201 & BA231 & $5 / 24 / 83$ & -118.4727600 & 47.22042619 & 588 & 104 & 485 & -141.0 & -18.2 \\
\hline 471347118471701 & BA239 & $3 / 18 / 83$ & -118.7894426 & 47.22986750 & 487 & 67 & 420 & -133.0 & -17.0 \\
\hline GB06180802 & BA252 & $6 / 18 / 08$ & -118.7379000 & 46.76611700 & 405 & 669 & -264 & -145.4 & -18.4 \\
\hline GB06190801 & BA253 & $6 / 19 / 08$ & -118.7786670 & 47.13050000 & 506 & 313 & 194 & -145.2 & -18.4 \\
\hline GB06190804 & BA254 & $6 / 19 / 08$ & -118.9537330 & 47.26083300 & 502 & 185 & 317 & -146.1 & -18.4 \\
\hline GB06250801 & BA255 & $6 / 25 / 08$ & -118.7506500 & 47.10103300 & 501 & 670 & -169 & -144.4 & -18.3 \\
\hline GB07080805 & BA256 & $7 / 8 / 08$ & -118.264767 & 47.25665 & 545 & 40 & 504 & -120.1 & -14.9 \\
\hline 463340119043901 & BF034 & $3 / 10 / 83$ & -119.0755648 & 46.5612494 & 279 & 139 & 139 & -135.0 & -17.0 \\
\hline 463340119043901 & BF037 & $9 / 1 / 82$ & -119.0755648 & 46.56124940 & 279 & 139 & 139 & & -16.6 \\
\hline
\end{tabular}




\begin{tabular}{|c|c|c|c|c|c|c|c|c|c|}
\hline 463857118474101 & BF053 & $5 / 18 / 83$ & -118.7849974 & 46.64597330 & 240 & 91 & 148 & -137.0 & -18.0 \\
\hline 463857118474101 & BF055 & $8 / 31 / 82$ & -118.7849974 & 46.64597330 & 240 & 91 & 148 & & -17.6 \\
\hline 465152118383801 & BF108 & $3 / 10 / 83$ & -118.8744456 & 46.64291748 & 262 & 402 & -140 & -134.0 & -17.0 \\
\hline 465152118383801 & BF110 & $8 / 31 / 82$ & -118.8744456 & 46.64291748 & 262 & 402 & -140 & & -16.8 \\
\hline GB06180801 & BF111 & $6 / 18 / 08$ & -118.8467500 & 46.71386700 & 336 & 250 & 86 & -140.5 & -17.9 \\
\hline GB06230803 & BF113 & $6 / 23 / 08$ & -118.856817 & 46.706833 & 339 & 245 & 94 & -140.8 & -17.7 \\
\hline GB07080801 & BF114 & $7 / 8 / 08$ & -118.8529500 & 46.66303300 & 270 & 305 & -35 & -131.2 & -16.4 \\
\hline GB07080803 & BF115 & $7 / 8 / 08$ & -118.8747830 & 46.64348300 & 267 & 404 & -137 & -134.5 & -17.0 \\
\hline GB06230803 & BF116 & $6 / 23 / 08$ & -118.856817 & 46.706833 & 339 & 245 & 94 & -140.4 & -17.7 \\
\hline GB07080802 & BF117 & $7 / 8 / 08$ & -118.8529500 & 46.66303300 & 270 & 305 & -35 & -131.6 & -16.4 \\
\hline 465717119535802 & BG119 & $8 / 19 / 82$ & -119.9000491 & 46.95679958 & 382 & 276 & 106 & & -18.7 \\
\hline 465948119542001 & BG134 & $8 / 19 / 82$ & -119.9047722 & 46.99902187 & 456 & 111 & 345 & & -17.2 \\
\hline 470140119161901 & BG157 & $5 / 17 / 83$ & -119.2730756 & 47.02208626 & 338 & 244 & 94 & -145.0 & -18.0 \\
\hline 470236119024101 & BG163 & $3 / 18 / 83$ & -119.0461202 & 47.04264310 & 367 & 56 & 310 & -133.0 & -17.0 \\
\hline 471725119214501 & BG352 & $7 / 26 / 82$ & -119.3525275 & 47.30458568 & 354 & 35 & 319 & & -15.6 \\
\hline 471812119000002 & BG354 & $5 / 18 / 83$ & -119.0008424 & 47.29570060 & 513 & 405 & 107 & -147.0 & -19.0 \\
\hline 471920119320501 & BG363 & $7 / 27 / 82$ & -119.5369817 & 47.31847210 & 403 & 564 & -161 & & -17.2 \\
\hline GB06190803 & BG498 & $6 / 19 / 08$ & -119.0011670 & 47.30481700 & 484 & 633 & -149 & -145.8 & -18.1 \\
\hline GB06240805 & BG499 & $6 / 24 / 08$ & -119.1932000 & 47.13070000 & 374 & 178 & 195 & -128.8 & -16.3 \\
\hline GB06240806 & BG500 & $6 / 24 / 08$ & -119.1930830 & 47.12415000 & 367 & 381 & -14 & -143.8 & -18.0 \\
\hline GB07070803 & BG502 & $7 / 7 / 08$ & -119.6287000 & 46.89958300 & 315 & 277 & 38 & -144.9 & -18.2 \\
\hline GB07070804 & BG503 & $7 / 7 / 08$ & -119.6296500 & 46.91035000 & 345 & 311 & 34 & -138.3 & -17.4 \\
\hline GB07150801 & BG504 & $7 / 15 / 08$ & -119.0368500 & 46.96990000 & 390 & 253 & 137 & -133.0 & -16.9 \\
\hline GB07150803 & BG505 & $7 / 15 / 08$ & -119.0269170 & 46.96576700 & 391 & 261 & 130 & -131.3 & -16.9 \\
\hline GB07150802 & BG507 & $7 / 15 / 08$ & -119.0368500 & 46.96990000 & 390 & 253 & 137 & -132.6 & -16.9 \\
\hline 471741117590201 & BL025 & $6 / 20 / 83$ & -117.9821736 & 47.29682490 & 583 & 153 & 430 & -136.0 & -17.0 \\
\hline 471741117590201 & BL026 & $7 / 21 / 82$ & -117.9821736 & 47.29682490 & 583 & 153 & 430 & & -17.0 \\
\hline 471835117583101 & BL032 & $6 / 2 / 83$ & -117.9755068 & 47.30960278 & 616 & 54 & 562 & -128.0 & -16.0 \\
\hline 471835117583101 & BL033 & $7 / 21 / 82$ & -117.9755068 & 47.30960278 & 616 & 54 & 562 & & -16.0 \\
\hline 472307118224002 & BL073 & $6 / 1 / 83$ & -118.3785902 & 47.38542915 & 585 & 105 & 479 & -131.0 & -16.9 \\
\hline
\end{tabular}




\begin{tabular}{|c|c|c|c|c|c|c|c|c|c|}
\hline 472638118560101 & BL095 & $6 / 2 / 83$ & -118.9347295 & 47.44375750 & 522 & 209 & 313 & -139.0 & -17.5 \\
\hline 473443118531501 & BL144 & $6 / 3 / 83$ & -118.8897294 & 47.57514777 & 577 & 76 & 501 & -135.0 & -17.6 \\
\hline 473443118531501 & BL145 & $7 / 23 / 82$ & -118.8897294 & 47.57514777 & 577 & 76 & 501 & & -17.5 \\
\hline 473648118452301 & BL153 & $6 / 4 / 83$ & -118.7563904 & 47.61320437 & 650 & 348 & 303 & -144.0 & -17.9 \\
\hline 473648118452301 & BL155 & $9 / 9 / 82$ & -118.7563904 & 47.61320437 & 650 & 348 & 303 & & -17.8 \\
\hline 473829118381901 & BL158 & $6 / 3 / 83$ & -118.6397194 & 47.64126187 & 706 & 259 & 447 & -134.0 & -17.0 \\
\hline 473832118081801 & BL159 & $5 / 31 / 83$ & -118.1394164 & 47.63848995 & 737 & 30 & 707 & -127.0 & -16.3 \\
\hline 473848118091901 & BL162 & $6 / 1 / 83$ & -118.156362 & 47.64654545 & 735 & 297 & 437 & -144.0 & -18.6 \\
\hline 474142118235502 & BL172 & $6 / 2 / 83$ & -118.3997097 & 47.69487690 & 710 & 61 & 649 & -121.0 & -15.4 \\
\hline 474337118454201 & BL179 & $6 / 4 / 83$ & -118.7627826 & 47.72653927 & 630 & 51 & 580 & -130.0 & -16.8 \\
\hline 474337118454201 & BL180 & $7 / 23 / 82$ & -118.7627826 & 47.72653927 & 630 & 51 & 580 & & -16.6 \\
\hline GB06230802 & BL223 & $6 / 23 / 08$ & -118.7769000 & 47.29191700 & 559 & 684 & -126 & -143.1 & -17.9 \\
\hline GB06240802 & BL224 & $6 / 24 / 08$ & -118.8624000 & 47.26853300 & 539 & 258 & 281 & -145.6 & -18.3 \\
\hline GB06240803 & BL225 & $6 / 24 / 08$ & -118.899233 & 47.275483 & 543 & 91 & 452 & -134.9 & -17.0 \\
\hline GB06240810 & BL226 & $6 / 24 / 08$ & -118.6247500 & 47.55171700 & 635 & 504 & 131 & -143.2 & -18.3 \\
\hline GB06240811 & BL227 & $6 / 24 / 08$ & -118.6574 & 47.51635 & 627 & 137 & 490 & -130.1 & -16.5 \\
\hline GB06250802 & BL228 & $6 / 25 / 08$ & -118.8467170 & 47.30173300 & 521 & 741 & -220 & -141.0 & -17.6 \\
\hline GB06250803 & BL229 & $6 / 25 / 08$ & -118.8523500 & 47.28251700 & 543 & 61 & 482 & -124.7 & -15.2 \\
\hline GB07080804 & BL230 & $7 / 8 / 08$ & -118.2676330 & 47.27580000 & 582 & 184 & 397 & -140.0 & -17.8 \\
\hline GB07140801 & BL231 & $7 / 14 / 08$ & -118.1562170 & 47.64786700 & 740 & 297 & 443 & -143.3 & -18.4 \\
\hline
\end{tabular}

Appendix B. Meteoric water used for comparison (WaterIsotopes, 2020; IAEA, 2020).

\begin{tabular}{|c|c|c|c|c|c|c|c|c|c|c|c|}
\hline Sample ID & Site Name & $\begin{array}{l}\text { Collection } \\
\text { Date }\end{array}$ & Latitude & Longitude & $\begin{array}{c}\text { Collection } \\
\text { Elevation } \\
\text { (mabsl) }\end{array}$ & Type & $\begin{array}{c}\text { סD (per } \\
\text { mille) }\end{array}$ & $\begin{array}{c}\delta^{18} O \text { (per } \\
\text { mille) }\end{array}$ & d & $\begin{array}{l}\text { WI Analysis } \\
\text { Source }\end{array}$ & $\begin{array}{l}\text { Project } \\
\text { ID }\end{array}$ \\
\hline $\begin{array}{c}\text { NRSA0809- } \\
1894\end{array}$ & $\begin{array}{c}\text { Ahtanum } \\
\text { Creek }\end{array}$ & $\begin{array}{c}7 / 27 / 09 \\
0: 00\end{array}$ & 46.5270582 & $\begin{array}{c}- \\
120 . \overline{78425}\end{array}$ & & River_or_stream & -114.26 & -15.51 & 9.80 & EPA & 165 \\
\hline CK_ 4224 & $\begin{array}{c}\text { Columbia R } \\
\text { At Vernita Br } \\
\text { Nr Priest } \\
\text { Rpds Dm }\end{array}$ & $\begin{array}{c}9 / 30 / 85 \\
0: 00\end{array}$ & 46.63999 & -119.7317 & & River_or_stream & -132.60 & -16.74 & 1.32 & USGS & 48 \\
\hline
\end{tabular}




\begin{tabular}{|c|c|c|c|c|c|c|c|c|c|c|}
\hline CK_4225 & $\begin{array}{c}\text { Columbia R } \\
\text { At Vernita Br } \\
\text { Nr Priest } \\
\text { Rpds Dm }\end{array}$ & $\begin{array}{c}12 / 17 / 85 \\
0: 00\end{array}$ & 46.63999 & -119.7317 & River_or_stream & -132.30 & -17.17 & 5.06 & USGS & 48 \\
\hline CK_4234 & $\begin{array}{c}\text { Columbia R } \\
\text { At Vernita Br } \\
\text { Nr Priest } \\
\text { Rpds Dm }\end{array}$ & $\begin{array}{c}5 / 19 / 87 \\
0: 00 \\
\end{array}$ & 46.63999 & -119.7317 & River_or_stream & -126.00 & -16.54 & 6.32 & USGS & 48 \\
\hline CK_4220 & $\begin{array}{c}\text { Columbia R } \\
\text { At Vernita Br } \\
\text { Nr Priest } \\
\text { Rpds Dm } \\
\end{array}$ & $\begin{array}{c}1 / 22 / 85 \\
0: 00 \\
\end{array}$ & 46.63999 & -119.7317 & River_or_stream & -134.00 & -17.55 & 6.40 & USGS & 48 \\
\hline CK_4231 & $\begin{array}{c}\text { Columbia R } \\
\text { At Vernita Br } \\
\text { Nr Priest } \\
\text { Rpds Dm }\end{array}$ & $\begin{array}{c}11 / 12 / 86 \\
0: 00\end{array}$ & 46.63999 & -119.7317 & River_or_stream & -131.50 & -17.26 & 6.58 & USGS & 48 \\
\hline CK_4218 & $\begin{array}{c}\text { Columbia R } \\
\text { At Vernita Br } \\
\text { Nr Priest } \\
\text { Rpds Dm }\end{array}$ & $\begin{array}{c}9 / 11 / 84 \\
0: 00\end{array}$ & 46.63999 & -119.7317 & River_or_stream & -129.50 & -17.05 & 6.90 & USGS & 48 \\
\hline CK_ 4221 & $\begin{array}{c}\text { Columbia } \mathrm{R} \\
\text { At Vernita } \mathrm{Br} \\
\text { Nr Priest } \\
\text { Rpds Dm }\end{array}$ & $\begin{array}{c}3 / 26 / 85 \\
0: 00\end{array}$ & 46.63999 & -119.7317 & River_or_stream & -137.50 & -18.05 & 6.90 & USGS & 48 \\
\hline CK_4226 & $\begin{array}{c}\text { Columbia } \mathrm{R} \\
\text { At Vernita } \mathrm{Br} \\
\text { Nr Priest } \\
\text { Rpds Dm }\end{array}$ & $\begin{array}{c}1 / 21 / 86 \\
0: 00\end{array}$ & 46.63999 & -119.7317 & River_or_stream & -133.30 & -17.56 & 7.18 & USGS & 48 \\
\hline CK 4219 & $\begin{array}{c}\text { Columbia R } \\
\text { At Vernita Br } \\
\text { Nr Priest } \\
\text { Rpds Dm }\end{array}$ & $\begin{array}{c}11 / 14 / 84 \\
0: 00\end{array}$ & 46.63999 & -119.7317 & River_or_stream & -131.00 & -17.30 & 7.40 & USGS & 48 \\
\hline CK 4229 & $\begin{array}{c}\text { Columbia } \mathrm{R} \\
\text { At Vernita } \mathrm{Br} \\
\text { Nr Priest } \\
\text { Rpds Dm }\end{array}$ & $\begin{array}{c}7 / 21 / 86 \\
0: 00\end{array}$ & 46.63999 & -119.7317 & River or stream & -127.50 & -16.88 & 7.54 & USGS & 48 \\
\hline CK 4233 & $\begin{array}{c}\text { Columbia R } \\
\text { At Vernita Br } \\
\text { Nr Priest } \\
\text { Rpds Dm }\end{array}$ & $\begin{array}{c}3 / 10 / 87 \\
0: 00\end{array}$ & 46.63999 & -119.7317 & River or stream & -133.80 & -17.67 & 7.56 & USGS & 48 \\
\hline CK 4227 & $\begin{array}{c}\text { Columbia } \mathrm{R} \\
\text { At Vernita } \mathrm{Br} \\
\text { Nr Priest } \\
\text { Rpds Dm }\end{array}$ & $\begin{array}{c}3 / 12 / 86 \\
0: 00\end{array}$ & 46.63999 & -119.7317 & River_or_stream & -133.70 & -17.66 & 7.58 & USGS & 48 \\
\hline CK_4230 & $\begin{array}{c}\text { Columbia R } \\
\text { At Vernita Br } \\
\text { Nr Priest } \\
\text { Rpds Dm }\end{array}$ & $\begin{array}{c}9 / 25 / 86 \\
0: 00\end{array}$ & 46.63999 & -119.7317 & River or stream & -132.40 & -17.50 & 7.60 & USGS & 48 \\
\hline CK_4236 & $\begin{array}{l}\text { Columbia } \mathrm{R} \\
\text { At Vernita } \mathrm{Br}\end{array}$ & $\begin{array}{c}9 / 2 / 87 \\
0: 00\end{array}$ & 46.63999 & -119.7317 & River_or_stream & -130.30 & -17.25 & 7.70 & USGS & 48 \\
\hline
\end{tabular}




\begin{tabular}{|c|c|c|c|c|c|c|c|c|c|c|}
\hline & $\begin{array}{l}\text { Nr Priest } \\
\text { Rpds Dm }\end{array}$ & & & & & & & & & \\
\hline CK_4232 & $\begin{array}{c}\text { Columbia R } \\
\text { At Vernita Br } \\
\text { Nr Priest } \\
\text { Rpds Dm }\end{array}$ & $\begin{array}{c}1 / 21 / 87 \\
0: 00 \\
\end{array}$ & 46.63999 & -119.7317 & River_or_stream & -130.80 & -17.35 & 8.00 & USGS & 48 \\
\hline CK_4235 & $\begin{array}{c}\text { Columbia R } \\
\text { At Vernita Br } \\
\text { Nr Priest } \\
\text { Rpds Dm } \\
\end{array}$ & $\begin{array}{c}7 / 7 / 87 \\
0: 00 \\
\end{array}$ & 46.63999 & -119.7317 & River_or_stream & -125.80 & -16.73 & 8.04 & USGS & 48 \\
\hline CK_4222 & $\begin{array}{c}\text { Columbia R } \\
\text { At Vernita Br } \\
\text { Nr Priest } \\
\text { Rpds Dm }\end{array}$ & $\begin{array}{c}5 / 28 / 85 \\
0: 00 \\
\end{array}$ & 46.63999 & -119.7317 & River_or_stream & -126.00 & -16.76 & 8.08 & USGS & 48 \\
\hline CK_4223 & $\begin{array}{c}\text { Columbia R } \\
\text { At Vernita Br } \\
\text { Nr Priest } \\
\text { Rpds Dm }\end{array}$ & $\begin{array}{c}7 / 29 / 85 \\
0: 00 \\
\end{array}$ & 46.63999 & -119.7317 & River_or_stream & -126.90 & -16.88 & 8.14 & USGS & 48 \\
\hline CK_4228 & $\begin{array}{c}\text { Columbia R } \\
\text { At Vernita Br } \\
\text { Nr Priest } \\
\text { Rpds Dm }\end{array}$ & $\begin{array}{c}5 / 27 / 86 \\
0: 00 \\
\end{array}$ & 46.63999 & -119.7317 & River_or_stream & -125.30 & -16.76 & 8.78 & USGS & 48 \\
\hline CK_4240 & $\begin{array}{c}\text { Columbia } \\
\text { River At } \\
\text { Richland }\end{array}$ & $\begin{array}{c}7 / 30 / 85 \\
0: 00\end{array}$ & 46.31278 & -119.2578 & River_or_stream & -128.00 & -16.74 & 5.92 & USGS & 48 \\
\hline CK_4242 & $\begin{array}{c}\text { Columbia } \\
\text { River At } \\
\text { Richland } \\
\end{array}$ & $\begin{array}{c}3 / 12 / 86 \\
0: 00 \\
\end{array}$ & 46.31278 & -119.2578 & River_or_stream & -134.10 & -17.63 & 6.94 & USGS & 48 \\
\hline CK_4244 & $\begin{array}{c}\text { Columbia } \\
\text { River At } \\
\text { Richland }\end{array}$ & $\begin{array}{c}3 / 9 / 87 \\
0: 00\end{array}$ & 46.31278 & -119.2578 & River_or_stream & -134.80 & -17.74 & 7.12 & USGS & 48 \\
\hline CK_4245 & $\begin{array}{c}\text { Columbia } \\
\text { River At } \\
\text { Richland } \\
\end{array}$ & $\begin{array}{c}5 / 20 / 87 \\
0: 00 \\
\end{array}$ & 46.31278 & -119.2578 & River_or_stream & -125.90 & -16.64 & 7.22 & USGS & 48 \\
\hline CK_4237 & $\begin{array}{l}\text { Columbia } \\
\text { River At } \\
\text { Richland }\end{array}$ & $\begin{array}{c}11 / 15 / 84 \\
0: 00\end{array}$ & 46.31278 & -119.2578 & River_or_stream & -130.70 & -17.25 & 7.30 & USGS & 48 \\
\hline CK_4241 & $\begin{array}{c}\text { Columbia } \\
\text { River At } \\
\text { Richland } \\
\end{array}$ & $\begin{array}{c}12 / 18 / 85 \\
0: 00\end{array}$ & 46.31278 & -119.2578 & River_or_stream & -129.80 & -17.14 & 7.32 & USGS & 48 \\
\hline CK_4246 & $\begin{array}{c}\text { Columbia } \\
\text { River At } \\
\text { Richland }\end{array}$ & $\begin{array}{c}7 / 8 / 87 \\
0: 00 \\
\end{array}$ & 46.31278 & -119.2578 & River_or_stream & -125.80 & -16.64 & 7.32 & USGS & 48 \\
\hline CK_4243 & $\begin{array}{l}\text { Columbia } \\
\text { River At } \\
\text { Richland }\end{array}$ & $\begin{array}{c}5 / 28 / 86 \\
0: 00 \\
\end{array}$ & 46.31278 & -119.2578 & River_or_stream & -126.50 & -16.77 & 7.66 & USGS & 48 \\
\hline CK_4239 & $\begin{array}{c}\text { Columbia } \\
\text { River At } \\
\text { Richland }\end{array}$ & $\begin{array}{c}5 / 29 / 85 \\
0: 00\end{array}$ & 46.31278 & -119.2578 & River_or_stream & -125.00 & -16.61 & 7.88 & USGS & 48 \\
\hline
\end{tabular}




\begin{tabular}{|c|c|c|c|c|c|c|c|c|c|c|c|}
\hline CK_4238 & $\begin{array}{c}\text { Columbia } \\
\text { River At } \\
\text { Richland } \\
\end{array}$ & $\begin{array}{c}3 / 27 / 85 \\
0: 00 \\
\end{array}$ & 46.31278 & -119.2578 & & River_or_stream & -136.00 & -18.06 & 8.48 & USGS & 48 \\
\hline 710866 & Grimes & $\begin{array}{c}8 / 16 / 07 \\
0: 00\end{array}$ & 47.7286971 & -119.5926 & 559.27 & Lake & -73.58 & -5.10 & $\begin{array}{c}- \\
32.78\end{array}$ & EPA_Corvallis & 10 \\
\hline $\begin{array}{c}\text { NRSA0809- } \\
1912\end{array}$ & $\begin{array}{l}\text { Little Bridge } \\
\text { Creek }\end{array}$ & $\begin{array}{c}7 / 16 / 09 \\
0: 00\end{array}$ & 48.3849995 & $\begin{array}{c}- \\
120.29642\end{array}$ & & River_or_stream & -134.00 & -17.44 & 5.49 & EPA & 165 \\
\hline 711100 & Medical Lake & $\begin{array}{c}8 / 30 / 07 \\
0: 00\end{array}$ & 47.5706872 & $\begin{array}{c}- \\
117.68899\end{array}$ & 731.19 & Lake & -61.57 & -4.19 & $\begin{array}{c}- \\
28.05\end{array}$ & EPA_Corvallis & 10 \\
\hline $\begin{array}{c}\text { NRSA0809- } \\
1905\end{array}$ & Methow River & $\begin{array}{c}7 / 15 / 08 \\
0: 00\end{array}$ & 48.2525067 & $\begin{array}{c}- \\
120.11672\end{array}$ & & River_or_stream & -132.36 & -17.54 & 7.94 & EPA & 165 \\
\hline $\begin{array}{c}\text { NRSA0809- } \\
1916\end{array}$ & Mill Creek & $\begin{array}{c}8 / 19 / 09 \\
0: 00\end{array}$ & 46.0652538 & $\begin{array}{c}- \\
118.38026\end{array}$ & & River_or_stream & -102.48 & -13.34 & 4.28 & EPA & 165 \\
\hline $\begin{array}{c}17- \\
040 \_7322\end{array}$ & MMB138 & $\begin{array}{c}8 / 12 / 16 \\
0: 00\end{array}$ & 47.66228 & $\begin{array}{c}- \\
117.41089\end{array}$ & 571.5 & River_or_stream & -109.76 & -14.54 & 6.55 & SPATIAL & 98 \\
\hline $\begin{array}{c}17- \\
040 \_7327\end{array}$ & MMB143 & $\begin{array}{c}8 / 12 / 16 \\
0: 00\end{array}$ & 46.978086 & $\begin{array}{c}- \\
120.56742 \\
\end{array}$ & 458.2 & River_or_stream & -94.91 & -12.96 & 8.73 & SPATIAL & 98 \\
\hline $\begin{array}{c}17- \\
040 \quad 7376\end{array}$ & MMB192 & $\begin{array}{c}8 / 21 / 16 \\
0: 00\end{array}$ & 48.360019 & $\begin{array}{c}- \\
119.58147\end{array}$ & 248.5 & River_or_stream & -113.17 & -13.90 & -1.97 & SPATIAL & 98 \\
\hline $\begin{array}{c}17- \\
040 \quad 7378\end{array}$ & MMB194 & $\begin{array}{c}8 / 21 / 16 \\
0: 00\end{array}$ & 47.947803 & $\begin{array}{c}- \\
118.98649\end{array}$ & 391.2 & River_or_stream & -127.70 & -16.67 & 5.69 & SPATIAL & 98 \\
\hline $\begin{array}{c}17- \\
040 \_7383\end{array}$ & MMB199 & $\begin{array}{c}8 / 22 / 16 \\
0: 00\end{array}$ & 48.342915 & -120.7003 & 392.4 & River or stream & -116.17 & -15.35 & 6.67 & SPATIAL & 98 \\
\hline $\begin{array}{c}17- \\
040 \quad 7384\end{array}$ & MMB200 & $\begin{array}{c}8 / 22 / 16 \\
0: 00 \\
\end{array}$ & 48.334671 & $\begin{array}{c}- \\
120.69314 \\
\end{array}$ & 350.5 & River_or_stream & -111.40 & -15.17 & 9.98 & SPATIAL & 98 \\
\hline $\begin{array}{c}17- \\
040 \quad 7387\end{array}$ & MMB203 & $\begin{array}{c}8 / 22 / 16 \\
0: 00\end{array}$ & 47.458426 & -120.3326 & 189.1 & River_or_stream & -106.14 & -14.28 & 8.12 & SPATIAL & 98 \\
\hline $\begin{array}{c}17- \\
040 \_7388\end{array}$ & MMB204 & $\begin{array}{c}8 / 22 / 16 \\
0: 00\end{array}$ & 47.425198 & -120.3057 & 188.6 & River_or_stream & -128.37 & -16.86 & 6.48 & SPATIAL & 98 \\
\hline $\begin{array}{c}17- \\
040 \quad 7391\end{array}$ & MMB207 & $\begin{array}{c}8 / 23 / 16 \\
0: 00\end{array}$ & 46.22213 & $\begin{array}{c}- \\
119.13844\end{array}$ & 103.7 & River_or_stream & -128.24 & -16.91 & 7.07 & SPATIAL & 98 \\
\hline $\begin{array}{c}17- \\
040 \_7392\end{array}$ & MMB208 & $\begin{array}{c}8 / 23 / 16 \\
0: 00\end{array}$ & 46.0596 & $\begin{array}{c}- \\
118.90857\end{array}$ & 104.3 & River_or_stream & -120.01 & -15.47 & 3.75 & SPATIAL & 98 \\
\hline $\begin{array}{c}17- \\
040 \quad 7394\end{array}$ & MMB210 & $\begin{array}{c}8 / 23 / 16 \\
0: 00 \\
\end{array}$ & 46.318185 & $\begin{array}{c}- \\
117.98267\end{array}$ & 488.6 & River_or_stream & -108.18 & -14.63 & 8.89 & SPATIAL & 98 \\
\hline $\begin{array}{c}17- \\
040 \quad 7396\end{array}$ & MMB212 & $\begin{array}{c}8 / 24 / 16 \\
0: 00\end{array}$ & 46.363189 & $\begin{array}{c}- \\
117.06056\end{array}$ & 225.7 & River_or_stream & -117.66 & -14.79 & 0.65 & SPATIAL & 98 \\
\hline 711132 & Moses Lake & $\begin{array}{c}9 / 4 / 07 \\
0: 00\end{array}$ & 47.1844144 & $\begin{array}{c}- \\
119.36398\end{array}$ & 320.11 & Lake & -117.48 & -14.58 & -0.82 & EPA_Corvallis & 10 \\
\hline CK_4204 & $\begin{array}{c}\text { Okanogan } \\
\text { River At } \\
\text { Malott }\end{array}$ & $\begin{array}{c}8 / 14 / 86 \\
0: 00\end{array}$ & 48.28055 & -119.703 & 240.79 & River_or_stream & -109.90 & -13.27 & -3.74 & USGS & 48 \\
\hline CK_4205 & $\begin{array}{c}\text { Okanogan } \\
\text { River At } \\
\text { Malott }\end{array}$ & $\begin{array}{c}10 / 6 / 86 \\
0: 00 \\
\end{array}$ & 48.28055 & -119.703 & 240.79 & River_or_stream & -109.30 & -13.24 & -3.38 & USGS & 48 \\
\hline CK_4201 & $\begin{array}{c}\text { Okanogan } \\
\text { River At } \\
\text { Malott }\end{array}$ & $\begin{array}{c}2 / 4 / 85 \\
0: 00\end{array}$ & 48.28055 & -119.703 & 240.79 & River_or_stream & -118.50 & -14.60 & -1.70 & USGS & 48 \\
\hline
\end{tabular}




\begin{tabular}{|c|c|c|c|c|c|c|c|c|c|c|c|}
\hline CK 4203 & $\begin{array}{c}\text { Okanogan } \\
\text { River At } \\
\text { Malott }\end{array}$ & $\begin{array}{c}8 / 5 / 85 \\
0: 00\end{array}$ & 48.28055 & -119.703 & 240.79 & River_or_stream & -117.60 & -14.69 & -0.08 & USGS & 48 \\
\hline CK_4200 & $\begin{array}{c}\text { Okanogan } \\
\text { River At } \\
\text { Malott }\end{array}$ & $\begin{array}{c}10 / 17 / 84 \\
0: 00 \\
\end{array}$ & 48.28055 & -119.703 & 240.79 & River_or_stream & -116.50 & -14.70 & 1.10 & USGS & 48 \\
\hline CK_4206 & $\begin{array}{c}\text { Okanogan } \\
\text { River At } \\
\text { Malott }\end{array}$ & $\begin{array}{c}10 / 8 / 86 \\
0: 00\end{array}$ & 48.28055 & -119.703 & 240.79 & River_or_stream & -115.60 & -14.61 & 1.28 & USGS & 48 \\
\hline CK_4209 & $\begin{array}{c}\text { Okanogan } \\
\text { River At } \\
\text { Malott }\end{array}$ & $\begin{array}{c}8 / 6 / 87 \\
0: 00\end{array}$ & 48.28055 & -119.703 & 240.79 & River_or_stream & -113.60 & -14.36 & 1.28 & USGS & 48 \\
\hline CK_4207 & $\begin{array}{c}\text { Okanogan } \\
\text { River At } \\
\text { Malott }\end{array}$ & $\begin{array}{c}2 / 3 / 87 \\
0: 00 \\
\end{array}$ & 48.28055 & -119.703 & 240.79 & River_or_stream & -118.20 & -15.07 & 2.36 & USGS & 48 \\
\hline CK_4202 & $\begin{array}{c}\text { Okanogan } \\
\text { River At } \\
\text { Malott }\end{array}$ & $\begin{array}{c}6 / 6 / 85 \\
0: 00\end{array}$ & 48.28055 & -119.703 & 240.79 & River or stream & -123.60 & -16.36 & 7.28 & USGS & 48 \\
\hline CK 4208 & $\begin{array}{c}\text { Okanogan } \\
\text { River At } \\
\text { Malott }\end{array}$ & $\begin{array}{c}6 / 17 / 87 \\
0: 00\end{array}$ & 48.28055 & -119.703 & 240.79 & River_or_stream & -118.70 & -15.78 & 7.54 & USGS & 48 \\
\hline $\begin{array}{c}\text { NRSA0809- } \\
1888\end{array}$ & $\begin{array}{l}\text { Peshastin } \\
\text { Creek }\end{array}$ & $\begin{array}{c}7 / 16 / 08 \\
0: 00\end{array}$ & 47.4628839 & $\begin{array}{c}- \\
120.66107\end{array}$ & & River_or_stream & -114.81 & -15.03 & 5.46 & EPA & 165 \\
\hline $\begin{array}{l}\text { NRSA0809- } \\
2252\end{array}$ & $\begin{array}{l}\text { Peshastin } \\
\text { Creek }\end{array}$ & $\begin{array}{c}9 / 28 / 09 \\
0: 00\end{array}$ & 47.4628839 & $\begin{array}{c}- \\
120.66107\end{array}$ & & River_or_stream & -114.10 & -15.53 & 10.17 & EPA & 165 \\
\hline 711214 & $\begin{array}{l}\text { Red Rock } \\
\text { Lake }\end{array}$ & $\begin{array}{c}9 / 12 / 07 \\
0: 00\end{array}$ & 46.8713894 & $\begin{array}{c}- \\
119.57087\end{array}$ & 210.96 & Lake & -123.02 & -15.75 & 2.99 & EPA_Corvallis & 10 \\
\hline 711242 & $\begin{array}{c}\text { Saddle } \\
\text { Mountain } \\
\text { Lake }\end{array}$ & $\begin{array}{c}9 / 13 / 07 \\
0: 00\end{array}$ & 46.6934672 & 119.64832 & 149.07 & Lake & -111.43 & -13.57 & -2.89 & EPA_Corvallis & 10 \\
\hline CK_ 4401 & $\begin{array}{l}\text { Snake River } \\
\text { At Burbank }\end{array}$ & $\begin{array}{c}3 / 11 / 87 \\
0: 00\end{array}$ & 46.21638 & -119.0228 & & River_or_stream & -127.60 & -16.44 & 3.92 & USGS & 48 \\
\hline CK 4403 & $\begin{array}{l}\text { Snake River } \\
\text { At Burbank }\end{array}$ & $\begin{array}{c}8 / 19 / 87 \\
0: 00\end{array}$ & 46.21638 & -119.0228 & & River_or_stream & -119.70 & -15.63 & 5.34 & USGS & 48 \\
\hline CK_4395 & $\begin{array}{l}\text { Snake River } \\
\text { At Burbank }\end{array}$ & $\begin{array}{c}11 / 26 / 85 \\
0: 00\end{array}$ & 46.21638 & -119.0228 & & River_or_stream & -121.90 & -15.95 & 5.70 & USGS & 48 \\
\hline CK_ 4400 & $\begin{array}{l}\text { Snake River } \\
\text { At Burbank }\end{array}$ & $\begin{array}{c}11 / 10 / 86 \\
0: 00\end{array}$ & 46.21638 & -119.0228 & & River_or_stream & -123.20 & -16.12 & 5.76 & USGS & 48 \\
\hline CK 4393 & $\begin{array}{l}\text { Snake River } \\
\text { At Burbank }\end{array}$ & $\begin{array}{c}2 / 9 / 85 \\
0: 00\end{array}$ & 46.21638 & -119.0228 & & River_or_stream & -125.00 & -16.40 & 6.20 & USGS & 48 \\
\hline CK_4402 & $\begin{array}{l}\text { Snake River } \\
\text { At Burbank }\end{array}$ & $\begin{array}{c}4 / 28 / 87 \\
0: 00\end{array}$ & 46.21638 & -119.0228 & & River_or_stream & -122.30 & -16.09 & 6.42 & USGS & 48 \\
\hline CK_4396 & $\begin{array}{l}\text { Snake River } \\
\text { At Burbank }\end{array}$ & $\begin{array}{c}3 / 10 / 86 \\
0: 00\end{array}$ & 46.21638 & -119.0228 & & River_or_stream & -122.20 & -16.10 & 6.60 & USGS & 48 \\
\hline CK_4392 & $\begin{array}{l}\text { Snake River } \\
\text { At Burbank }\end{array}$ & $\begin{array}{c}11 / 19 / 84 \\
0: 00\end{array}$ & 46.21638 & -119.0228 & & River_or_stream & -122.00 & -16.15 & 7.20 & USGS & 48 \\
\hline CK 4397 & $\begin{array}{l}\text { Snake River } \\
\text { At Burbank }\end{array}$ & $\begin{array}{c}5 / 8 / 86 \\
0: 00\end{array}$ & 46.21638 & -119.0228 & & River_or_stream & -124.60 & -16.48 & 7.24 & USGS & 48 \\
\hline
\end{tabular}




\begin{tabular}{|c|c|c|c|c|c|c|c|c|c|c|c|}
\hline CK_4399 & $\begin{array}{l}\text { Snake River } \\
\text { At Burbank }\end{array}$ & $\begin{array}{c}8 / 12 / 86 \\
0: 00 \\
\end{array}$ & 46.21638 & -119.0228 & & River_or_stream & -122.70 & -16.38 & 8.34 & USGS & 48 \\
\hline CK_4398 & $\begin{array}{l}\text { Snake River } \\
\text { At Burbank }\end{array}$ & $\begin{array}{c}5 / 28 / 86 \\
0: 00 \\
\end{array}$ & 46.21638 & -119.0228 & & River_or_stream & -123.20 & -16.47 & 8.56 & USGS & 48 \\
\hline CK_4394 & $\begin{array}{l}\text { Snake River } \\
\text { At Burbank }\end{array}$ & $\begin{array}{c}5 / 21 / 85 \\
0: 00\end{array}$ & 46.21638 & -119.0228 & & River_or_stream & -123.10 & -16.70 & 10.50 & USGS & 48 \\
\hline $\begin{array}{c}\text { NRSA0809- } \\
1906 \\
\end{array}$ & $\begin{array}{c}\text { Snake River } \\
\text { near Granite } \\
\text { Dam }\end{array}$ & $\begin{array}{c}9 / 25 / 09 \\
0: 00 \\
\end{array}$ & 46.6559853 & $\begin{array}{c}- \\
117.41411 \\
\end{array}$ & & River_or_stream & -122.30 & -15.83 & 4.37 & EPA & 165 \\
\hline & $\begin{array}{c}\text { Snake River } \\
\text { near Granite } \\
\text { Dam }\end{array}$ & & 46.6559853 & $\begin{array}{c}- \\
117.41411\end{array}$ & & Stream/River & -122.30 & -15.83 & 4.37 & EPA & 165 \\
\hline $\begin{array}{c}\text { NRSA0809- } \\
1908 \\
\end{array}$ & $\begin{array}{c}\text { Spokane } \\
\text { River }\end{array}$ & $\begin{array}{c}9 / 9 / 08 \\
0: 00 \\
\end{array}$ & 47.6798164 & $\begin{array}{c}- \\
117.21719\end{array}$ & & River_or_stream & -110.13 & -14.82 & 8.41 & EPA & 165 \\
\hline CK_4194 & $\begin{array}{c}\text { Spokane } \\
\text { River At Long } \\
\text { Lake }\end{array}$ & $\begin{array}{c}9 / 4 / 85 \\
0: 00 \\
\end{array}$ & 47.83833 & -117.8514 & 395.94 & River_or_stream & -112.30 & -14.67 & 5.06 & USGS & 48 \\
\hline CK_4189 & $\begin{array}{c}\text { Spokane } \\
\text { River At Long } \\
\text { Lake }\end{array}$ & $\begin{array}{c}9 / 13 / 84 \\
0: 00 \\
\end{array}$ & 47.83833 & -117.8514 & 395.94 & River_or_stream & -110.00 & -14.40 & 5.20 & USGS & 48 \\
\hline CK_4199 & $\begin{array}{c}\text { Spokane } \\
\text { River At Long } \\
\text { Lake }\end{array}$ & $\begin{array}{c}9 / 2 / 86 \\
0: 00 \\
\end{array}$ & 47.83833 & -117.8514 & 395.94 & River_or_stream & -109.90 & -14.52 & 6.26 & USGS & 48 \\
\hline CK_4193 & $\begin{array}{c}\text { Spokane } \\
\text { River At Long } \\
\text { Lake }\end{array}$ & $\begin{array}{c}7 / 10 / 85 \\
0: 00 \\
\end{array}$ & 47.83833 & -117.8514 & 395.94 & River_or_stream & -111.70 & -14.79 & 6.62 & USGS & 48 \\
\hline CK_4190 & $\begin{array}{c}\text { Spokane } \\
\text { River At Long } \\
\text { Lake }\end{array}$ & $\begin{array}{c}11 / 15 / 84 \\
0: 00 \\
\end{array}$ & 47.83833 & -117.8514 & 395.94 & River_or_stream & -109.00 & -14.50 & 7.00 & USGS & 48 \\
\hline CK_4195 & $\begin{array}{c}\text { Spokane } \\
\text { River At Long } \\
\text { Lake } \\
\end{array}$ & $\begin{array}{c}11 / 21 / 85 \\
0: 00 \\
\end{array}$ & 47.83833 & -117.8514 & 395.94 & River_or_stream & -110.80 & -14.74 & 7.12 & USGS & 48 \\
\hline CK_4196 & $\begin{array}{c}\text { Spokane } \\
\text { River At Long } \\
\text { Lake }\end{array}$ & $\begin{array}{c}1 / 13 / 86 \\
0: 00\end{array}$ & 47.83833 & -117.8514 & 395.94 & River_or_stream & -110.50 & -14.77 & 7.66 & USGS & 48 \\
\hline CK_4197 & $\begin{array}{c}\text { Spokane } \\
\text { River At Long } \\
\text { Lake }\end{array}$ & $\begin{array}{c}3 / 5 / 86 \\
0: 00 \\
\end{array}$ & 47.83833 & -117.8514 & 395.94 & River_or_stream & -111.00 & -14.88 & 8.04 & USGS & 48 \\
\hline CK_4198 & $\begin{array}{c}\text { Spokane } \\
\text { River At Long } \\
\text { Lake }\end{array}$ & $\begin{array}{c}7 / 17 / 86 \\
0: 00 \\
\end{array}$ & 47.83833 & -117.8514 & 395.94 & River_or_stream & -109.30 & -14.67 & 8.06 & USGS & 48 \\
\hline CK_4191 & $\begin{array}{c}\text { Spokane } \\
\text { River At Long } \\
\text { Lake }\end{array}$ & $\begin{array}{c}1 / 16 / 85 \\
0: 00 \\
\end{array}$ & 47.83833 & -117.8514 & 395.94 & River_or_stream & -111.00 & -14.90 & 8.20 & USGS & 48 \\
\hline CK_4192 & $\begin{array}{c}\text { Spokane } \\
\text { River At Long } \\
\text { Lake }\end{array}$ & $\begin{array}{c}5 / 28 / 85 \\
0: 00\end{array}$ & 47.83833 & -117.8514 & 395.94 & River_or_stream & -110.40 & -15.02 & 9.76 & USGS & 48 \\
\hline $\begin{array}{l}\text { NRSA0809- } \\
1895\end{array}$ & $\begin{array}{c}\text { Touchet } \\
\text { River }\end{array}$ & $\begin{array}{c}7 / 23 / 08 \\
0: 00\end{array}$ & 46.2761707 & $\begin{array}{c}- \\
118.19248\end{array}$ & & River_or_stream & -106.73 & -14.32 & 7.83 & EPA & 165 \\
\hline
\end{tabular}




\begin{tabular}{|c|c|c|c|c|c|c|c|c|c|c|c|}
\hline $\begin{array}{c}\text { NRSA0809- } \\
1899\end{array}$ & $\begin{array}{c}\text { Trail Lake } \\
\text { Coullee }\end{array}$ & $\begin{array}{c}\text { 8/19/08 } \\
0: 00\end{array}$ & 47.5038301 & $\begin{array}{c}- \\
119.29244\end{array}$ & & River_or_stream & -125.02 & -16.29 & 5.28 & EPA & 165 \\
\hline $\begin{array}{l}\text { NRSA0809- } \\
1887\end{array}$ & $\begin{array}{l}\text { Twentyfive } \\
\text { Mile Creek }\end{array}$ & $\begin{array}{c}8 / 13 / 08 \\
0: 00 \\
\end{array}$ & 47.934476 & $\begin{array}{c}- \\
120.30671\end{array}$ & & River_or_stream & -125.57 & -17.01 & 10.52 & EPA & 165 \\
\hline $\begin{array}{c}\text { NRSA0809- } \\
1918\end{array}$ & $\begin{array}{c}\text { Unnamed } \\
\text { Tributary } \\
\text { near Mount } \\
\text { Spokane }\end{array}$ & $\begin{array}{c}7 / 21 / 09 \\
0: 00\end{array}$ & 47.9474663 & $\begin{array}{c}- \\
117.10503\end{array}$ & & River_or_stream & -114.76 & -15.68 & 10.65 & EPA & 165 \\
\hline $\begin{array}{l}\text { NRSA0809- } \\
1578\end{array}$ & $\begin{array}{c}\text { Wanatchee } \\
\text { River }\end{array}$ & $\begin{array}{c}7 / 27 / 09 \\
0: 00\end{array}$ & 47.6919568 & $\begin{array}{c}- \\
120.71093\end{array}$ & & River_or_stream & -112.50 & -15.18 & 8.93 & EPA & 165 \\
\hline $\begin{array}{l}\text { NRSA0809- } \\
1910\end{array}$ & Yakima River & $\begin{array}{c}10 / 22 / 09 \\
0: 00\end{array}$ & 46.4044218 & $\begin{array}{c}- \\
120.28959\end{array}$ & & River_or_stream & -99.38 & -13.48 & 8.46 & EPA & 165 \\
\hline CK 4253 & $\begin{array}{c}\text { Yakima River } \\
\text { Abv Ahtanum } \\
\text { Cr At Union } \\
\text { Gap }\end{array}$ & $\begin{array}{c}9 / 17 / 85 \\
0: 00\end{array}$ & 46.53444 & -120.4661 & 274.32 & River or stream & -100.60 & -13.41 & 6.68 & USGS & 48 \\
\hline CK_ 4262 & $\begin{array}{c}\text { Yakima River } \\
\text { Abv Ahtanum } \\
\text { Cr At Union } \\
\text { Gap }\end{array}$ & $\begin{array}{c}8 / 11 / 87 \\
0: 00\end{array}$ & 46.53444 & -120.4661 & 274.32 & River_or_stream & -97.60 & -13.05 & 6.80 & USGS & 48 \\
\hline CK 4263 & $\begin{array}{c}\text { Yakima River } \\
\text { Abv Ahtanum } \\
\text { Cr At Union } \\
\text { Gap }\end{array}$ & $\begin{array}{c}9 / 10 / 87 \\
0: 00\end{array}$ & 46.53444 & -120.4661 & 274.32 & River_or stream & -98.00 & -13.11 & 6.88 & USGS & 48 \\
\hline CK 4254 & $\begin{array}{c}\text { Yakima River } \\
\text { Abv Ahtanum } \\
\text { Cr At Union } \\
\text { Gap }\end{array}$ & $\begin{array}{c}11 / 5 / 85 \\
0: 00\end{array}$ & 46.53444 & -120.4661 & 274.32 & River_or_stream & -99.90 & -13.38 & 7.14 & USGS & 48 \\
\hline CK 4255 & $\begin{array}{c}\text { Yakima River } \\
\text { Abv Ahtanum } \\
\text { Cr At Union } \\
\text { Gap }\end{array}$ & $\begin{array}{c}1 / 27 / 86 \\
0: 00\end{array}$ & 46.53444 & -120.4661 & 274.32 & River or stream & -105.70 & -14.13 & 7.34 & USGS & 48 \\
\hline CK_4250 & $\begin{array}{c}\text { Yakima River } \\
\text { Abv Ahtanum } \\
\text { Cr At Union } \\
\text { Gap }\end{array}$ & $\begin{array}{c}3 / 13 / 85 \\
0: 00\end{array}$ & 46.53444 & -120.4661 & 274.32 & River_or_stream & -106.00 & -14.20 & 7.60 & USGS & 48 \\
\hline CK 4258 & $\begin{array}{c}\text { Yakima River } \\
\text { Abv Ahtanum } \\
\text { Cr At Union } \\
\text { Gap }\end{array}$ & $\begin{array}{c}11 / 5 / 86 \\
0: 00\end{array}$ & 46.53444 & -120.4661 & 274.32 & River_or_stream & -102.30 & -13.79 & 8.02 & USGS & 48 \\
\hline CK 4248 & $\begin{array}{c}\text { Yakima River } \\
\text { Abv Ahtanum } \\
\text { Cr At Union } \\
\text { Gap }\end{array}$ & $\begin{array}{c}11 / 8 / 84 \\
0: 00\end{array}$ & 46.53444 & -120.4661 & 274.32 & River_or_stream & -103.00 & -13.90 & 8.20 & USGS & 48 \\
\hline CK_4261 & $\begin{array}{c}\text { Yakima River } \\
\text { Abv Ahtanum } \\
\text { Cr At Union } \\
\text { Gap }\end{array}$ & $\begin{array}{c}5 / 14 / 87 \\
0: 00 \\
\end{array}$ & 46.53444 & -120.4661 & 274.32 & River_or_stream & -103.90 & -14.08 & 8.74 & USGS & 48 \\
\hline CK_4249 & $\begin{array}{l}\text { Yakima River } \\
\text { Abv Ahtanum }\end{array}$ & $\begin{array}{c}1 / 8 / 85 \\
0: 00\end{array}$ & 46.53444 & -120.4661 & 274.32 & River_or_stream & -103.50 & -14.05 & 8.90 & USGS & 48 \\
\hline
\end{tabular}




\begin{tabular}{|c|c|c|c|c|c|c|c|c|c|c|c|}
\hline & $\begin{array}{c}\text { Cr At Union } \\
\text { Gap }\end{array}$ & & & & & & & & & & \\
\hline CK 4257 & $\begin{array}{c}\text { Yakima River } \\
\text { Abv Ahtanum } \\
\text { Cr At Union } \\
\text { Gap }\end{array}$ & $\begin{array}{c}9 / 22 / 86 \\
0: 00\end{array}$ & 46.53444 & -120.4661 & 274.32 & River or stream & -98.80 & -13.48 & 9.04 & USGS & 48 \\
\hline CK_4259 & $\begin{array}{c}\text { Yakima River } \\
\text { Abv Ahtanum } \\
\text { Cr At Union } \\
\text { Gap }\end{array}$ & $\begin{array}{c}2 / 6 / 87 \\
0: 00\end{array}$ & 46.53444 & -120.4661 & 274.32 & River_or stream & -103.40 & -14.06 & 9.08 & USGS & 48 \\
\hline CK 4260 & $\begin{array}{c}\text { Yakima River } \\
\text { Abv Ahtanum } \\
\text { Cr At Union } \\
\text { Gap }\end{array}$ & $\begin{array}{c}3 / 25 / 87 \\
0: 00\end{array}$ & 46.53444 & -120.4661 & 274.32 & River or stream & -104.20 & -14.16 & 908 & USGS & 48 \\
\hline CK 4256 & $\begin{array}{c}\text { Yakima River } \\
\text { Abv Ahtanum } \\
\text { Cr At Union } \\
\text { Gap }\end{array}$ & $\begin{array}{c}5 / 10 / 86 \\
0: 00\end{array}$ & 46.53444 & -120.4661 & 274.32 & River or stream & -103.70 & -14.24 & 10.22 & USGS & 48 \\
\hline CK_4252 & $\begin{array}{c}\text { Yakima River } \\
\text { Abv Ahtanum } \\
\text { Cr At Union } \\
\text { Gap }\end{array}$ & $\begin{array}{c}7 / 15 / 85 \\
0: 00\end{array}$ & 46.53444 & -120.4661 & 274.32 & River or stream & -100.60 & -13.98 & 11.24 & USGS & 48 \\
\hline CK 4251 & $\begin{array}{c}\text { Yakima River } \\
\text { Abv Ahtanum } \\
\text { Cr At Union } \\
\text { Gap }\end{array}$ & $\begin{array}{c}5 / 8 / 85 \\
0: 00\end{array}$ & 46.53444 & -120.4661 & 274.32 & River or stream & -104.80 & -14.53 & 11.44 & USGS & 48 \\
\hline CK 4247 & $\begin{array}{c}\text { Yakima River } \\
\text { Abv Ahtanum } \\
\text { Cr At Union } \\
\text { Gap }\end{array}$ & $\begin{array}{c}9 / 11 / 84 \\
0: 00\end{array}$ & 46.53444 & -120.4661 & 274.32 & River or stream & -100.00 & -13.95 & 11.60 & USGS & 48 \\
\hline $\begin{array}{l}\text { NRSA0809- } \\
1903\end{array}$ & $\begin{array}{c}\text { Yakima River } \\
\text { at Benton }\end{array}$ & $\begin{array}{c}7 / 22 / 08 \\
0: 00\end{array}$ & 46.2711703 & $\begin{array}{c}- \\
119.57047\end{array}$ & & River or stream & -101.64 & -13.53 & 6.58 & EPA & 165 \\
\hline CK 4281 & $\begin{array}{c}\text { Yakima River } \\
\text { At Kiona }\end{array}$ & $\begin{array}{c}9 / 15 / 87 \\
0: 00\end{array}$ & 46.25361 & -119.4769 & 138.5 & River_or_stream & -100.70 & -13.22 & 5.06 & USGS & 48 \\
\hline CK_4280 & $\begin{array}{c}\text { Yakima River } \\
\text { At Kiona }\end{array}$ & $\begin{array}{c}8 / 20 / 87 \\
0: 00\end{array}$ & 46.25361 & -119.4769 & 138.5 & River_or_stream & -99.30 & -13.15 & 5.90 & USGS & 48 \\
\hline CK 4273 & $\begin{array}{l}\text { Yakima River } \\
\text { At Kiona }\end{array}$ & $\begin{array}{c}3 / 11 / 86 \\
0: 00\end{array}$ & 46.25361 & -119.4769 & 138.5 & River_or_stream & -110.30 & -14.54 & 6.02 & USGS & 48 \\
\hline CK 4272 & $\begin{array}{c}\text { Yakima River } \\
\text { At Kiona }\end{array}$ & $\begin{array}{c}1 / 8 / 86 \\
0: 00\end{array}$ & 46.25361 & -119.4769 & 138.5 & River or stream & -105.10 & -13.99 & 6.82 & USGS & 48 \\
\hline CK 4266 & $\begin{array}{c}\text { Yakima River } \\
\text { At Kiona }\end{array}$ & $\begin{array}{c}1 / 21 / 85 \\
0: 00\end{array}$ & 46.25361 & -119.4769 & 138.5 & River_or stream & -105.00 & -14.00 & 7.00 & USGS & 48 \\
\hline CK_4275 & $\begin{array}{c}\text { Yakima River } \\
\text { At Kiona }\end{array}$ & $\begin{array}{c}9 / 15 / 86 \\
0: 00\end{array}$ & 46.25361 & -119.4769 & 138.5 & River_or_stream & -100.40 & -13.45 & 7.20 & USGS & 48 \\
\hline CK 4276 & $\begin{array}{c}\text { Yakima River } \\
\text { At Kiona }\end{array}$ & $\begin{array}{c}11 / 4 / 86 \\
0: 00\end{array}$ & 46.25361 & -119.4769 & 138.5 & River_or stream & -102.70 & -13.80 & 7.70 & USGS & 48 \\
\hline CK 4270 & $\begin{array}{c}\text { Yakima River } \\
\text { At Kiona }\end{array}$ & $\begin{array}{c}9 / 11 / 85 \\
0: 00\end{array}$ & 46.25361 & -119.4769 & 138.5 & River_or_stream & -99.70 & -13.43 & 7.74 & USGS & 48 \\
\hline
\end{tabular}




\begin{tabular}{|c|c|c|c|c|c|c|c|c|c|c|c|}
\hline CK_4267 & $\begin{array}{c}\text { Yakima River } \\
\text { At Kiona }\end{array}$ & $\begin{array}{c}3 / 11 / 85 \\
0: 00\end{array}$ & 46.25361 & -119.4769 & 138.5 & River_or_stream & -106.50 & -14.30 & 7.90 & USGS & 48 \\
\hline CK_4269 & $\begin{array}{c}\text { Yakima River } \\
\text { At Kiona }\end{array}$ & $\begin{array}{c}7 / 10 / 85 \\
0: 00\end{array}$ & 46.25361 & -119.4769 & 138.5 & River_or_stream & -102.70 & -13.83 & 7.94 & USGS & 48 \\
\hline CK_4279 & $\begin{array}{c}\text { Yakima River } \\
\text { At Kiona }\end{array}$ & $\begin{array}{c}5 / 21 / 87 \\
0: 00\end{array}$ & 46.25361 & -119.4769 & 138.5 & River_or_stream & -101.60 & -13.71 & 8.08 & USGS & 48 \\
\hline CK 4277 & $\begin{array}{c}\text { Yakima River } \\
\text { At Kiona }\end{array}$ & $\begin{array}{c}1 / 20 / 87 \\
0: 00\end{array}$ & 46.25361 & -119.4769 & 138.5 & River_or_stream & -104.60 & -14.10 & 8.20 & USGS & 48 \\
\hline CK_4278 & $\begin{array}{c}\text { Yakima River } \\
\text { At Kiona }\end{array}$ & $\begin{array}{c}3 / 19 / 87 \\
0: 00\end{array}$ & 46.25361 & -119.4769 & 138.5 & River_or_stream & -106.90 & -14.41 & 8.38 & USGS & 48 \\
\hline CK_ 4274 & $\begin{array}{c}\text { Yakima River } \\
\text { At Kiona }\end{array}$ & $\begin{array}{c}7 / 1 / 86 \\
0: 00\end{array}$ & 46.25361 & -119.4769 & 138.5 & River_or_stream & -101.20 & -13.70 & 8.40 & USGS & 48 \\
\hline CK_4271 & $\begin{array}{c}\text { Yakima River } \\
\text { At Kiona }\end{array}$ & $\begin{array}{c}11 / 15 / 85 \\
0: 00 \\
\end{array}$ & 46.25361 & -119.4769 & 138.5 & River_or_stream & -99.60 & -13.56 & 8.88 & USGS & 48 \\
\hline CK 4265 & $\begin{array}{c}\text { Yakima River } \\
\text { At Kiona }\end{array}$ & $\begin{array}{c}11 / 20 / 84 \\
0: 00\end{array}$ & 46.25361 & -119.4769 & 138.5 & River_or_stream & -102.00 & -13.95 & 9.60 & USGS & 48 \\
\hline CK_4268 & $\begin{array}{c}\text { Yakima River } \\
\text { At Kiona }\end{array}$ & $\begin{array}{c}5 / 1 / 85 \\
0: 00\end{array}$ & 46.25361 & -119.4769 & 138.5 & River_or_stream & -102.50 & -14.16 & 10.78 & USGS & 48 \\
\hline CK_4264 & $\begin{array}{c}\text { Yakima River } \\
\text { At Kiona }\end{array}$ & $\begin{array}{c}9 / 10 / 84 \\
0: 00\end{array}$ & 46.25361 & -119.4769 & 138.5 & River_or_stream & -101.00 & & & USGS & 48 \\
\hline
\end{tabular}

Appendix C. Meteoric waters for windward lapse rate determination (WaterIsotopes, 2020; IAEA, 2020).

\begin{tabular}{|c|c|c|c|c|c|c|c|c|c|c|c|c|}
\hline Sample ID & Site Name & $\begin{array}{l}\text { Collection } \\
\text { Date }\end{array}$ & Latitude & Longitude & $\begin{array}{c}\text { Collection } \\
\text { Elevation } \\
\text { (mabsl) }\end{array}$ & $\begin{array}{l}\text { Collection } \\
\text { Elevation } \\
\text { from } \\
\text { Google } \\
\text { Earth (m) }\end{array}$ & Type & $\begin{array}{c}\delta D \\
\text { (per } \\
\text { mille) }\end{array}$ & $\begin{array}{c}\delta^{18} O \\
\text { (per } \\
\text { mille) }\end{array}$ & d & $\begin{array}{l}\text { WI Analysis } \\
\text { Source }\end{array}$ & $\begin{array}{l}\text { Project } \\
\text { ID }\end{array}$ \\
\hline 711059 & Lewis Lake & $\begin{array}{c}8 / 29 / 07 \\
0: 00 \\
\end{array}$ & 46.98630288 & $\begin{array}{c}- \\
122.5690307 \\
\end{array}$ & 108.21 & 107 & Lake & -38.43 & -2.94 & -14.91 & EPA_Corvallis & 10 \\
\hline 711054 & Swamp & $\begin{array}{c}8 / 28 / 07 \\
0: 00 \\
\end{array}$ & 47.31108363 & $\begin{array}{c}- \\
121.2990598 \\
\end{array}$ & 732.43 & 734 & Lake & -72.53 & -8.24 & -6.61 & EPA_Corvallis & 10 \\
\hline 710974 & U Lake & $\begin{array}{c}8 / 21 / 07 \\
0: 00 \\
\end{array}$ & 47.427764 & -123.074122 & 144.98 & 148 & Lake & -50.93 & -5.61 & -6.08 & EPA_Corvallis & 10 \\
\hline 710719 & $\begin{array}{c}\text { Forbes } \\
\text { Lake }\end{array}$ & $\begin{array}{c}8 / 7 / 07 \\
0: 00 \\
\end{array}$ & 47.19204698 & $\begin{array}{c}- \\
122.9725593 \\
\end{array}$ & 30.04 & 30 & Lake & -50.05 & -5.82 & -3.52 & EPA_Corvallis & 10 \\
\hline 710935 & $\begin{array}{c}\text { American } \\
\text { Lake }\end{array}$ & $\begin{array}{c}8 / 21 / 07 \\
0: 00 \\
\end{array}$ & 47.13285576 & $\begin{array}{c}- \\
122.5619208 \\
\end{array}$ & 72.65 & 71 & Lake & -57.73 & -6.90 & -2.56 & EPA_Corvallis & 10 \\
\hline 711006 & $\begin{array}{c}\text { Lake } \\
\text { Koeneman }\end{array}$ & $\begin{array}{c}8 / 24 / 07 \\
0: 00 \\
\end{array}$ & 47.40930776 & $\begin{array}{c}- \\
122.7843969\end{array}$ & 63.56 & 66 & Lake & -58.45 & -7.16 & -1.13 & EPA_Corvallis & 10 \\
\hline 710204 & $\begin{array}{l}\text { Swofford } \\
\text { Pond }\end{array}$ & $\begin{array}{c}7 / 5 / 07 \\
0: 00 \\
\end{array}$ & 46.49728658 & $\begin{array}{c}- \\
122.4056376\end{array}$ & 238.87 & 241 & Lake & -64.99 & -8.28 & 1.25 & EPA_Corvallis & 10 \\
\hline $\begin{array}{c}17- \\
040 \_7365 \\
\end{array}$ & MMB181 & $\begin{array}{c}8 / 20 / 16 \\
0: 00 \\
\end{array}$ & 46.911352 & -121.657698 & 1889.3 & 1891 & Lake & 100.61 & -12.90 & 2.59 & SPATIAL & 98 \\
\hline $\begin{array}{c}17- \\
040 \_7351\end{array}$ & MMB167 & $\begin{array}{c}8 / 19 / 16 \\
0: 00 \\
\end{array}$ & 46.978325 & -123.883273 & 1.1 & 1 & Stream/River & -27.33 & -3.85 & 3.45 & SPATIAL & 98 \\
\hline 710376 & Swamp & $\begin{array}{c}7 / 17 / 07 \\
0: 00 \\
\end{array}$ & 47.31108363 & $\begin{array}{c}- \\
121.2990598 \\
\end{array}$ & 732.43 & 734 & Lake & -81.33 & -10.68 & 4.09 & EPA_Corvallis & 10 \\
\hline
\end{tabular}




\begin{tabular}{|c|c|c|c|c|c|c|c|c|c|c|c|c|}
\hline $\begin{array}{c}17- \\
040 \_7353\end{array}$ & MMB169 & $\begin{array}{c}8 / 19 / 16 \\
0: 00\end{array}$ & 46.977018 & -123.796332 & 2.5 & 2 & Stream/River & -36.89 & -5.27 & 5.28 & SPATIAL & 98 \\
\hline CK_4021 & $\begin{array}{c}\text { Willapa } \\
\text { River Near } \\
\text { Willapa }\end{array}$ & $\begin{array}{c}5 / 23 / 85 \\
0: 00 \\
\end{array}$ & 46.64999 & -123.6528 & 1.0973 & 7 & Stream/River & -58.9 & -8.75 & 11.10 & USGS & 48 \\
\hline CK_4024 & $\begin{array}{c}\text { Willapa } \\
\text { River Near } \\
\text { Willapa }\end{array}$ & $\begin{array}{c}3 / 6 / 86 \\
0: 00\end{array}$ & 46.64999 & -123.6528 & 1.0973 & 7 & Stream/River & -60.1 & -8.72 & 9.66 & USGS & 48 \\
\hline CK_4020 & $\begin{array}{c}\text { Willapa } \\
\text { River Near } \\
\text { Willapa }\end{array}$ & $\begin{array}{c}3 / 21 / 85 \\
0: 00 \\
\end{array}$ & 46.64999 & -123.6528 & 1.0973 & 7 & Stream/River & -60 & -8.7 & 9.60 & USGS & 48 \\
\hline CK_4025 & $\begin{array}{c}\text { Willapa } \\
\text { River Near } \\
\text { Willapa }\end{array}$ & $\begin{array}{c}5 / 29 / 86 \\
0: 00\end{array}$ & 46.64999 & -123.6528 & 1.0973 & 7 & Stream/River & -58.1 & -8.61 & 10.78 & USGS & 48 \\
\hline CK 4019 & $\begin{array}{l}\text { Willapa } \\
\text { River Near } \\
\text { Willapa }\end{array}$ & $\begin{array}{c}11 / 16 / 84 \\
0: 00\end{array}$ & 46.64999 & -123.6528 & 1.0973 & 7 & Stream/River & -59.5 & -8.55 & 8.90 & USGS & 48 \\
\hline CK_4023 & $\begin{array}{c}\text { Willapa } \\
\text { River Near } \\
\text { Willapa }\end{array}$ & $\begin{array}{c}11 / 15 / 85 \\
0: 00\end{array}$ & 46.64999 & -123.6528 & 1.0973 & 7 & Stream/River & -57 & -8.5 & 11.00 & USGS & 48 \\
\hline CK_4022 & $\begin{array}{c}\text { Willapa } \\
\text { River Near } \\
\text { Willapa }\end{array}$ & $\begin{array}{c}8 / 21 / 85 \\
0: 00 \\
\end{array}$ & 46.64999 & -123.6528 & 1.0973 & 7 & Stream/River & -57.7 & -8.29 & 8.62 & USGS & 48 \\
\hline CK_ 4026 & $\begin{array}{l}\text { Willapa } \\
\text { River Near } \\
\text { Willapa }\end{array}$ & $\begin{array}{c}8 / 28 / 86 \\
0: 00\end{array}$ & 46.64999 & -123.6528 & 1.0973 & 7 & Stream/River & -55.9 & -8 & 8.10 & USGS & 48 \\
\hline CK_4029 & $\begin{array}{c}\text { Chehalis } \\
\text { River At } \\
\text { Porter }\end{array}$ & $\begin{array}{c}1 / 28 / 85 \\
0: 00 \\
\end{array}$ & 46.93804 & -123.3125 & 7.1933 & 9 & Stream/River & -67 & -9.65 & 10.20 & USGS & 48 \\
\hline CK_4035 & $\begin{array}{c}\text { Chehalis } \\
\text { River At } \\
\text { Porter }\end{array}$ & $\begin{array}{c}1 / 23 / 86 \\
0: 00\end{array}$ & 46.93804 & -123.3125 & 7.1933 & 9 & Stream/River & -65.8 & -9.6 & 11.00 & USGS & 48 \\
\hline CK_4036 & $\begin{array}{c}\text { Chehalis } \\
\text { River At } \\
\text { Porter }\end{array}$ & $\begin{array}{c}3 / 24 / 86 \\
0: 00\end{array}$ & 46.93804 & -123.3125 & 7.1933 & 9 & Stream/River & -66.1 & -9.52 & 10.06 & USGS & 48 \\
\hline CK_4030 & $\begin{array}{c}\text { Chehalis } \\
\text { River At } \\
\text { Porter }\end{array}$ & $\begin{array}{c}3 / 18 / 85 \\
0: 00\end{array}$ & 46.93804 & -123.3125 & 7.1933 & 9 & Stream/River & -67 & -9.5 & 9.00 & USGS & 48 \\
\hline CK_4031 & $\begin{array}{l}\text { Chehalis } \\
\text { River At } \\
\text { Porter }\end{array}$ & $\begin{array}{c}5 / 20 / 85 \\
0: 00 \\
\end{array}$ & 46.93804 & -123.3125 & 7.1933 & 9 & Stream/River & -64.5 & -9.5 & 11.50 & USGS & 48 \\
\hline CK_4037 & $\begin{array}{c}\text { Chehalis } \\
\text { River At } \\
\text { Porter }\end{array}$ & $\begin{array}{c}5 / 30 / 86 \\
0: 00\end{array}$ & 46.93804 & -123.3125 & 7.1933 & 9 & Stream/River & -64.3 & -9.48 & 11.54 & USGS & 48 \\
\hline CK 4039 & $\begin{array}{l}\text { Chehalis } \\
\text { River At } \\
\text { Porter }\end{array}$ & $\begin{array}{c}1 / 27 / 87 \\
0: 00\end{array}$ & 46.93804 & -123.3125 & 7.1933 & 9 & Stream/River & -63.5 & -9.36 & 11.38 & USGS & 48 \\
\hline
\end{tabular}




\begin{tabular}{|c|c|c|c|c|c|c|c|c|c|c|c|c|}
\hline CK_ 4028 & $\begin{array}{c}\text { Chehalis } \\
\text { River At } \\
\text { Porter }\end{array}$ & $\begin{array}{c}11 / 16 / 84 \\
0: 00\end{array}$ & 46.93804 & -123.3125 & 7.1933 & 9 & Stream/River & -65.5 & -9.35 & 9.30 & USGS & 48 \\
\hline CK_4027 & $\begin{array}{l}\text { Chehalis } \\
\text { River At } \\
\text { Porter }\end{array}$ & $\begin{array}{c}9 / 20 / 84 \\
0: 00 \\
\end{array}$ & 46.93804 & -123.3125 & 7.1933 & 9 & Stream/River & -64 & -9.35 & 10.80 & USGS & 48 \\
\hline CK_4034 & $\begin{array}{c}\text { Chehalis } \\
\text { River At } \\
\text { Porter }\end{array}$ & $\begin{array}{c}11 / 12 / 85 \\
0: 00 \\
\end{array}$ & 46.93804 & -123.3125 & 7.1933 & 9 & Stream/River & -63.5 & -9.34 & 11.22 & USGS & 48 \\
\hline CK_4033 & $\begin{array}{c}\text { Chehalis } \\
\text { River At } \\
\text { Porter }\end{array}$ & $\begin{array}{c}9 / 23 / 85 \\
0: 00\end{array}$ & 46.93804 & -123.3125 & 7.1933 & 9 & Stream/River & -62.8 & -9.32 & 11.76 & USGS & 48 \\
\hline CK_4040 & $\begin{array}{l}\text { Chehalis } \\
\text { River At } \\
\text { Porter }\end{array}$ & $\begin{array}{c}5 / 6 / 87 \\
0: 00 \\
\end{array}$ & 46.93804 & -123.3125 & 7.1933 & 9 & Stream/River & -64.5 & -9.26 & 9.58 & USGS & 48 \\
\hline CK_4038 & $\begin{array}{c}\text { Chehalis } \\
\text { River At } \\
\text { Porter }\end{array}$ & $\begin{array}{c}7 / 22 / 86 \\
0: 00\end{array}$ & 46.93804 & -123.3125 & 7.1933 & 9 & Stream/River & -63.6 & -9.21 & 10.08 & USGS & 48 \\
\hline CK_ 4032 & $\begin{array}{l}\text { Chehalis } \\
\text { River At } \\
\text { Porter }\end{array}$ & $\begin{array}{c}7 / 22 / 85 \\
0: 00\end{array}$ & 46.93804 & -123.3125 & 7.1933 & 9 & Stream/River & -63.4 & -9.14 & 9.72 & USGS & 48 \\
\hline CK_4042 & $\begin{array}{l}\text { Chehalis } \\
\text { River At } \\
\text { Porter }\end{array}$ & $\begin{array}{c}9 / 10 / 87 \\
0: 00\end{array}$ & 46.93804 & -123.3125 & 7.1933 & 9 & Stream/River & -62.8 & -9.1 & 10.00 & USGS & 48 \\
\hline CK_ 4041 & $\begin{array}{l}\text { Chehalis } \\
\text { River At } \\
\text { Porter }\end{array}$ & $\begin{array}{c}7 / 8 / 87 \\
0: 00\end{array}$ & 46.93804 & -123.3125 & 7.1933 & 9 & Stream/River & -64.2 & -9.07 & 8.36 & USGS & 48 \\
\hline $\begin{array}{c}17- \\
0407354\end{array}$ & MMB170 & $\begin{array}{c}8 / 19 / 16 \\
0: 00\end{array}$ & 46.999313 & -123.492539 & 12.6 & 8 & Stream/River & -59.83 & -8.62 & 9.10 & SPATIAL & 98 \\
\hline $\begin{array}{c}17- \\
040 \quad 7346\end{array}$ & MMB162 & $\begin{array}{c}8 / 18 / 16 \\
0: 00\end{array}$ & 47.467764 & -123.847034 & 68 & 68 & Lake & -72.46 & -10.39 & 10.62 & SPATIAL & 98 \\
\hline $\begin{array}{c}17- \\
040 \quad 7345\end{array}$ & MMB161 & $\begin{array}{c}8 / 18 / 16 \\
0: 00\end{array}$ & 47.464312 & -123.842423 & 90.1 & 94 & Stream/River & -60.79 & -9.04 & 11.52 & SPATIAL & 98 \\
\hline $\begin{array}{c}17- \\
040 \quad 7357\end{array}$ & MMB173 & $\begin{array}{c}8 / 19 / 16 \\
0: 00\end{array}$ & 46.531968 & -122.558116 & 130.5 & 130 & Lake & -77.71 & -10.76 & 8.36 & SPATIAL & 98 \\
\hline 711198 & $\begin{array}{l}\text { Cushman } \\
\text { Lake }\end{array}$ & $\begin{array}{c}9 / 11 / 07 \\
0: 00\end{array}$ & 47.48799465 & 123.2647195 & 225.08 & 222 & Lake & -75.42 & -10.71 & 10.27 & EPA Corvallis & 10 \\
\hline $\begin{array}{c}17- \\
040 \_7358\end{array}$ & MMB174 & $\begin{array}{c}8 / 19 / 16 \\
0: 00\end{array}$ & 46.534867 & -121.794237 & 285.9 & 286 & Stream/River & -96.27 & -13.32 & 10.25 & SPATIAL & 98 \\
\hline $\begin{array}{c}\overline{17-} \\
040 \quad 7369\end{array}$ & MMB185 & $\begin{array}{c}8 / 20 / 16 \\
0: 00\end{array}$ & 47.158447 & -121.65803 & 512 & 515 & Stream/River & -91.66 & -12.70 & 9.94 & SPATIAL & 98 \\
\hline 710819 & $\begin{array}{l}\text { Cle Elum } \\
\text { Lake }\end{array}$ & $\begin{array}{c}8 / 14 / 07 \\
0: 00\end{array}$ & 47.26690206 & -121.094003 & 678.81 & 681 & Lake & -97.19 & -13.10 & 7.64 & EPA_Corvallis & 10 \\
\hline $\begin{array}{c}17- \\
0407363\end{array}$ & MMB179 & $\begin{array}{c}8 / 20 / 16 \\
0: 00\end{array}$ & 46.766528 & -121.789606 & 963.4 & 965 & Stream/River & 106.18 & -14.70 & 11.38 & SPATIAL & 98 \\
\hline $\begin{array}{c}17- \\
040 \quad 7368\end{array}$ & MMB184 & $\begin{array}{c}8 / 20 / 16 \\
0: 00\end{array}$ & 46.902765 & -121.629282 & 1245 & 1245 & Stream/River & 120.45 & -16.34 & 10.24 & SPATIAL & 98 \\
\hline $\begin{array}{c}17- \\
040 \quad 7364\end{array}$ & MMB180 & $\begin{array}{c}8 / 20 / 16 \\
0: 00\end{array}$ & 46.768778 & -121.731565 & 1481.9 & 1482 & Lake & -89.33 & -12.11 & 7.53 & SPATIAL & 98 \\
\hline
\end{tabular}




\begin{tabular}{|c|c|c|c|c|c|c|c|c|c|c|c|c|}
\hline $\begin{array}{c}17- \\
040 \_7362 \\
\end{array}$ & MMB178 & $\begin{array}{c}8 / 19 / 16 \\
0: 00\end{array}$ & 46.790215 & -121.726761 & 1599.6 & 1600 & Stream/River & -94.38 & -12.93 & 9.05 & SPATIAL & 98 \\
\hline $\begin{array}{c}\overline{17-} \\
040 \_7361\end{array}$ & MMB177 & $\begin{array}{c}8 / 19 / 16 \\
0: 00 \\
\end{array}$ & 46.791536 & -121.732688 & 1702.7 & 1704 & Stream/River & -93.15 & -12.93 & 10.28 & SPATIAL & 98 \\
\hline $\begin{array}{c}17- \\
040 \_7367\end{array}$ & MMB183 & $\begin{array}{c}8 / 20 / 16 \\
0: 00\end{array}$ & 46.919123 & -121.665766 & 2049.9 & 2050 & Lake & $10 \overline{1.98}$ & -13.68 & 7.48 & SPATIAL & 98 \\
\hline $\begin{array}{c}\text { NRSA0809- } \\
1911\end{array}$ & $\begin{array}{c}\text { Rattlesnake } \\
\text { Creek }\end{array}$ & $\begin{array}{c}9 / 17 / 08 \\
0: 00 \\
\end{array}$ & 46.79931424 & $\begin{array}{c}- \\
121.0911253 \\
\end{array}$ & & 859 & Stream/River & $\begin{array}{c}- \\
108.07 \\
\end{array}$ & -14.63 & 8.96 & EPA & 165 \\
\hline $\begin{array}{l}\text { NRSA0809- } \\
1914\end{array}$ & $\begin{array}{c}\text { Cle Elum } \\
\text { River }\end{array}$ & $\begin{array}{c}8 / 18 / 09 \\
0: 00\end{array}$ & 47.42374197 & $\begin{array}{c}- \\
121.0764659\end{array}$ & & 789 & Stream/River & $\begin{array}{c}- \\
105.51\end{array}$ & -14.58 & 11.11 & EPA & 165 \\
\hline CK_4080 & $\begin{array}{l}\text { Puyallup } \\
\text { River At } \\
\text { Puyallup }\end{array}$ & $\begin{array}{c}8 / 5 / 86 \\
0: 00\end{array}$ & 47.21444 & -122.3403 & & 7 & Stream/River & 102.00 & -14.14 & 11.12 & USGS & 48 \\
\hline CK_4076 & $\begin{array}{l}\text { Puyallup } \\
\text { River At } \\
\text { Puyallup }\end{array}$ & $\begin{array}{c}8 / 19 / 85 \\
0: 00 \\
\end{array}$ & 47.21444 & -122.3403 & & 7 & Stream/River & 103.50 & -14.13 & 9.54 & USGS & 48 \\
\hline CK_4081 & $\begin{array}{l}\text { Puyallup } \\
\text { River At } \\
\text { Puyallup }\end{array}$ & $\begin{array}{c}8 / 26 / 87 \\
0: 00\end{array}$ & 47.21444 & -122.3403 & & 7 & Stream/River & 100.20 & -13.94 & 11.32 & USGS & 48 \\
\hline CK_4075 & $\begin{array}{l}\text { Puyallup } \\
\text { River At } \\
\text { Puyallup }\end{array}$ & $\begin{array}{c}5 / 13 / 85 \\
0: 00 \\
\end{array}$ & 47.21444 & -122.3403 & & 7 & Stream/River & -84.90 & -12.20 & 12.70 & USGS & 48 \\
\hline $\begin{array}{c}\text { NRSA0809- } \\
1885\end{array}$ & $\begin{array}{l}\text { Rushing } \\
\text { Water } \\
\text { Creek }\end{array}$ & $\begin{array}{c}9 / 15 / 09 \\
0: 00 \\
\end{array}$ & 46.896298 & $\begin{array}{c}- \\
121.9899991\end{array}$ & & 670 & Stream/River & -85.00 & -11.86 & 9.88 & EPA & 165 \\
\hline CK_4073 & $\begin{array}{l}\text { Puyallup } \\
\text { River At } \\
\text { Puyallup }\end{array}$ & $\begin{array}{c}11 / 26 / 84 \\
0: 00 \\
\end{array}$ & 47.21444 & -122.3403 & & 7 & Stream/River & -85.00 & -11.65 & 8.20 & USGS & 48 \\
\hline CK_4074 & $\begin{array}{l}\text { Puyallup } \\
\text { River At } \\
\text { Puyallup }\end{array}$ & $\begin{array}{c}3 / 4 / 85 \\
0: 00\end{array}$ & 47.21444 & -122.3403 & & 7 & Stream/River & -85.00 & -11.60 & 7.80 & USGS & 48 \\
\hline CK_4078 & $\begin{array}{l}\text { Puyallup } \\
\text { River At } \\
\text { Puyallup }\end{array}$ & $\begin{array}{c}2 / 19 / 86 \\
0: 00 \\
\end{array}$ & 47.21444 & -122.3403 & & 7 & Stream/River & -82.50 & -11.54 & 9.82 & USGS & 48 \\
\hline CK_4077 & $\begin{array}{l}\text { Puyallup } \\
\text { River At } \\
\text { Puyallup }\end{array}$ & $\begin{array}{c}11 / 19 / 85 \\
0: 00\end{array}$ & 47.21444 & -122.3403 & & 7 & Stream/River & -81.50 & -11.50 & 10.50 & USGS & 48 \\
\hline CK_4079 & $\begin{array}{l}\text { Puyallup } \\
\text { River At } \\
\text { Puyallup }\end{array}$ & $\begin{array}{c}5 / 19 / 86 \\
0: 00 \\
\end{array}$ & 47.21444 & -122.3403 & & 7 & Stream/River & -80.30 & -11.24 & 9.62 & USGS & 48 \\
\hline $\begin{array}{l}\text { NRSA0809- } \\
1896 \\
\end{array}$ & $\begin{array}{l}\text { Kiona } \\
\text { Creek }\end{array}$ & $\begin{array}{c}7 / 29 / 09 \\
0: 00 \\
\end{array}$ & 46.5377567 & $\begin{array}{c}- \\
122.0414352\end{array}$ & & 316 & Stream/River & -79.26 & -11.19 & 10.23 & EPA & 165 \\
\hline $\begin{array}{l}\text { NRSA0809- } \\
1890 \\
\end{array}$ & $\begin{array}{l}\text { Medicine } \\
\text { Creek }\end{array}$ & $\begin{array}{c}7 / 30 / 09 \\
0: 00 \\
\end{array}$ & 47.05149107 & $\begin{array}{c}- \\
122.7212905 \\
\end{array}$ & & 4 & Stream/River & -70.33 & -9.59 & 6.39 & EPA & 165 \\
\hline $\begin{array}{c}\text { NRSA0809- } \\
1913 \\
\end{array}$ & $\begin{array}{c}\text { East Fork } \\
\text { Hoquiam } \\
\text { River }\end{array}$ & $\begin{array}{c}7 / 28 / 09 \\
0: 00 \\
\end{array}$ & 47.06727475 & $\begin{array}{c}- \\
123.8236035 \\
\end{array}$ & & 17 & Stream/River & -55.29 & -8.26 & 10.78 & EPA & 165 \\
\hline $\begin{array}{l}\text { NRSA0809- } \\
1919 \\
\end{array}$ & $\begin{array}{l}\text { Wishkah } \\
\text { River }\end{array}$ & $\begin{array}{c}10 / 6 / 09 \\
0: 00 \\
\end{array}$ & 47.13550231 & $\begin{array}{c}- \\
123.7768693 \\
\end{array}$ & & 30 & Stream/River & -56.79 & -8.14 & 8.36 & EPA & 165 \\
\hline
\end{tabular}




\begin{tabular}{|c|c|c|c|c|c|c|c|c|c|c|c|}
\hline $\begin{array}{c}\text { NRSA0809- } \\
1898\end{array}$ & $\begin{array}{c}\text { Unnamed } \\
\text { South of } \\
\text { Oakville }\end{array}$ & $\begin{array}{c}9 / 9 / 09 \\
0: 00\end{array}$ & 46.8375725 & 123.3862738 & & & & & & & \\
\hline $\begin{array}{c}\text { NRSA0809- } \\
1915\end{array}$ & $\begin{array}{c}\text { Williams } \\
\text { Creek }\end{array}$ & $\begin{array}{c}10 / 11 / 09 \\
0: 00\end{array}$ & 46.53201333 & 123.8270244 & & Stream/River & -57.26 & -8.12 & 7.67 & EPA & 165 \\
\hline
\end{tabular}

Appendix D. Meteoric waters used in the determination for the leeward lapse rate (WaterIsotopes, 2020; IAEA, 2020).

\begin{tabular}{|c|c|c|c|c|c|c|c|c|c|c|c|c|}
\hline Sample ID & Site Name & $\begin{array}{l}\text { Collection } \\
\text { Date }\end{array}$ & Latitude & $\begin{array}{c}\text { Longitud } \\
\mathrm{e}\end{array}$ & $\begin{array}{c}\text { Collectio } \\
n \\
\text { Elevation } \\
\text { (mabsl) }\end{array}$ & $\begin{array}{c}\text { Collectio } \\
n \\
\text { Elevation } \\
\text { from } \\
\text { Google } \\
\text { Earth (m) }\end{array}$ & Type & $\begin{array}{l}\delta D \\
\text { (per } \\
\text { mille) }\end{array}$ & $\begin{array}{c}\delta^{18} O \\
\text { (per } \\
\text { mille) }\end{array}$ & d & $\begin{array}{l}\text { WI Analysis } \\
\text { Source }\end{array}$ & $\begin{array}{l}\text { Projec } \\
\text { t ID }\end{array}$ \\
\hline 710866 & Grimes & $\begin{array}{c}8 / 16 / 07 \\
0: 00 \\
\end{array}$ & $\begin{array}{c}47.728697 \\
1 \\
\end{array}$ & -119.5926 & 559.3 & 559 & Lake & -73.58 & -5.10 & -32.78 & $\begin{array}{c}\text { EPA_Corvalli } \\
\text { s }\end{array}$ & 10 \\
\hline 711100 & Medical Lake & $\begin{array}{c}8 / 30 / 07 \\
0: 00 \\
\end{array}$ & $\begin{array}{c}47.570687 \\
2 \\
\end{array}$ & $\begin{array}{c}- \\
117.68899 \\
\end{array}$ & 731.2 & 730 & Lake & -61.57 & -4.19 & -28.05 & $\begin{array}{c}\text { EPA_Corvalli } \\
\mathrm{s}\end{array}$ & 10 \\
\hline 711242 & $\begin{array}{l}\text { Saddle Mountain } \\
\text { Lake }\end{array}$ & $\begin{array}{c}9 / 13 / 07 \\
0: 00\end{array}$ & $\begin{array}{c}46.693467 \\
2\end{array}$ & $119 . \overline{-}-$ & 149.1 & 149 & Lake & $\begin{array}{c}- \\
111.4 \\
3 \\
\end{array}$ & -13.57 & -2.89 & $\underset{\mathrm{s}}{\text { EPA_Corvalli }}$ & 10 \\
\hline 711132 & Moses Lake & $\begin{array}{c}9 / 4 / 07 \\
0: 00\end{array}$ & $\begin{array}{c}47.184414 \\
4\end{array}$ & 119.36398 & 320.1 & 318 & Lake & $\begin{array}{c}- \\
117.4 \\
8\end{array}$ & -14.58 & -0.82 & $\underset{s}{E P A \_C o r v a l l i ~}$ & 10 \\
\hline CK_4224 & $\begin{array}{c}\text { Columbia R At } \\
\text { Vernita Br Nr } \\
\text { Priest Rpds Dm }\end{array}$ & $\begin{array}{c}9 / 30 / 85 \\
0: 00\end{array}$ & 46.63999 & -119.7317 & & 121 & $\begin{array}{c}\text { Stream/Rive } \\
r\end{array}$ & $\begin{array}{c}132.6 \\
0 \\
\end{array}$ & -16.74 & 1.32 & USGS & 48 \\
\hline 711214 & Red Rock Lake & $\begin{array}{c}9 / 12 / 07 \\
0: 00\end{array}$ & $\begin{array}{c}46.871389 \\
4\end{array}$ & $\begin{array}{c}- \\
119.57087\end{array}$ & 211 & 210 & Lake & $\begin{array}{c}- \\
123.0 \\
2\end{array}$ & -15.75 & 2.99 & $\underset{S}{E P A \_C o r v a l l i ~}$ & 10 \\
\hline $\begin{array}{l}\text { NRSA0809 } \\
-1906\end{array}$ & $\begin{array}{c}\text { Snake River } \\
\text { near Granite } \\
\text { Dam }\end{array}$ & $\begin{array}{c}9 / 25 / 09 \\
0: 00\end{array}$ & $\begin{array}{c}46.655985 \\
3\end{array}$ & $\begin{array}{c}- \\
117.41411\end{array}$ & & 225 & $\underset{r}{\text { Stream/Rive }}$ & $\begin{array}{c}- \\
122.3 \\
0\end{array}$ & -15.83 & 4.37 & EPA & 165 \\
\hline CK_4225 & $\begin{array}{l}\text { Columbia R At } \\
\text { Vernita Br Nr } \\
\text { Priest Rpds Dm }\end{array}$ & $\begin{array}{c}12 / 17 / 85 \\
0: 00\end{array}$ & 46.63999 & -119.7317 & & 121 & $\underset{r}{\text { Stream/Rive }}$ & $\begin{array}{c}- \\
132.3 \\
0\end{array}$ & -17.17 & 5.06 & USGS & 48 \\
\hline CK_4234 & $\begin{array}{l}\text { Columbia R At } \\
\text { Vernita Br Nr } \\
\text { Priest Rpds Dm }\end{array}$ & $\begin{array}{c}5 / 19 / 87 \\
0: 00\end{array}$ & 46.63999 & -119.7317 & & 121 & $\underset{r}{\text { Stream/Rive }}$ & $\begin{array}{c}- \\
126.0 \\
0\end{array}$ & -16.54 & 6.32 & USGS & 48 \\
\hline CK_4220 & $\begin{array}{l}\text { Columbia R At } \\
\text { Vernita Br Nr } \\
\text { Priest Rpds Dm }\end{array}$ & $\begin{array}{c}1 / 22 / 85 \\
0: 00\end{array}$ & 46.63999 & -119.7317 & & 121 & $\underset{r}{\text { Stream/Rive }}$ & $\begin{array}{c}- \\
134.0 \\
0 \\
\end{array}$ & -17.55 & 6.40 & USGS & 48 \\
\hline $\begin{array}{c}17- \\
040 \_7388\end{array}$ & MMB204 & $\begin{array}{c}8 / 22 / 16 \\
0: 00\end{array}$ & 47.425198 & -120.3057 & 188.6 & 188 & $\underset{r}{\text { Stream/Rive }}$ & $\begin{array}{c}- \\
128.3 \\
7\end{array}$ & -16.86 & 6.48 & SPATIAL & 98 \\
\hline
\end{tabular}




\begin{tabular}{|c|c|c|c|c|c|c|c|c|c|c|c|c|}
\hline CK_4231 & $\begin{array}{l}\text { Columbia R At } \\
\text { Vernita Br Nr } \\
\text { Priest Rpds Dm }\end{array}$ & $\begin{array}{c}11 / 12 / 86 \\
0: 00\end{array}$ & 46.63999 & -119.7317 & & 121 & $\underset{r}{\text { Stream/Rive }}$ & $\begin{array}{c}- \\
131.5 \\
0\end{array}$ & -17.26 & 6.58 & USGS & 48 \\
\hline CK_4253 & $\begin{array}{c}\text { Yakima River } \\
\text { Abv Ahtanum Cr } \\
\text { At Union Gap }\end{array}$ & $\begin{array}{c}9 / 17 / 85 \\
0: 00\end{array}$ & 46.53444 & -120.4661 & 274.3 & 289 & $\underset{r}{\text { Stream/Rive }}$ & $\begin{array}{c}- \\
100.6 \\
0\end{array}$ & -13.41 & 6.68 & USGS & 48 \\
\hline CK_4262 & $\begin{array}{c}\text { Yakima River } \\
\text { Abv Ahtanum Cr } \\
\text { At Union Gap }\end{array}$ & $\begin{array}{c}8 / 11 / 87 \\
0: 00\end{array}$ & 46.53444 & -120.4661 & 274.3 & 289 & $\underset{r}{\text { Stream/Rive }}$ & -97.60 & -13.05 & 6.80 & USGS & 48 \\
\hline CK_4263 & $\begin{array}{c}\text { Yakima River } \\
\text { Abv Ahtanum Cr } \\
\text { At Union Gap }\end{array}$ & $\begin{array}{c}9 / 10 / 87 \\
0: 00\end{array}$ & 46.53444 & -120.4661 & 274.3 & 289 & $\underset{r}{\text { Stream/Rive }}$ & -98.00 & -13.11 & 6.88 & USGS & 48 \\
\hline CK_4218 & $\begin{array}{l}\text { Columbia R At } \\
\text { Vernita Br Nr } \\
\text { Priest Rpds Dm }\end{array}$ & $\begin{array}{c}9 / 11 / 84 \\
0: 00\end{array}$ & 46.63999 & -119.7317 & & 121 & $\underset{r}{\text { Stream/Rive }}$ & $\begin{array}{c}- \\
129.5 \\
0\end{array}$ & -17.05 & 6.90 & USGS & 48 \\
\hline CK_4221 & $\begin{array}{l}\text { Columbia R At } \\
\text { Vernita } \mathrm{Br} \mathrm{Nr} \\
\text { Priest Rpds Dm }\end{array}$ & $\begin{array}{c}3 / 26 / 85 \\
0: 00\end{array}$ & 46.63999 & -119.7317 & & 121 & $\underset{r}{\text { Stream/Rive }}$ & $\begin{array}{c}- \\
137.5 \\
0 \\
\end{array}$ & -18.05 & 6.90 & USGS & 48 \\
\hline $\begin{array}{c}17- \\
040 \_7324\end{array}$ & MMB140 & $\begin{array}{c}8 / 12 / 16 \\
0: 00\end{array}$ & 46.941122 & $119 . \overline{9} 8422$ & 175.2 & 175 & Lake & $\begin{array}{c}- \\
128.9 \\
1\end{array}$ & -16.99 & 6.97 & SPATIAL & 98 \\
\hline CK_4254 & $\begin{array}{c}\text { Yakima River } \\
\text { Abv Ahtanum Cr } \\
\text { At Union Gap }\end{array}$ & $\begin{array}{c}11 / 5 / 85 \\
0: 00\end{array}$ & 46.53444 & -120.4661 & 274.3 & 289 & $\underset{r}{\text { Stream/Rive }}$ & -99.90 & -13.38 & 7.14 & USGS & 48 \\
\hline CK_4226 & $\begin{array}{l}\text { Columbia R At } \\
\text { Vernita } \mathrm{Br} \mathrm{Nr} \\
\text { Priest Rpds Dm }\end{array}$ & $\begin{array}{c}1 / 21 / 86 \\
0: 00\end{array}$ & 46.63999 & -119.7317 & & 121 & $\underset{r}{\text { Stream/Rive }}$ & $\begin{array}{c}- \\
133.3 \\
0\end{array}$ & -17.56 & 7.18 & USGS & 48 \\
\hline CK_4255 & $\begin{array}{c}\text { Yakima River } \\
\text { Abv Ahtanum Cr } \\
\text { At Union Gap }\end{array}$ & $\begin{array}{c}1 / 27 / 86 \\
0: 00\end{array}$ & 46.53444 & -120.4661 & 274.3 & 289 & $\underset{r}{\text { Stream/Rive }}$ & $\begin{array}{c}- \\
105.7 \\
0\end{array}$ & -14.13 & 7.34 & USGS & 48 \\
\hline CK_4219 & $\begin{array}{c}\text { Columbia R At } \\
\text { Vernita Br Nr } \\
\text { Priest Rpds Dm }\end{array}$ & $\begin{array}{c}11 / 14 / 84 \\
0: 00\end{array}$ & 46.63999 & -119.7317 & & 121 & $\underset{r}{\text { Stream/Rive }}$ & $\begin{array}{c}- \\
131.0 \\
0\end{array}$ & -17.30 & 7.40 & USGS & 48 \\
\hline CK_4229 & $\begin{array}{l}\text { Columbia R At } \\
\text { Vernita Br Nr } \\
\text { Priest Rpds Dm }\end{array}$ & $\begin{array}{c}7 / 21 / 86 \\
0: 00\end{array}$ & 46.63999 & -119.7317 & & 121 & $\underset{r}{\text { Stream/Rive }}$ & $\begin{array}{c}- \\
127.5 \\
0\end{array}$ & -16.88 & 7.54 & USGS & 48 \\
\hline CK_4233 & $\begin{array}{l}\text { Columbia R At } \\
\text { Vernita } \mathrm{Br} \mathrm{Nr} \\
\text { Priest Rpds Dm }\end{array}$ & $\begin{array}{c}3 / 10 / 87 \\
0: 00\end{array}$ & 46.63999 & -119.7317 & & 121 & $\underset{r}{\text { Stream/Rive }}$ & $\begin{array}{c}133.8 \\
0\end{array}$ & -17.67 & 7.56 & USGS & 48 \\
\hline CK_4227 & $\begin{array}{l}\text { Columbia R At } \\
\text { Vernita } \mathrm{Br} \mathrm{Nr} \\
\text { Priest Rpds Dm }\end{array}$ & $\begin{array}{c}3 / 12 / 86 \\
0: 00\end{array}$ & 46.63999 & -119.7317 & & 121 & $\underset{r}{\text { Stream/Rive }}$ & $\begin{array}{c}- \\
133.7 \\
0\end{array}$ & -17.66 & 7.58 & USGS & 48 \\
\hline CK_4230 & $\begin{array}{l}\text { Columbia R At } \\
\text { Vernita } \mathrm{Br} \mathrm{Nr} \\
\text { Priest Rpds Dm }\end{array}$ & $\begin{array}{c}9 / 25 / 86 \\
0: 00\end{array}$ & 46.63999 & -119.7317 & & 121 & $\underset{r}{\text { Stream/Rive }}$ & $\begin{array}{c}- \\
132.4 \\
0\end{array}$ & -17.50 & 7.60 & USGS & 48 \\
\hline CK_4250 & $\begin{array}{l}\text { Yakima River } \\
\text { Abv Ahtanum Cr } \\
\text { At Union Gap }\end{array}$ & $\begin{array}{c}3 / 13 / 85 \\
0: 00\end{array}$ & 46.53444 & -120.4661 & 274.3 & 289 & $\underset{r}{\text { Stream/Rive }}$ & $\begin{array}{c}- \\
106.0 \\
0\end{array}$ & -14.20 & 7.60 & USGS & 48 \\
\hline
\end{tabular}




\begin{tabular}{|c|c|c|c|c|c|c|c|c|c|c|c|c|}
\hline CK_4236 & $\begin{array}{l}\text { Columbia R At } \\
\text { Vernita Br Nr } \\
\text { Priest Rpds Dm }\end{array}$ & $\begin{array}{c}9 / 2 / 87 \\
0: 00\end{array}$ & 46.63999 & -119.7317 & & 121 & $\underset{r}{\text { Stream/Rive }}$ & $\begin{array}{c}- \\
130.3 \\
0\end{array}$ & -17.25 & 7.70 & USGS & 48 \\
\hline CK_4232 & $\begin{array}{l}\text { Columbia R At } \\
\text { Vernita Br Nr } \\
\text { Priest Rpds Dm }\end{array}$ & $\begin{array}{c}1 / 21 / 87 \\
0: 00\end{array}$ & 46.63999 & -119.7317 & & 121 & $\underset{r}{\text { Stream/Rive }}$ & $\begin{array}{c}- \\
130.8 \\
0 \\
\end{array}$ & -17.35 & 8.00 & USGS & 48 \\
\hline CK_4258 & $\begin{array}{c}\text { Yakima River } \\
\text { Abv Ahtanum Cr } \\
\text { At Union Gap }\end{array}$ & $\begin{array}{c}11 / 5 / 86 \\
0: 00\end{array}$ & 46.53444 & -120.4661 & 274.3 & 289 & $\underset{r}{\text { Stream/Rive }}$ & $\begin{array}{c}- \\
102.3 \\
0\end{array}$ & -13.79 & 8.02 & USGS & 48 \\
\hline CK_4235 & $\begin{array}{l}\text { Columbia R At } \\
\text { Vernita Br Nr } \\
\text { Priest Rpds Dm }\end{array}$ & $\begin{array}{c}7 / 7 / 87 \\
0: 00\end{array}$ & 46.63999 & -119.7317 & & 121 & $\underset{r}{\text { Stream/Rive }}$ & $\begin{array}{c}- \\
125.8 \\
0\end{array}$ & -16.73 & 8.04 & USGS & 48 \\
\hline CK_4222 & $\begin{array}{l}\text { Columbia R At } \\
\text { Vernita Br Nr } \\
\text { Priest Rpds Dm }\end{array}$ & $\begin{array}{c}5 / 28 / 85 \\
0: 00\end{array}$ & 46.63999 & -119.7317 & & 121 & $\underset{r}{\text { Stream/Rive }}$ & $\begin{array}{c}- \\
126.0 \\
0\end{array}$ & -16.76 & 8.08 & USGS & 48 \\
\hline $\begin{array}{c}17- \\
040 \_7387\end{array}$ & MMB203 & $\begin{array}{c}8 / 22 / 16 \\
0: 00\end{array}$ & 47.458426 & -120.3326 & 189.1 & 189 & $\underset{r}{\text { Stream/Rive }}$ & $\begin{array}{c}- \\
106.1 \\
4\end{array}$ & -14.28 & 8.12 & SPATIAL & 98 \\
\hline CK_4223 & $\begin{array}{l}\text { Columbia R At } \\
\text { Vernita Br Nr } \\
\text { Priest Rpds Dm }\end{array}$ & $\begin{array}{c}\text { 7/29/85 } \\
0: 00\end{array}$ & 46.63999 & -119.7317 & & 121 & $\underset{r}{\text { Stream/Rive }}$ & $\begin{array}{c}126.9 \\
0 \\
\end{array}$ & -16.88 & 8.14 & USGS & 48 \\
\hline CK_4248 & $\begin{array}{c}\text { Yakima River } \\
\text { Abv Ahtanum Cr } \\
\text { At Union Gap }\end{array}$ & $\begin{array}{c}11 / 8 / 84 \\
0: 00\end{array}$ & 46.53444 & -120.4661 & 274.3 & 289 & $\begin{array}{c}\text { Stream/Rive } \\
r\end{array}$ & $\begin{array}{c}- \\
103.0 \\
0\end{array}$ & -13.90 & 8.20 & USGS & 48 \\
\hline $\begin{array}{c}17- \\
040 \_7327 \\
\end{array}$ & MMB143 & $\begin{array}{c}8 / 12 / 16 \\
0: 00\end{array}$ & 46.978086 & 120.56742 & 458.2 & 456 & $\begin{array}{c}\text { Stream/Rive } \\
\mathrm{r}\end{array}$ & -94.91 & -12.96 & 8.73 & SPATIAL & 98 \\
\hline CK_4261 & $\begin{array}{c}\text { Yakima River } \\
\text { Abv Ahtanum Cr } \\
\text { At Union Gap }\end{array}$ & $\begin{array}{c}\text { 5/14/87 } \\
0: 00\end{array}$ & 46.53444 & -120.4661 & 274.3 & 289 & $\begin{array}{c}\text { Stream/Rive } \\
\mathrm{r}\end{array}$ & $\begin{array}{c}- \\
103.9 \\
0 \\
\end{array}$ & -14.08 & 8.74 & USGS & 48 \\
\hline CK_4228 & $\begin{array}{l}\text { Columbia R At } \\
\text { Vernita Br Nr } \\
\text { Priest Rpds Dm }\end{array}$ & $\begin{array}{c}5 / 27 / 86 \\
0: 00\end{array}$ & 46.63999 & -119.7317 & & 121 & $\underset{r}{\text { Stream/Rive }}$ & $\begin{array}{c}- \\
125.3 \\
0\end{array}$ & -16.76 & 8.78 & USGS & 48 \\
\hline CK_4249 & $\begin{array}{c}\text { Yakima River } \\
\text { Abv Ahtanum Cr } \\
\text { At Union Gap }\end{array}$ & $\begin{array}{c}1 / 8 / 85 \\
0: 00\end{array}$ & 46.53444 & -120.4661 & 274.3 & 289 & $\underset{r}{\text { Stream/Rive }}$ & $\begin{array}{c}103.5 \\
0 \\
\end{array}$ & -14.05 & 8.90 & USGS & 48 \\
\hline CK_4257 & $\begin{array}{c}\text { Yakima River } \\
\text { Abv Ahtanum Cr } \\
\text { At Union Gap }\end{array}$ & $\begin{array}{c}9 / 22 / 86 \\
0: 00\end{array}$ & 46.53444 & -120.4661 & 274.3 & 289 & $\underset{r}{\text { Stream/Rive }}$ & -98.80 & -13.48 & 9.04 & USGS & 48 \\
\hline CK_4259 & $\begin{array}{c}\text { Yakima River } \\
\text { Abv Ahtanum Cr } \\
\text { At Union Gap }\end{array}$ & $\begin{array}{c}2 / 6 / 87 \\
0: 00\end{array}$ & 46.53444 & -120.4661 & 274.3 & 289 & $\underset{r}{\text { Stream/Rive }}$ & $\begin{array}{c}- \\
103.4 \\
0 \\
\end{array}$ & -14.06 & 9.08 & USGS & 48 \\
\hline CK_4260 & $\begin{array}{c}\text { Yakima River } \\
\text { Abv Ahtanum Cr } \\
\text { At Union Gap }\end{array}$ & $\begin{array}{c}3 / 25 / 87 \\
0: 00\end{array}$ & 46.53444 & -120.4661 & 274.3 & 289 & $\begin{array}{c}\text { Stream/Rive } \\
r\end{array}$ & $\begin{array}{c}- \\
104.2 \\
0\end{array}$ & -14.16 & 9.08 & USGS & 48 \\
\hline CK_4256 & $\begin{array}{c}\text { Yakima River } \\
\text { Abv Ahtanum Cr } \\
\text { At Union Gap }\end{array}$ & $\begin{array}{c}5 / 10 / 86 \\
0: 00\end{array}$ & 46.53444 & -120.4661 & 274.3 & 289 & $\underset{r}{\text { Stream/Rive }}$ & $\begin{array}{c}- \\
103.7 \\
0\end{array}$ & -14.24 & 10.22 & USGS & 48 \\
\hline
\end{tabular}




\begin{tabular}{|c|c|c|c|c|c|c|c|c|c|c|c|c|}
\hline CK_4252 & $\begin{array}{c}\text { Yakima River } \\
\text { Abv Ahtanum Cr } \\
\text { At Union Gap }\end{array}$ & $\begin{array}{c}\text { 7/15/85 } \\
0: 00\end{array}$ & 46.53444 & -120.4661 & 274.3 & 289 & $\underset{r}{\text { Stream/Rive }}$ & $\begin{array}{c}- \\
100.6 \\
0 \\
\end{array}$ & -13.98 & 11.24 & USGS & 48 \\
\hline CK_4251 & $\begin{array}{c}\text { Yakima River } \\
\text { Abv Ahtanum Cr } \\
\text { At Union Gap }\end{array}$ & $\begin{array}{c}5 / 8 / 85 \\
0: 00\end{array}$ & 46.53444 & -120.4661 & 274.3 & 289 & $\underset{r}{\text { Stream/Rive }}$ & $\begin{array}{c}- \\
104.8 \\
0\end{array}$ & -14.53 & 11.44 & USGS & 48 \\
\hline CK_4247 & $\begin{array}{c}\text { Yakima River } \\
\text { Abv Ahtanum Cr } \\
\text { At Union Gap }\end{array}$ & $\begin{array}{c}9 / 11 / 84 \\
0: 00\end{array}$ & 46.53444 & -120.4661 & 274.3 & 289 & $\underset{r}{\text { Stream/Rive }}$ & $\begin{array}{c}- \\
100.0 \\
0\end{array}$ & -13.95 & 11.60 & USGS & 48 \\
\hline
\end{tabular}

